\title{
STATE OF ALABKA
}

Willian A. Egan,- Governor

DEPARTMENT OF NATURAL RESOURCES

Phil R. Holdsworth - Commiseloner

DIVISION OF MINES AND MINERALS

James A. Williams - Director

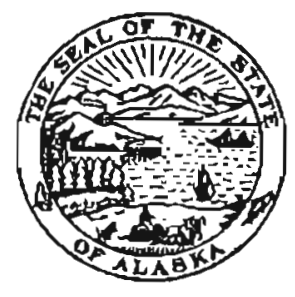

GEOCHEMICAI REPORT NO. 6

Geochemical Investigations of selected

Areag in Southeastern Alaska, 1964 and 1965

By

C.F. Herbert and W.H. Race

Juneau, Alaska

December 1965 
Location Map

General

Sampling and Analyses

Interpretation of Results 4

Prospecting Suggestions 5

Abbreviations

SKAGWAY

Including Table and Map 15

GLACIER POINT 19

Including Table and Maps 21

ST. JAMES AND WILIIAM HENRY BAYS 25

$\begin{array}{ll}\text { Including Table } & 27\end{array}$

Map in Pocket

BERNERS BAY 28

Including Table and Maps 29

TAKU RIVBR

Including Map 32

MANSFIELD PENINSULA

Including Table and Map 35

TENAKEE INLET

Including Table 39

Map in Pocket

KELP BAY

Incluaing Table

43

Map in Pocket

PYBUS AND GAMBIER BAYS

Including Table $\quad 51$

Map in Pocket

STIKINE RIVER

59

Including Map

60 
TABLE OF CONTENTS (Continued)

RATZ HARBOR AND COFFMAN COVE

61

Including Tables and Maps

63

KINA COVE

65

Including Table and Map

66 
GEOCHEMICAL INVESTIGATIONS OF SELECTED AREAS

IN SOUTHEASTERN AIASKA, $1964 \& 1965$

By

C. F. Herbert and W. H. Race

\section{SUMMARY}

Southeastern Alaska, comprising some 40,000 square miles, contains about 7 per cent of the total area of the state, but its past total mine production of metals is equal to 17 per cent of the total production from the entire state. In percentages of Alaskan production, Southeastern Alagka has produced 22 per cent of the gold, 15 per cent of the silver, 100 per cent of the palladium, 3 per cent of the copper, 95 per cent of the lead and 100 per cent of the uranium. Total value of Southeastern Alaska's metal production, at present prices, is about $\$ 250$ million.

Although the area is widely mineralized, very many parts of it have had little or no prospecting. Exposures along the beaches and streambeds, and on cliffs and ridges have been examined, but the major portion of the land area, which is usually covered with dense forest growth. has received only scanty attention. It is believed that geochemical testing of stream sediments in the covered areas will serve, along with geological information in available publications, to direct prospectors to specific localities that have better-than-average chances of containing valuable ore bodies.

In this report we recommend five areas for detailed prospecting and several others that deserve additional reconnaissance.

The locations of areas investigated are shown on the Iocation Map as follows:

1. Skagway

2. Glacier Point

3. St. James and William Henry Bays

4. Berners Bay

5. Taku River

6. Mansfield Peninsula
7. Tenakee Inlet

8. Kelp Bay

9. Pybus and Gambier Bays

10. Stikine River

11. Ratz Harbor and Coffman Cove

12. Kina Cove 


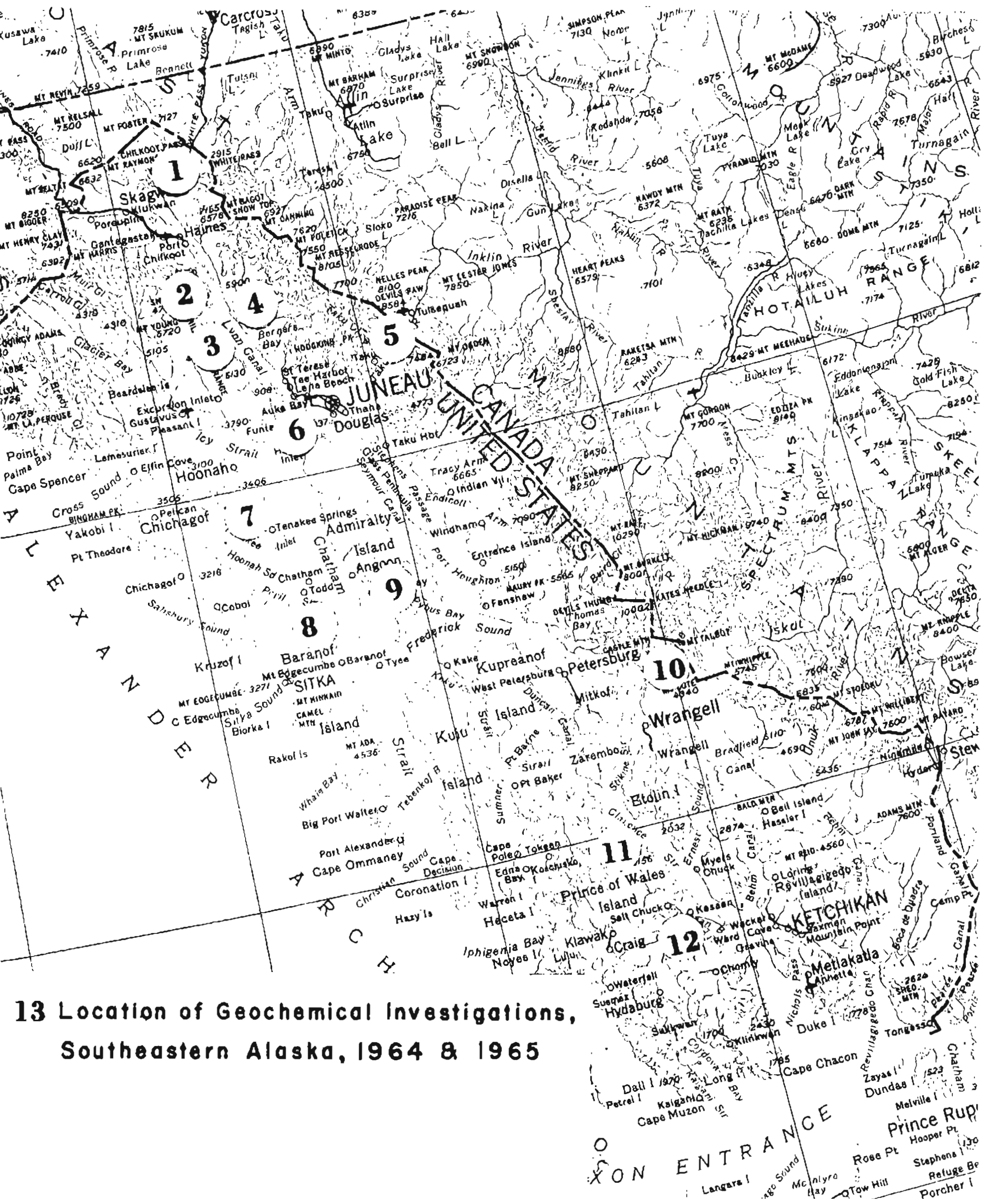




\section{INIRODUCTION}

Gereral

This report. first published in November of 1964, covered the 1964 geochemical investigations of stream sediments in portions of Alaska. The 1964 report is axhausted, so it has been rewritten here and includes work done in 1965. The larger number of analyses now available has caused some changes in intexpretation.

Field work was done by W.H. Race, State Mining Engineer for Southeastern Aliaskn, assisted at times by C.F. Herbert and steven M. Iowell.

The 1964 work in the Hollis and Twelvemile areas is not included here. Since that work disclosed a ther large number of anomalies. additional work and geological mapping was done in 1965. The work for both years in these areas will be reported in a forthcoming geologic report.

\section{Sampilirg and Analyses}

Stream sedimerit samples were collected from qravel or silt under running water at points in streams above tidal. influence. The character of the stream (swift or sluggish), the width, gradient, type of bedrock, if exposed, and prinoipal constituents of the gravel were noted at each sample site. Also. the stream sediments were tested at the sample site for cold extractable total heavy metals by the use of dithizone salt, and unleaded gäsoline. Toluene was used as a substitute for lndagded gasoline but results did not differ significantly.

Samples were dried, screened through 80 mesh, and sent to a laboratory for analysis. Erequent checks confirmed tho accuracy of laboratory reports within acceptable limits. Most of the analytical work was performed by the Rocky Mountain Ceochemical Laboratory. Considerable assistance was given by the U.S. Bureau of Mines at Juneau, which also did some petrographic and spectregraphic work. In 1964, the U.S. Geological. Survey gave valuable assistane in the fleld of geochemistry. some assaying but no geochemical work was done by the Division of Mines and Minerals laboratory in 1965.

Generally, the field tests and laboratory tests do not check satisfactorily. However, it does appeax that field testing in a stream with markedly anomalous quantities of metal, especially coppers, can be a valuable, rapia guide. 
There is no set rule for determining that quantity of metal in stream sediments that marks the upper limit of normal distribution beyond which all quantities may be considered anomalous. A metal source, such as a near-surface ore body feeds metallic ions into surface waters collected by streams, and the ions are, to a varying degree, adsorbed by particles of clay in the stream sediments. Some clayg have higher adsorbent qualities than others: other lons or solids may cause precipitation, or, conversely, prevent precipitation. Little is known of the effect on stream sediments of diluting high metal content waters with barren waters.

Consequently, the "anomalous" values used in this report may be questioned. A moderately high but legg-than-anomalous quantity of metal in a large stream or in a group of adjacent streams may be more significant than a supposediy anomalous value in a single, smaller stream.

On the following pages the distribution of copper, lead, zinc and molybdenum in stream sediments from those portions of southeastern Alaska sampled to date is shown. The vertical scale shows the percentage of all samples that have the quantity of metal shown on the horizontal scale. In order to more accurately portray the actual distribution of metal the curves are smoothed by calculating a moving average of three quantities.

Even the moving average does not smooth the curve for the distribution of zinc, and the Hollis area, which is abnormally high in zinc, is omitted. Obviously. some types of sediments (the more carbonaceous shales and their equivalents)normally carry more zinc than other sediments.

Thie metal content beyond which the distribution of a metal becomes erratic is taken as the anomalous value. For example, the distribution of copper decreases gradually to about 150 parts per million and then becomes erratic at the higher values.

Although the great majority of samples showed less than 30 parts per million of lead thexe is a gradual, rather than an erratic, reduction in the number of samples with values in excess of 30 parts per million. However, 60 parts per million, rather than 80 , is taken as the threshold of anomalous values for lead because the downstream distribution of lead decays more rapidly than for copper or zinc, and lead values in the range of 60 ppm are likely to be significant.

Insufficient samples were run for nickel to permit a graphic determination of an anomalous value. For the purpose of this report, the anomalous value of nickel is taken to be $150 \mathrm{ppm}$. 
Therefore, in thia report, metal contents of stream sediments in excess of the following are considered to be anomalous:

$\begin{array}{lr}\text { Copper } & 250 \mathrm{ppm} \\ \text { Lead } & 60 \mathrm{ppm} \\ \text { Zinc } & 300 \mathrm{ppm} \\ \text { Molybdenum } & 14 \mathrm{ppm} \\ \text { Ni.ckel } & 150 \mathrm{ppm}\end{array}$

F.C.L.LNO

Prospecting Suggestions

Skagway: possible molybdenum orebody in a sheared portion of coarsely oxytalline quartzofeldspar rocks within a complex granitic batholitho

Wililam Hensy Bay. Iynn Canal: lead-zinc, silver(3) in a zone of strong cross-folding and faulting of Paleozolc limestones, phyllites, ara volcanics.

Mgnsfidd feningula, Admiralty lsland: leadwine-gilver, nickel, possibly gold (Hawk Inlet). The anomalies are closely south of an idle golo mine and five miles wouth of a known nickel orebody. Foeks axe schists with flows, dikes, silis and plpes of basic, ty incermediate igneous compostion.

Gambler Bay. Aamiraity Islands two locations with possible lead-zinc. silver (z) in Txiassic limestones and chert-molomite breacias one posalbie molybdenum deposit in figsile, mireaceus achists.

Pybus Bay, Admiralty rsland: copperwine in wabonaceous, thirmbeddat chert axd argilitite (Devoniani.

Holis. Prinse of wales l'sland: copper-zinc and leadkinc anomalies in this formet gold mining area will be covered $i x$ s siepate geologic report.

Anomalous values have been found in places other than those meritionsd above but the authors believe that first priority in prospecting should be given to tho areas listed.

None of the areas suggestea for prospecting has been sufficientily deingated by geochemical prospecting to warrant tresching or dxilling or even gli save geophysical methods. consequently, the axeas with known anomalies should be delineated by additional geochemical testing of stream seliments, rock chip samples, and soits. 
Testing of samples at the sampling oite is by far the most rapid method of tracing an anomaly to its source, but the cold extraction methods employed in on-site testing are not sufficiently reliable to permit complete, reliance on this method. Furthermore, there is no known cold extraction method that will indicate molybdenum. It is suggested that a cold extraction method be used, but that samples also be sent to a laboratory for analysis.

In many of the swiftly-flowing streams in Southeastern Alaska, it is difficult to obtain suitable stream sediment samples. In order to get rellable regults, it is often necessary to search for small sand pockets near boulders or logs. For uniformity, ali samples should be taken under running water. Very sluggish streans and ponds often give a high reaction in the cold extraction tests becauge of the presence of hưric acid from decaying vegetation.

If a drainage survey outlines an area of interest, further delineation of the possible metal occurrence should be done by soil sampling. On most of the hillsides in Southeastern Alaska there is a thin mantle of soil underneath a mat of decayed vegetation, or clay may be found in hillside rubble. The vegetation should be avoided as much as possible.

For those who are not familiar with geochemical prospecting methods, the following books are recommended:

Geochemistry in Mineral Exploration by H.E. Hawkes and J.s. Webb, Harper \& Row, Publishers. Inc., 49 East 33rd : Street, New York 16. New York. Price $\$ 12.50$.

U.s. Geological Survey Bulletin 1152, Analytical Methods Used in Geophysical Exploration by the U.S. Geological Survey. Superintendent of Documents, Washington 25, D.C.

Bulletin No. 3. Geochemical Prospecting, University of Alaska, School of Mines, College, Alaska, 99735.

Handbook for the Alaskan Prospector by Exnest Wolff, Mining Research, University of Alaska, College, Alaska. Price $\$ 5.00$ at most bookstores.

A fleld kit for cold extraction testing can be assembled from information in U.S. Geological Survey Bulletin 1152, or, more simply, from Bulletin No. 3 of the school of Mines of the University of Alaska. Complete field kits may be purchased from Exploration Laboxatories, Inc.. Box 396, Sausalito, California, 94965. The cost of these kits ranges from $\$ 16.75$ to $\$ 58.00$. 
Reliable laboratory analyseg may be obtained from the laboratorieg listed below. These laboratories charge for sample preparation (usually $\$ 0.50$ a sample) if screening is not done before hand. Analytical charges are based on reasonably large lots; for only a few samples the charges may be higher than shown.

$$
\begin{aligned}
& \text { Rocky Mountain Geochemical Laboratories, Box } 2217 \text {, } \\
& \text { Salt Lake City, Utah, } 84110 \text {. Charges are } \$ 1.00 \text { for a } \\
& \text { gingle metal in a sample; } \$ 1.50 \text { for two metals in the } \\
& \text { same sample; } \$ 1.80 \text { for three metals; } \$ 2.00 \text { for four } \\
& \text { metals. } \\
& \text { Exploration Laboratories. Inc.. Box } 396 \text {, Sausalito, } \\
& \text { cadifornia, } 94965 \text {. Charges are } \$ 0.80 \text { for one metal in } \\
& \text { a rample and } \$ 0.40 \text { for each additional metal. }
\end{aligned}
$$

Aerial photographs, which are aimost a necessity for a prospector, are available for all southeastern Alaska.

For most purposes, an area may be marked on a U.S. Geological Survey map and sent to the survey with the request that photo coverage be provided. However, it is better to have an index map of the photographs avallable. These indexes may be purchased from the survey and be used to pick out by number the exact photograph or photographs required. The small index map is difficult to read, so it is advisable to get the enlargement. Orders should be sent to:

$$
\begin{aligned}
& \text { J.O. Kilmartin, Chief } \\
& \text { Map Information Service } \\
& \text { U.S. Geological Survey } \\
& \text { Washington, D.C. } 20242
\end{aligned}
$$

Each small index map, which is a reduction from a standard oneinch-to-four miles quadrangle map. costs $\$ 1.30$; an enlargement costs $\$ 2.20$. Individual 9" 9 9" photographs cost $\$ 0.85$ each.

The U.S. Forest Service expects to have available at Juneau complete indexes and flles of negatives of aerial photography covering all of Southeastern Alaska. Prints will probably be made for the public, but the charge has not been established. The Forest service photos show considerably more detail than do those presently available from the U.S. Geological survey. 


\section{ABBREVIATIONS}

In the sections on the individual areas which follow, the tables show the map number, which refers to the location of a sample site on the map of the area. The sample number is the field number given to the sample when taken.

Metal content is expressed in parts per million as determined by laboratory analyses.

The number of milliliters of dithizone solution used in the field test required to remove a color caused by heavy metals in one-half gram of sample is abbreviated as $\mathrm{ml}$ dyo $\mathrm{Cx}$.

Other abbreviations:

Elements:

$\begin{array}{ll}\mathrm{Cu} & \text { copper } \\ \mathrm{Pb} & \text { lead } \\ \mathrm{Zn} & \text { zinc } \\ \mathrm{Mo} & \text { molybdenum } \\ \mathrm{Ni} & \text { nickel } \\ \mathrm{Au} & \text { gold } \\ \mathrm{Ag} & \text { silver }\end{array}$

Colors:

$\begin{array}{ll}\text { cls } & \text { colorless } \\ \text { or } & \text { orange } \\ \text { vio } & \text { violet } \\ \text { lav } & \text { lavender } \\ \text { brn } & \text { brown } \\ \text { blk } & \text { black } \\ \text { grn } & \text { green } \\ \text { lite } & \text { light in color } \\ \text { int } & \text { intermediate in color } \\ \text { dark dark in color }\end{array}$

Miecellaneous:

$\begin{array}{ll}\text { inter } & \text { interphase } \\ \text { ppt } & \text { precipitate } \\ \text { Tr } & \text { trace }\end{array}$

\section{Rocks:}

\begin{tabular}{ll} 
ap & aplite \\
d & diorite \\
$g$ & granite \\
gd & granodiorite \\
mz & monzonite \\
gb & gabbro \\
Is & limestone \\
do & dolomite \\
ar & argillite \\
sh & shale \\
bs & black shale \\
gc & schist \\
gy & graywacke \\
ph & phylitte \\
cg & conglomerate \\
grg & greengtone \\
br & breccia \\
ch & chert \\
an & andesite \\
vol & volcanic rocks (unclassified) \\
metased & metasedimentary rocks \\
gn & gneiss \\
m & marble \\
intr & intrusive \\
qtz & quartz \\
silic & gilicified \\
cal & calcareous \\
sed & sedimentary rocks (un- classified) \\
& \\
- & \\
\hline
\end{tabular}




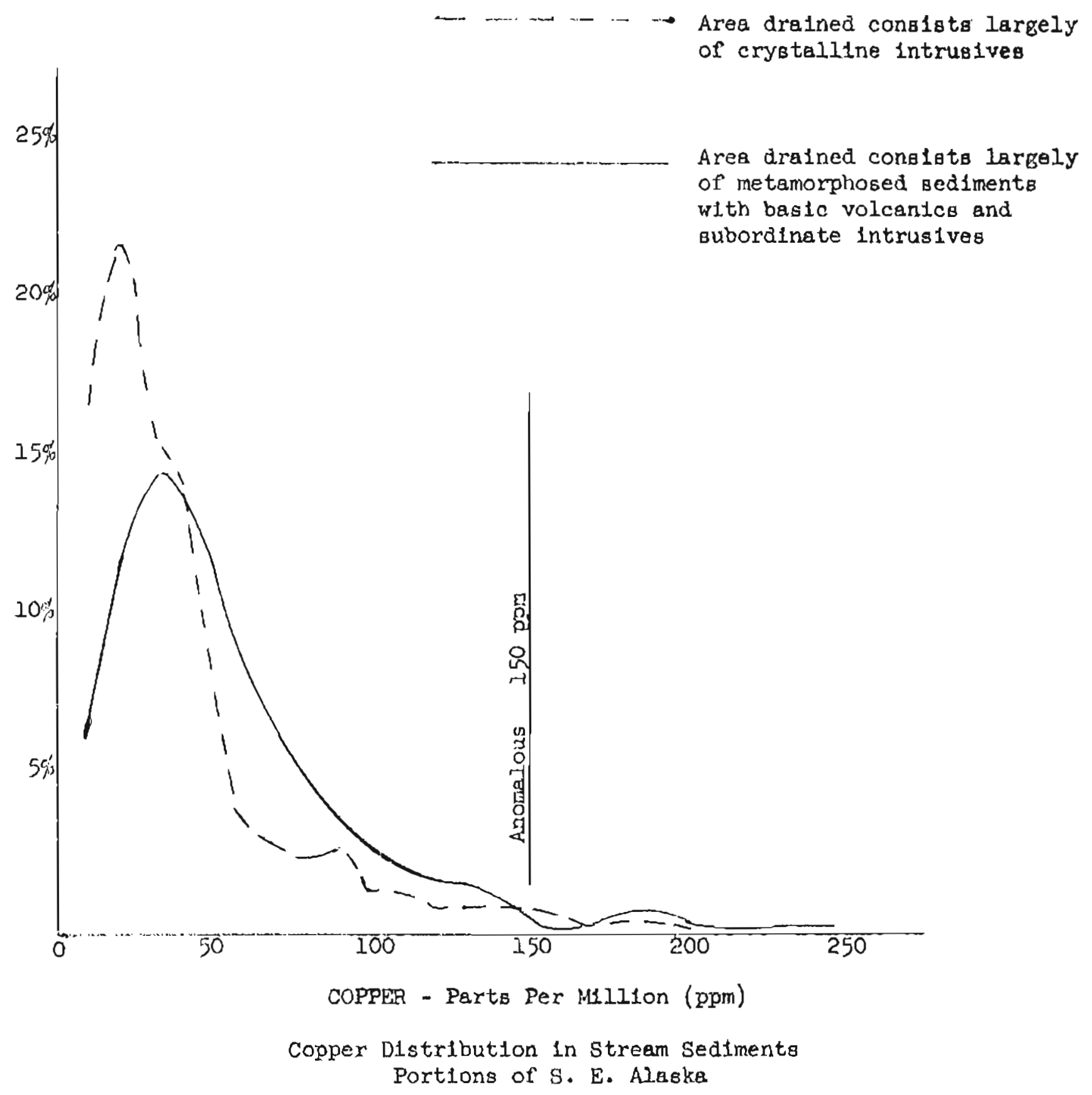




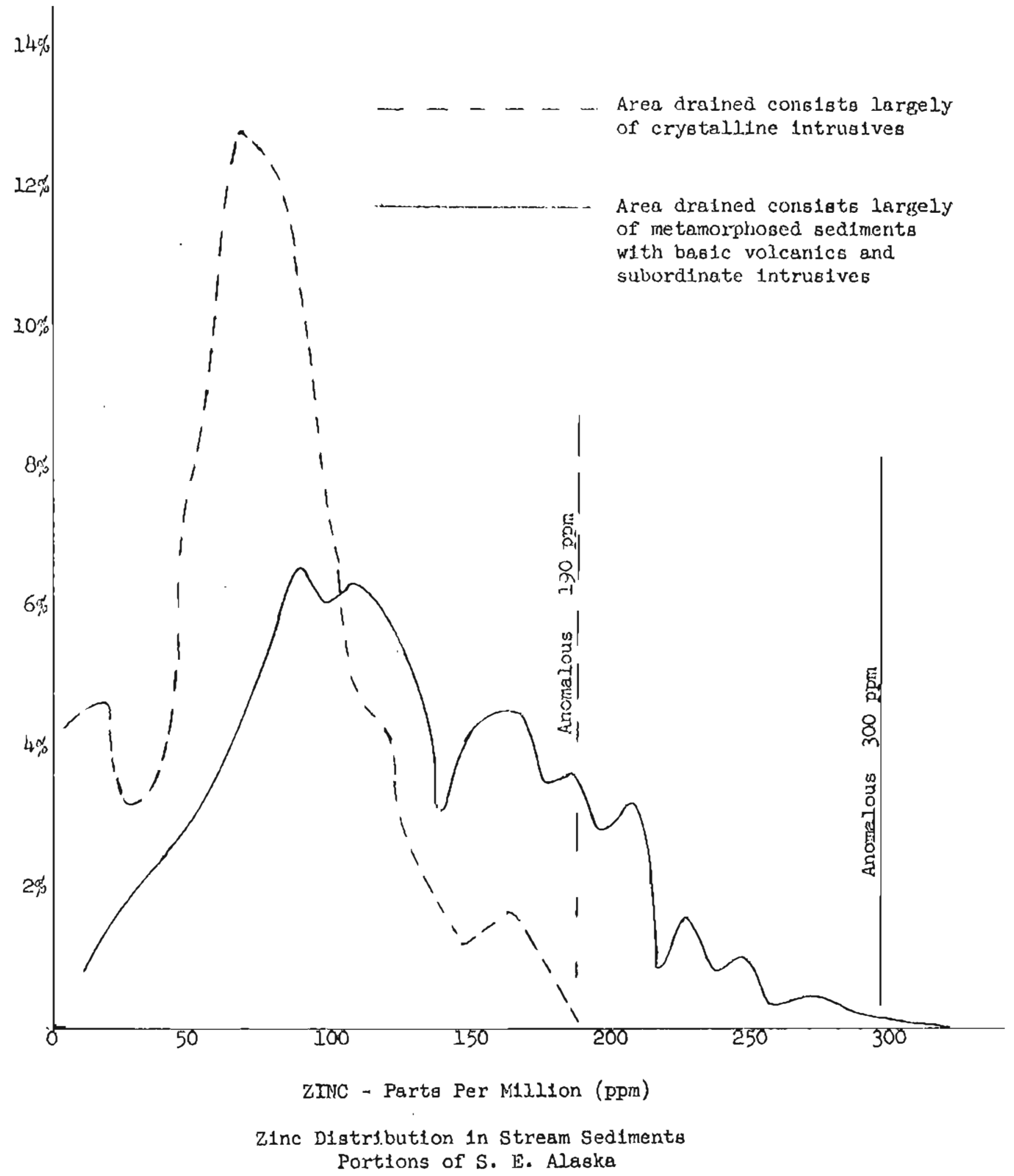

Note: Hollis area which has median value of 190 is excluded 


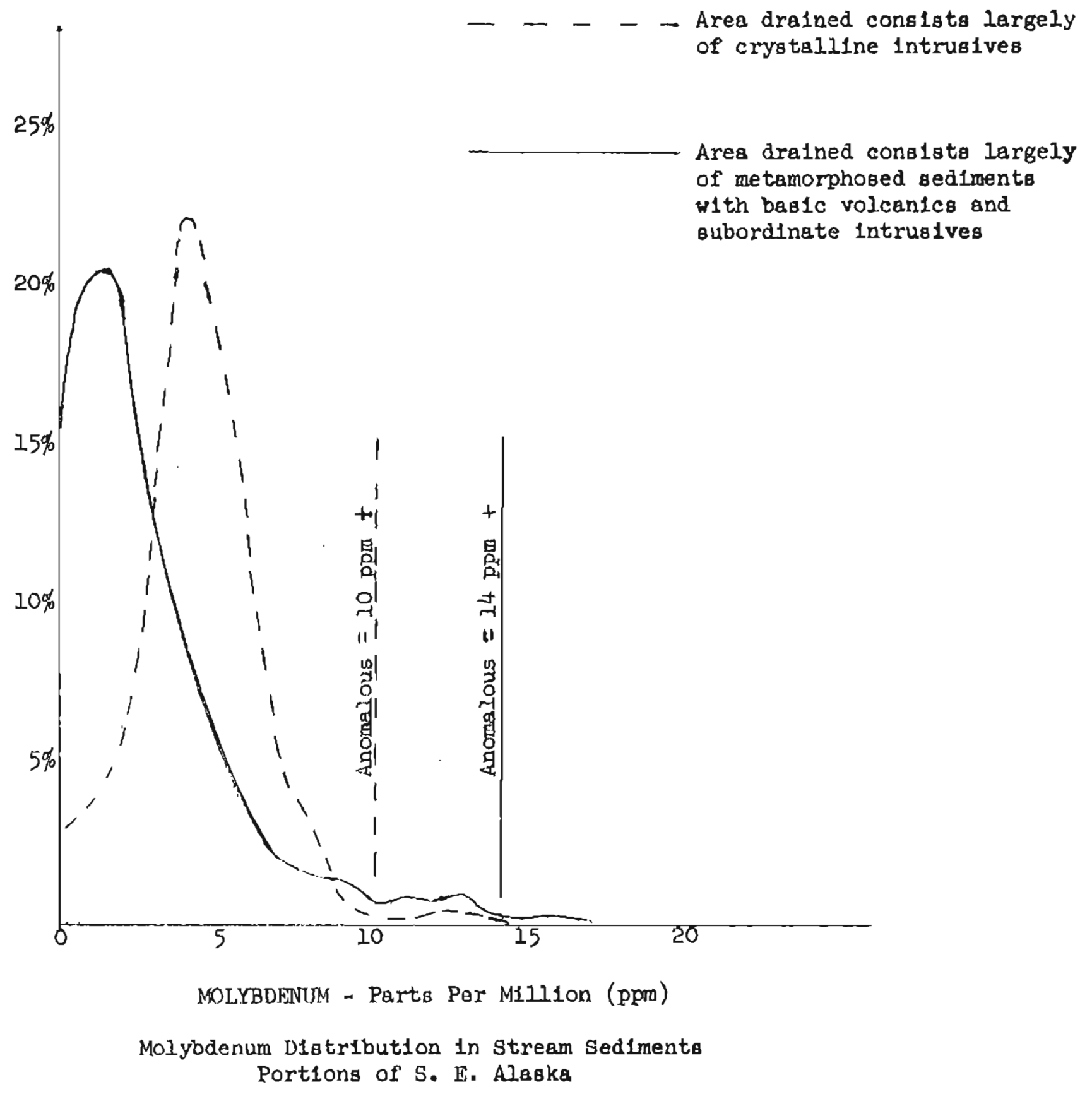




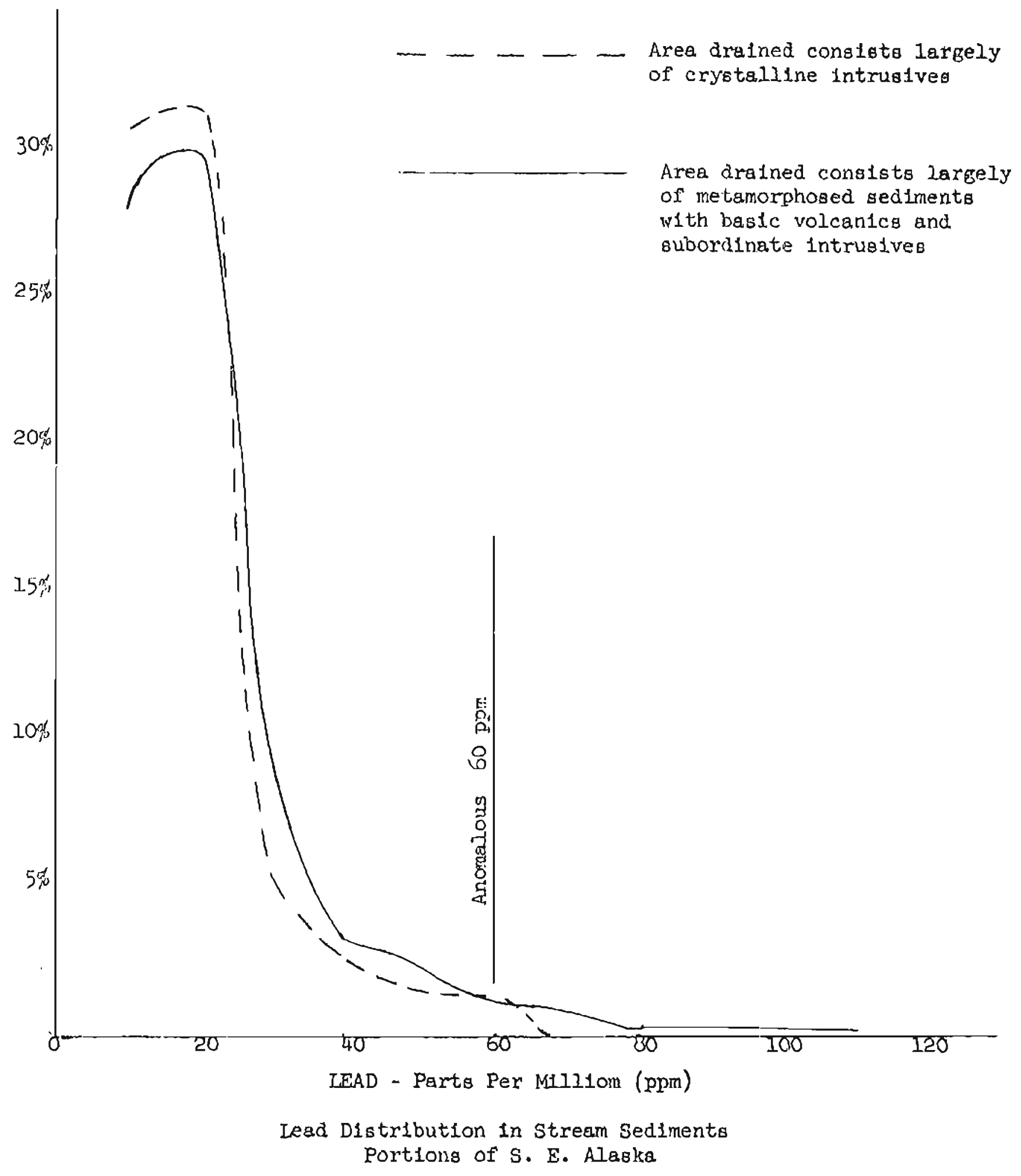




\section{SWAGWAY}

Ska.gway is located at the north end of Lynn Canal approximately 90 miles north of Juneau. It is the southern terminus of the White Pass and Yukon Railroad, which runs north to Whitehorse, Yukon Territory, Canada.

Mineral production from the immediate vicinity of skagway has been very limited. The Inspiration Mine produced a Eew tons of ore which had values in silver, lead, zinc, and copper. Some prospecting was done on a molybdenum occurrence near clifton, a station on the railroad about eight miles north of Skagway, and molybdenum has been found at other places near the railroad.

\section{Geology}

Skagway is located in an area of granitic rocks that form the Coast Range batholith. Metamorphosed sediments occur within the granitic rocks just west of town. The wegtern limit of the batholith appearg to lie between Skagway and Haines and its eastern edge is apparently near the Alaska-Canada border. Reconnaissance geology of the area is described in U.S. Geological Survey Bulletins 926-C, "Occurrences of Molybdenum Minerals in Alaska"anc 800, "Geology and Mineral Deposits of Southeastern Alaska "

A copy of a thesis by Fred Barker, "Coast Range Batholith Between Haines and Lake Bennett, B.C.." was made available by Mr. Emil Maki of skagway. The bedrock classifications shown on the attached map of the area are those of $M x$. Barker.

\section{Previous Work}

Many years ago a shallow shaft was sunk on a molybdenite-bearing aplite dike northeast of clifton and a short tunnel was driven on a molybdenite discovery west of map location 2 and below the railroad grade. There have been superficial searches for molybdenum on the steep. well-exposed slopes in the vicinity of clifton, but there is no evidence of other underground work nor of surface trenching in the covered areag, although scattered grains of molybdenite may be found over a large area.

Over ten years ago a zone of high radioactivity close to skagway caused considerable excitement, and there have been several discoveries of short, thin lenses of argentiferous galena in the tight batholithic rocks. 
The skagway area is much arier than the rest of Southeastern Alaska and the batholithic rocks have few watercourses. Consequently, there wexe few streams available for stream sampling.

Map locations 1 to 5 indicate a molybdenum anomaly associated with a north $60^{\circ}$ east fracture zone that prolsably continues southwesterly chrough map locations 9 to 13 .

In the Taiya River valley at map locations 15 to 17 , a strearn is Elowing from a spring in glacial gravels and is depositing a large amount of iron oxide. Although stream sediment samples were not anomalous, the water tests show very high values with a thick reci precipitate that is considered to indicate the presence of consicierable lead. A similar cre reaction with stream sediments was noted at map location 18 on the West Branch, but, at map location 19, also on the West Branch, no anomaly was apparent, zircon was found in the gravel at map locations 18 to 22.

\section{Prospecting}

In view of the high molybdenum content of stream sediments from streams that drain the covered shear zone extending from the hill above clifton down into the skagway River, it would appear that an area about one mile long and five hundred feet wide should be prospected by soil sampling, followed by trenching of any anomalous areas indicated by such work. There is room in this shattered zone, indicated by high water content and vegetation, for a molybdenite ore body, most likely in or along the sontact of the coarser grained quartz-feldspar rocks. 


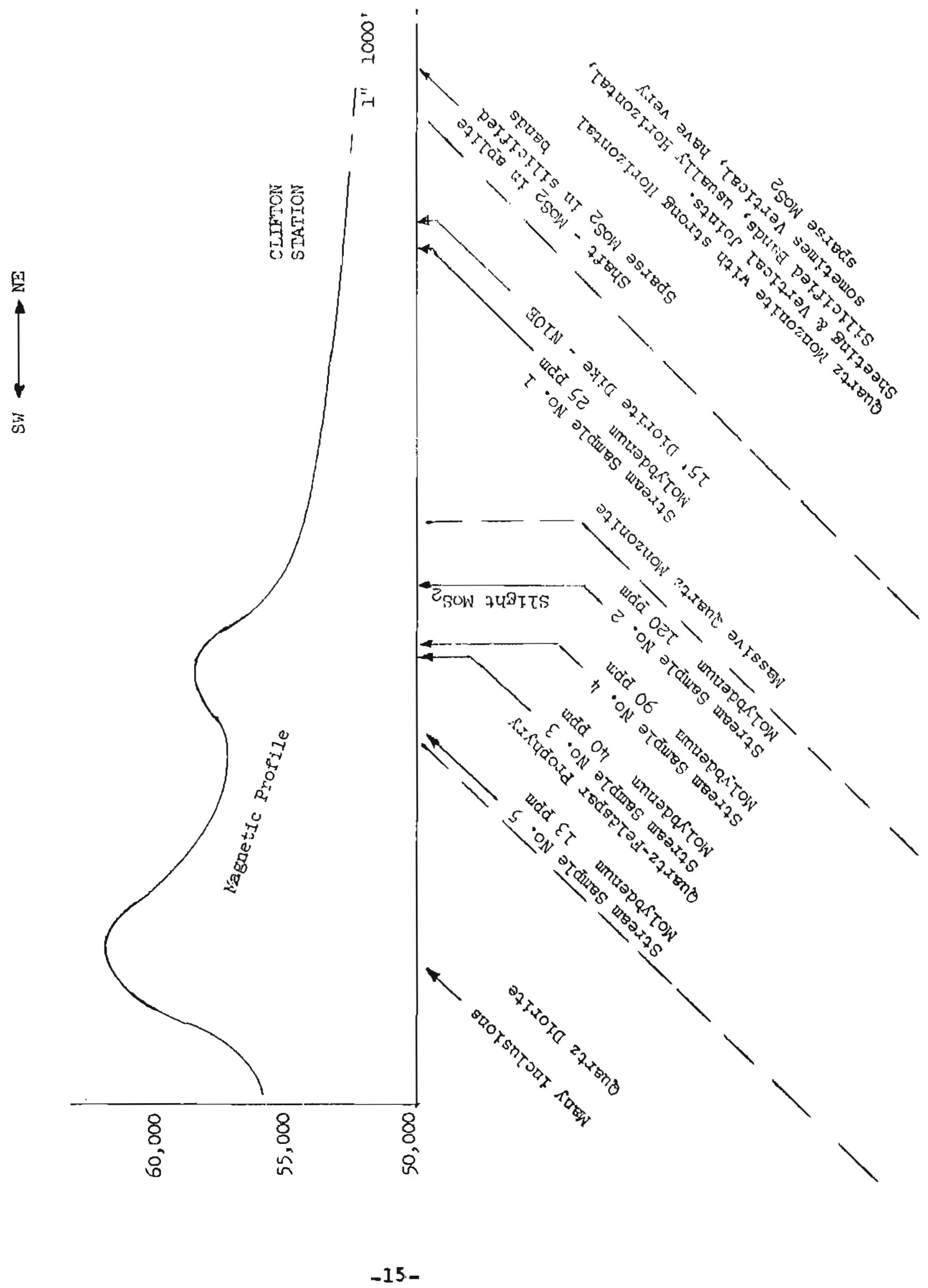




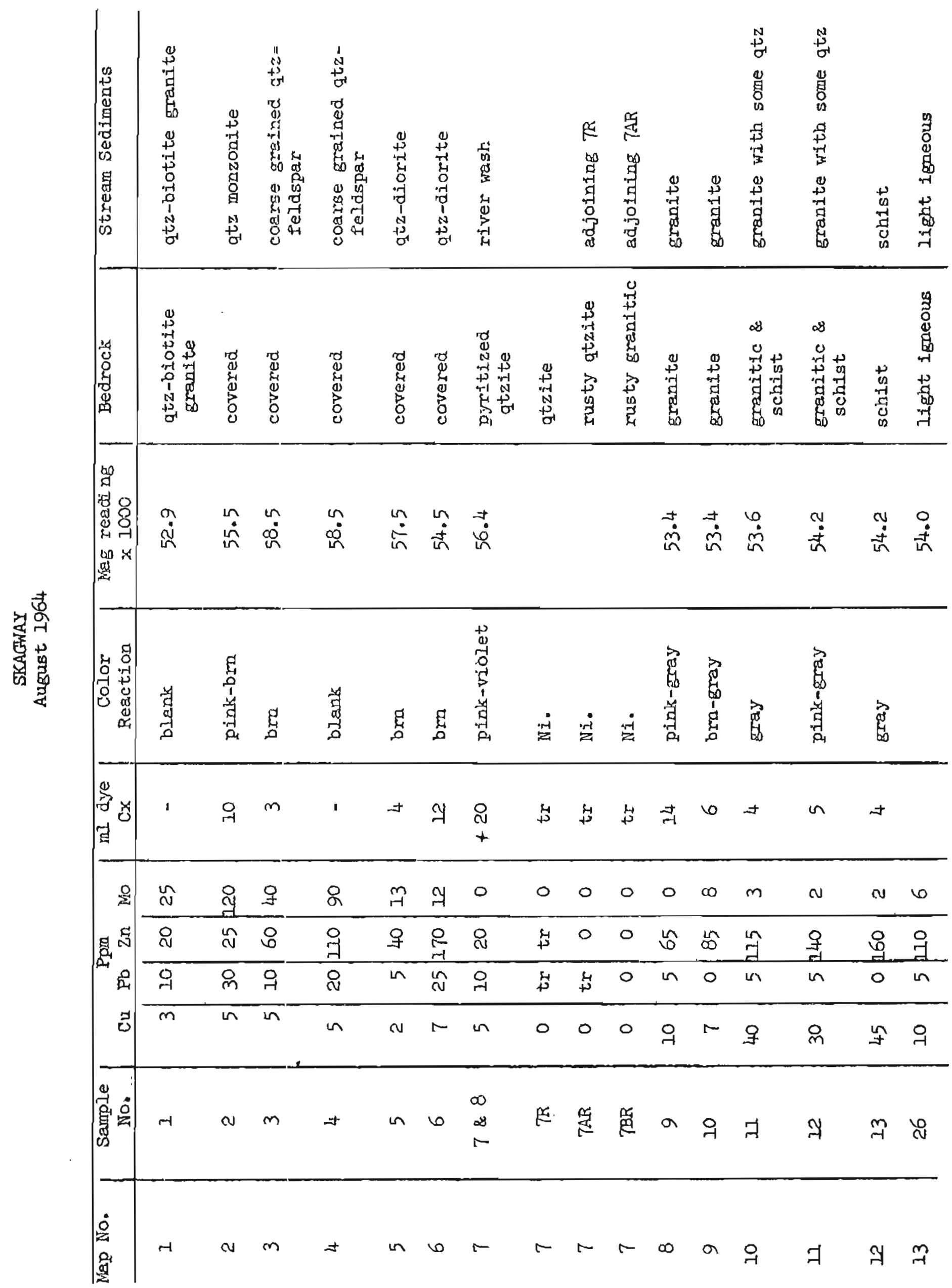




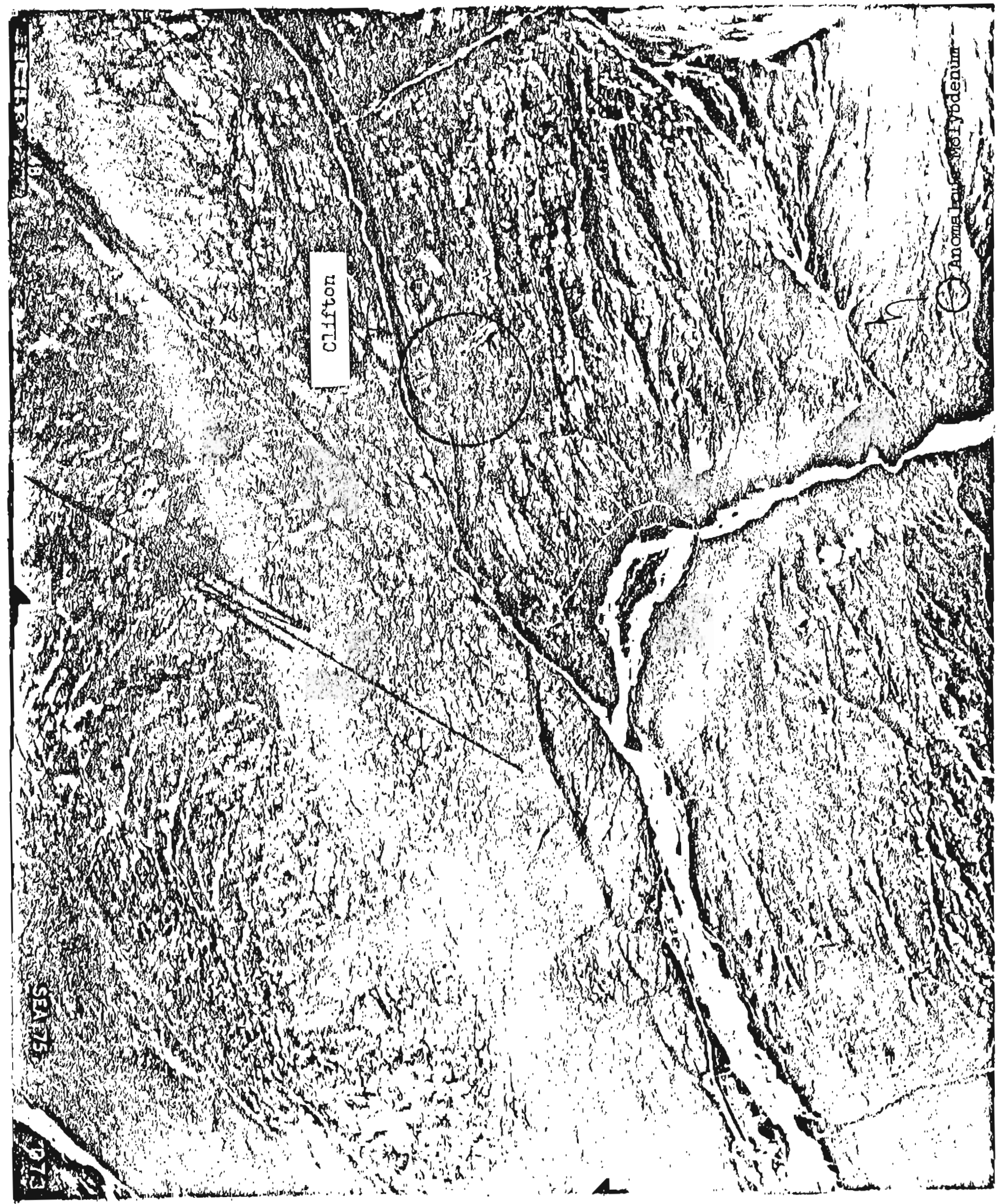




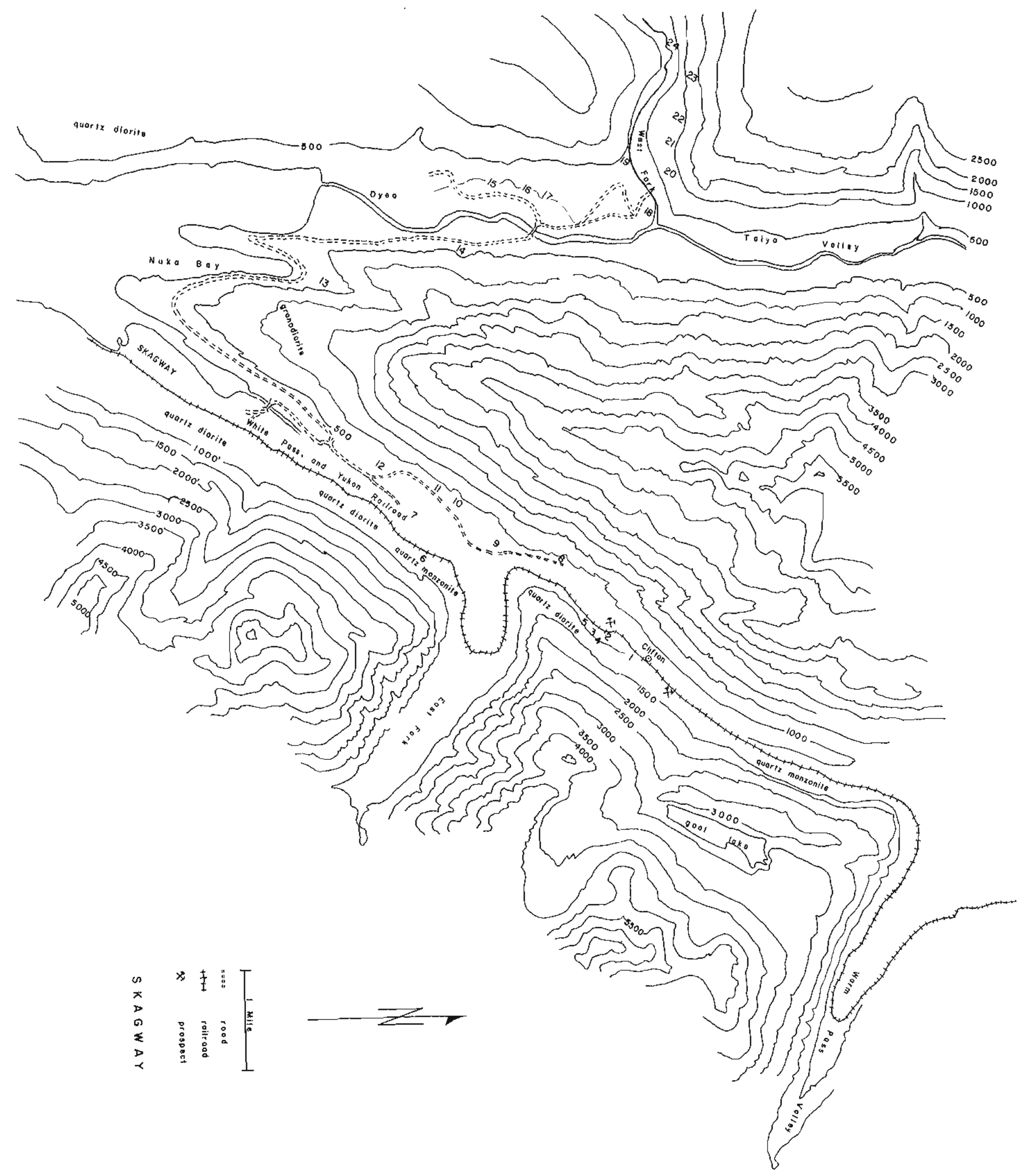


Glacier Point, located on the west side of Lynn Canal about gixty mileg north of Juneau and fifteen miles south of Haines, is a delta built up by the outwagh from Davidson Glacier, which, like other glaciers in the area, is nuw receding and providing new rock exposures along the valley walls. There are no old prospects or mines in the area other than a recent copper-iron discovery by Mr. Howard Hayes, a local logging operator. and a copper prospect located north of the Hayes prospect several years ago.

The Hayes discovery was made by Dale Henkj.ns, a geology student in Mr. Hayes' employ.

\section{Geology}

The geology of the area has not been mapped but during tine investigation it was noted that the general geology and structure whown on the north end of USGS Map I-303 continues through Glacier Point. The rocks are metasediments, including harlibized limestone and gneiss, with a northwesterly strike and some easc-west faultirig. The south end of the Chilkat Peninsula (opposite Glacier Point) is tuff and lava. The mainland and the Chilkat Peninsula are separated by the major fault zone that extends for $250 \mathrm{miles}$ or more down Iynn Canal and Chatham strait.

\section{Geochemical Investigation}

Twenty stream sediment samples were taken, including samples taken in the vicinity of the Howard Hayes prospect.

The variation between the cx tests and the laboratory tests is remarkable. Note that the high Cx tests in no case were confirmed by laboratory work and that high laboratory result:s were not compatible with Cx testing. The discrepancy was especially notable at map locations 18 and 19 where the Cx tests gave a strong color that persisted at the end of the testing range; nevertheless, laboratory results were not anomalous.

\section{Howarả Hayes Prospect}

This newly discovered prospect is located on a steep cliff at the head of a talus slope that contains float of magnetite in marble, and chalcopyrite with hematite, in an impure, schistose limestone partially altered to skarn. The magnetite outcrop was examined in some detail but the schistose limestone was largely inaccessible.

The deposit is interpreted as consiating of low grade mineralization in metamorphic rocks close to east-west faulting, which has formed slices of varying composition. 


\section{Prospecting}

The higher copper content at map locations 11 to 13 may be derived from a northwesterly zone of structural weakness that is more or less in line with the Hayes prospect and the older prospect to the north of it. since the creeks cut this zone on a steep mountain side it should be possible to locate the metal source by geochemical sampling of the streams and a search for float in the stream wash. 


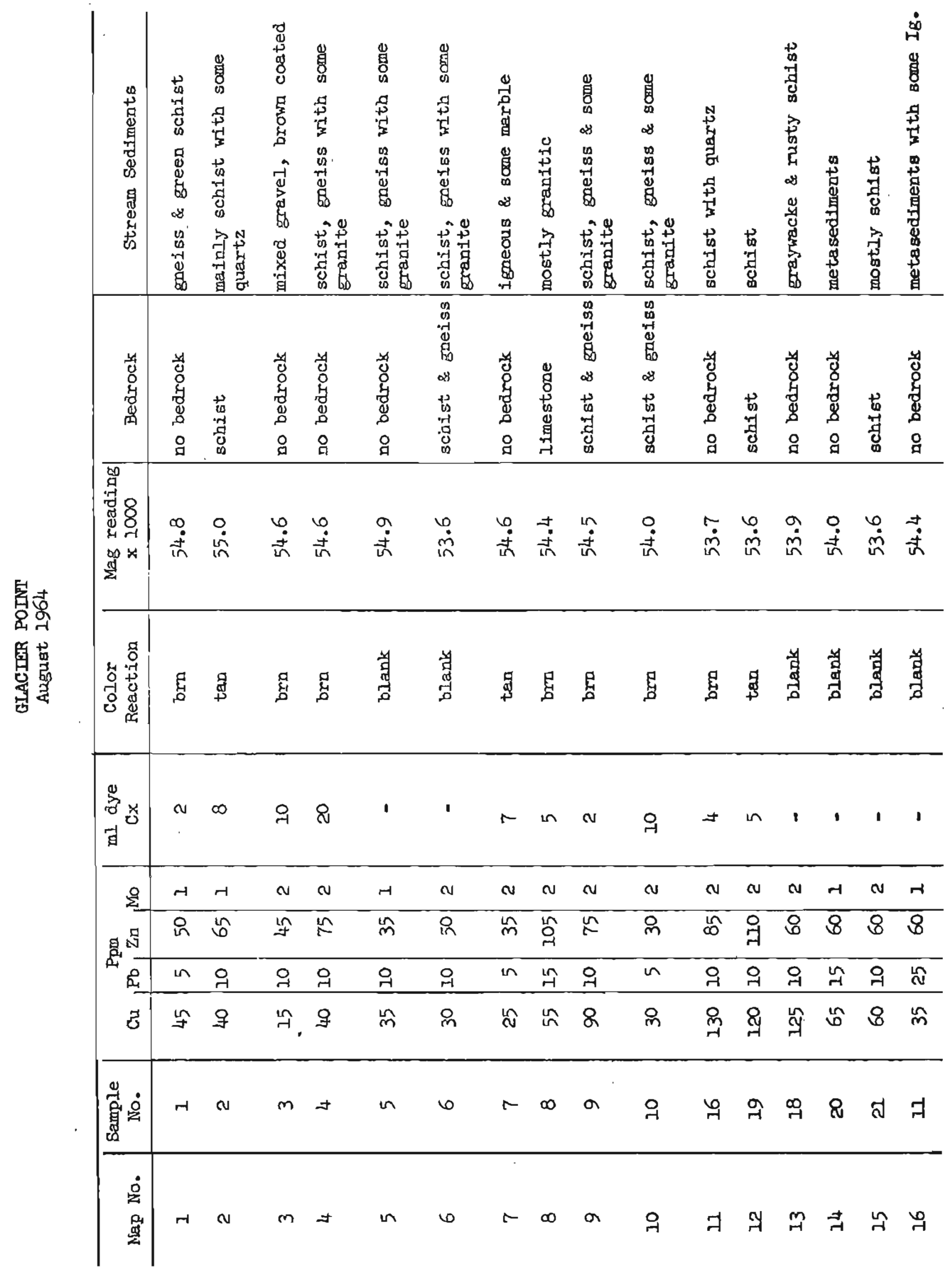



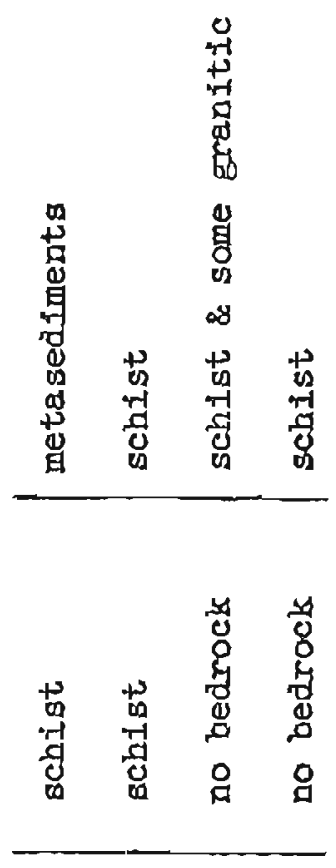

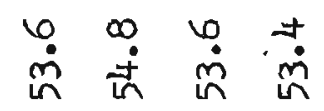

$\begin{array}{llll}+ & w & + & + \\ 0 & 0 & 0 & 0 \\ 0 & 0 & 0 & 0 \\ 0 & 0 & 0 & 5\end{array}$

n $8 \mathbb{x}_{+}$ल

$\begin{array}{lll}8 & n \in d\end{array}$

\begin{tabular}{llll}
\hline$\circ$ & $\circ$ & 8 & $\circ$ \\
\hline n & 9 & $m$ & m
\end{tabular}

吕 $\vec{r}$ त्

닥 ศ 8 


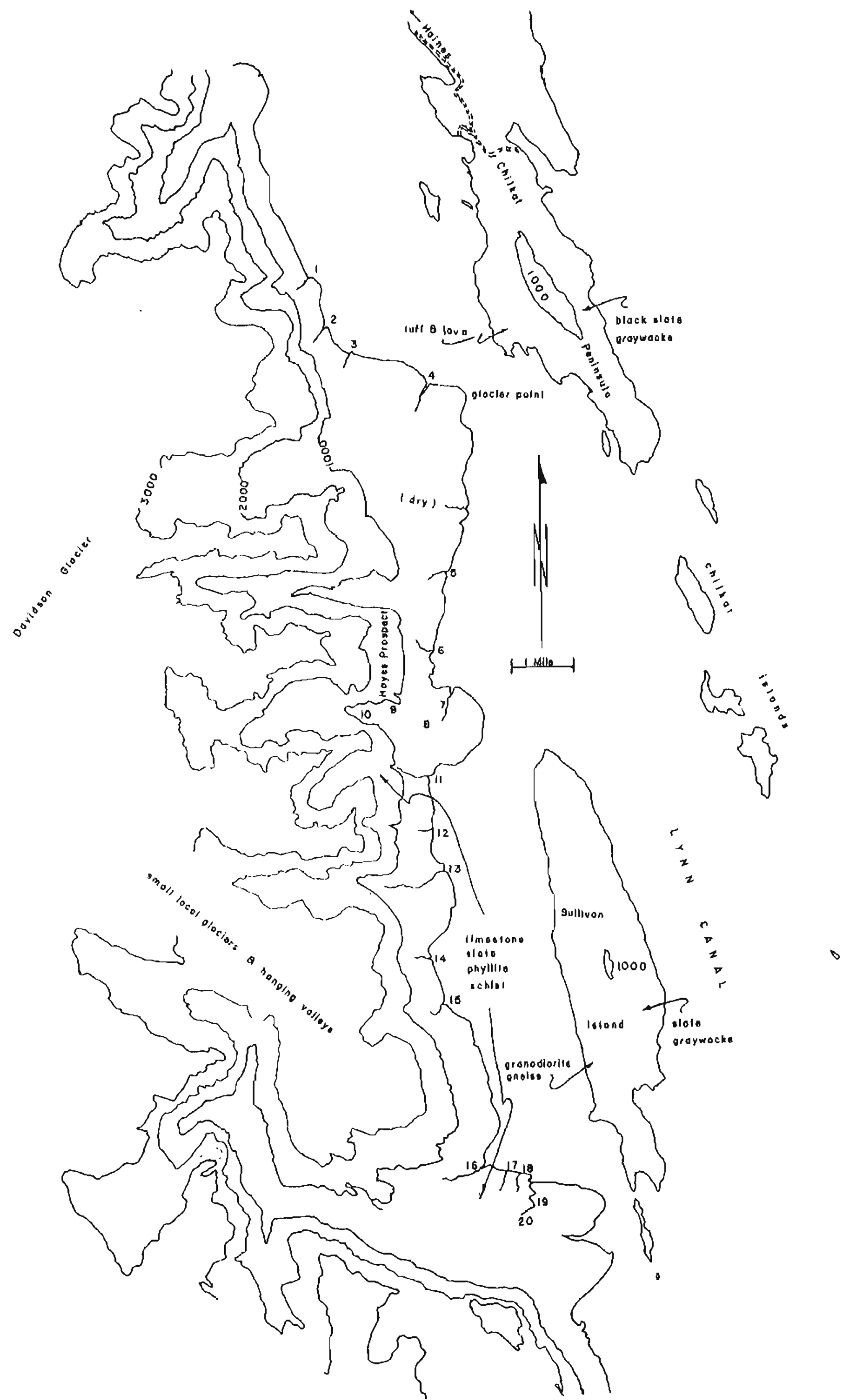




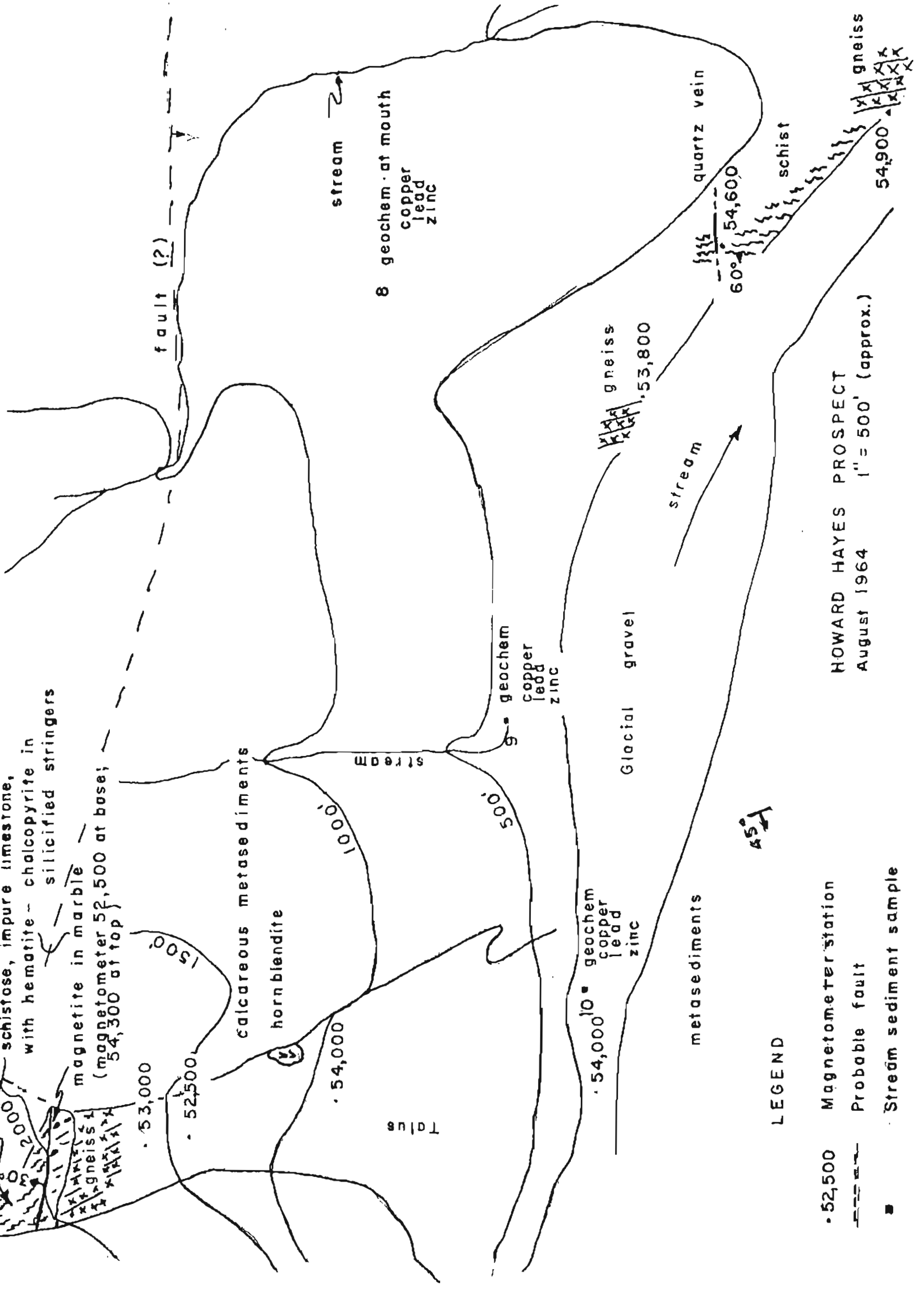


St. Jameg Bay and Willian Henry Bay are on the west side of Lynn Canal thirty to forty miles northwest of Juneau. Prior to 1919 over a thousand feet of drifts and tunnel were driven in a copper mine south of the head of William Henry Bay. Shipments from the mine returred $\$ 1.020$ in gold and silver. but there is no report on the value of the copper recovered.

\section{Geology}

The area considered liea north of a large mass of granodiorite (not shown on the accompanying mapl and consists of silurian and devonian graywacke, argillite and andesitic flows, with some intercalated limestone. These rocks trend northwesterly and dip steeply to the rortheast.

In the vicinity of William Henry Bay a major northwesterly thrust fault is warped sharply to the east by cross-faulting and folding, which involver a bed of Permian limestone. Intrusions of diabase and diortte occur northwest and southwest of the bay.

The geology of the area 1 s described and illustrated in the following publications by the U.S. Geological Survey" Bulletin 714. "Mineral Resources of Alaska, 1919": Bulletin 963-A. "Some Mineral Investigations in Southeastern Alaska": Map I-303, "Progress Map of the ceology of the Juneau Quadrangle".

\section{Geochemical Investigation}

The geochemiral investigation was made in conjunetion with a state land appraibal durjirg inue of 1965. William Henry Bay was more thoroughly investigated this year b cause of an anomalous sample taken in 1964 during a stop forced by bad weather.

A total of 11 bamples are reported of which three are anomalous. The stream found in 1964 to be anomalous, on the south side of William Henry Bay, was sampled at higher elevations and found to cortain very high values of zinc.

\section{Prospecting}

A strong lead-zine ancma?y at map localities 8 to 90 ascompanied by much ixon gtaining of the gravel in the creek along which the armples were taken, suggerts a local source of metal. However. lark of minexalized float in the creek makes it seem Improbable that the small creek actually cuts a mineralized structure.

It Io recommendad that the creek be followed by geculbemidal testing. of the stream sediments (posalbily water gampling will work well at this 
locality). Iron staining itself may be a reliable guide. At a point where the anomaly drops or iron stalning decreases, or beyond the head of the creek if anomalies persist that far, soil sampling should be done. The hill is covered with timber and brush, making outcrops scarce except in the creek beds. Consequently, soil sampling seams to be the easiest guide to possible mineralization. The soil cover is thin, so shallow pits can be used to check the results of soil sampling. 


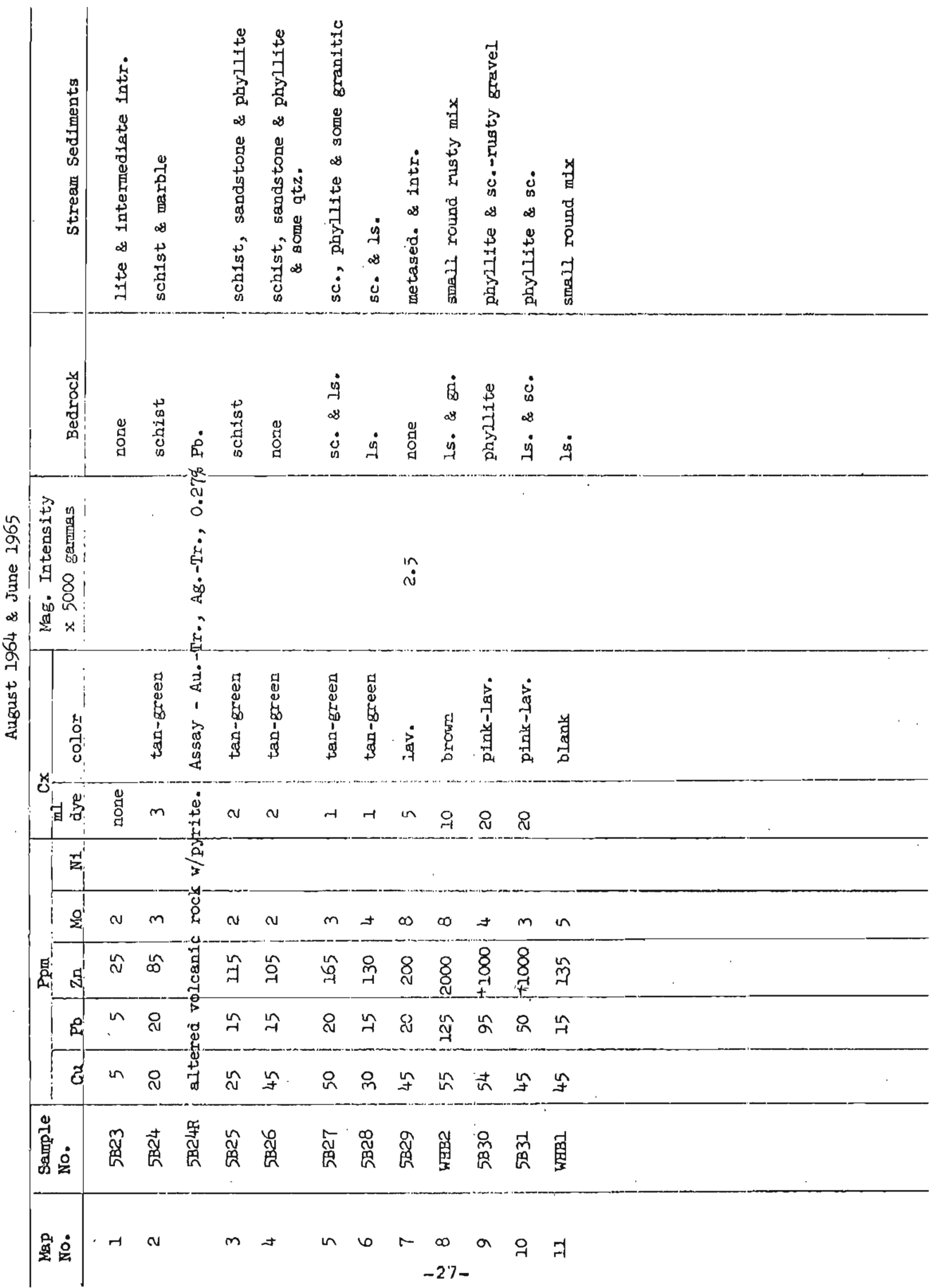




\section{BERNERS BAY}

Berners Bay is situated on the east side of Iynn Canal approximately forty-five miles northwest of Juneau. Gold lode deposits were first disccvered In 1886 or 1887 on Sherman Creek. Between 1890 and 1900. five stamp milis were erected and production exceeded 68,000 ounces of gold before the mines closed a few years later. Copper has been reported in the area, but very little prospeating in recent years has taken place.

\section{Geology}

The geology of Berners Bay is described in the following U.S. Geological Survey Bulletins: Bulletin 446, "The Berners Bay Region, Alaska": Bulletin 800, "Geology and Mineral Deposits of Southeastern Alaska".

These bulleting indicate that the coast range diorite commences at the mouth of the Antlex Rivex, but the eastern limit is not defined. The Canadian Department of Mines and Resources, Geological Survey Memoir 248, Taku River Map-Area, British Columbia, indicatea that bedrock at the border is tuff, graywacke, argililte, conglomerate, breccia, limestone and andesites with minor intrusions. This leads to the corclusion that the Coast Range diorite does not occupy a large paxic of the area so it should be favorable for prospecting.

\section{Geochemical Investigation}

A total of 28 stream sediment samples were taken as well as two rock samples that contalned sulfides. No strong aromalies wexe detected. 
BERNTFR BAY

August 1964

\begin{tabular}{|c|c|c|c|c|c|c|c|c|c|c|}
\hline Map No. & $\begin{array}{c}\text { Sample } \\
\text { No. }\end{array}$ & $\mathrm{Cu}$ & $\mathrm{Pb}$ & Pn & Mo & $\begin{array}{c}\mathrm{dye} \\
\mathrm{Cx}\end{array}$ & $\begin{array}{c}\text { Color } \\
\text { Reaction }\end{array}$ & $\begin{array}{l}\text { Mag reading } \\
\times 1000 \\
\end{array}$ & Bedrock & Stream sediments \\
\hline 1 & 19 & 15 & 5 & 55 & 2 & 8 & violet-brm & 54.0 & graywacke & $\begin{array}{l}\text { black slate \& Ereywacke } \\
\text { strike } 310^{\circ} \text { - dip vert. }\end{array}$ \\
\hline 2 & 20 & 15 & 10 & 60 & 2 & 5 & pink-brn & 54.0 & $\begin{array}{l}\text { Eraywacke } \\
\text { \&.S. }\end{array}$ & black slate \& grayracke \\
\hline 3 & 21 & 25 & 5 & 45 & 2 & - & blank & 54.2 & graywacke & graywacke \& glacial fill \\
\hline 4 & 22 & 20 & 15 & 75 & 2 & 2 & bron & & graywacke & graywacke \& glacial fill \\
\hline 5 & 23 & 10 & 10 & 25 & 2 & 6 & bran & & $\begin{array}{l}\text { argillite } \\
\text { w/pyrite }\end{array}$ & $\begin{array}{l}\text { graywacke \& glacial f1]7 } \\
\text { water test plus } 15 \text { brn } / \\
\text { redcap }\end{array}$ \\
\hline 6 & 24 & 55 & 15 & 135 & 4 & 6 & pink-brn & 54.5 & no bedrock & graywacke \& sone igneous \\
\hline 7 & 25 & 5 & 5 & 10 & 2 & 3 & brn & 53.5 & $\begin{array}{l}\text { Eraywacke } \\
\text { \&. B.S. }\end{array}$ & $\begin{array}{l}\text { graywacke \& sone Brando- } \\
\text { diorite }\end{array}$ \\
\hline 9 & 11 & 45 & 10 & 60 & 3 & 4 & bra & $54 \cdot 5$ & $\begin{array}{l}\text { gneiss \& } \\
\text { argillite }\end{array}$ & $\begin{array}{l}\text { graywacke \& some grando- } \\
\text { diorite }\end{array}$ \\
\hline $9 R$ & 108 & 0 & 0 & 0 & 0 & Assay & geiss with & rite \& chaldc & rite? & \\
\hline 10 & 12 & 10 & 5 & 40 & 2 & +20 & brn & 54.5 & $\begin{array}{l}\text { qtz diorite } \\
\text { gegranodio- } \\
\text { rite }\end{array}$ & mostly granodiorite \\
\hline 11 & 13 & 35 & 15 & 90 & 2 & 6 & brn & 53 & graywacke & milcaseous schist \\
\hline 12 & 14 & 65 & 10 & 85 & 4 & 6 &.$b r n$ & & no bedrock & grajwacke with granodiorite \\
\hline 13 & 18 & 30 & 10 & 75 & 4 & 5 & brn & & $\begin{array}{l}\text { black slate } \\
\mathrm{H} / \text { pyrlte }\end{array}$ & black slate \\
\hline 24 & 17 & 65 & 15 & 245 & 8 & 4 & Violet-gray & 54.5 & black slate & black slate $\mathrm{w} / \mathrm{qtz}$ \\
\hline
\end{tabular}




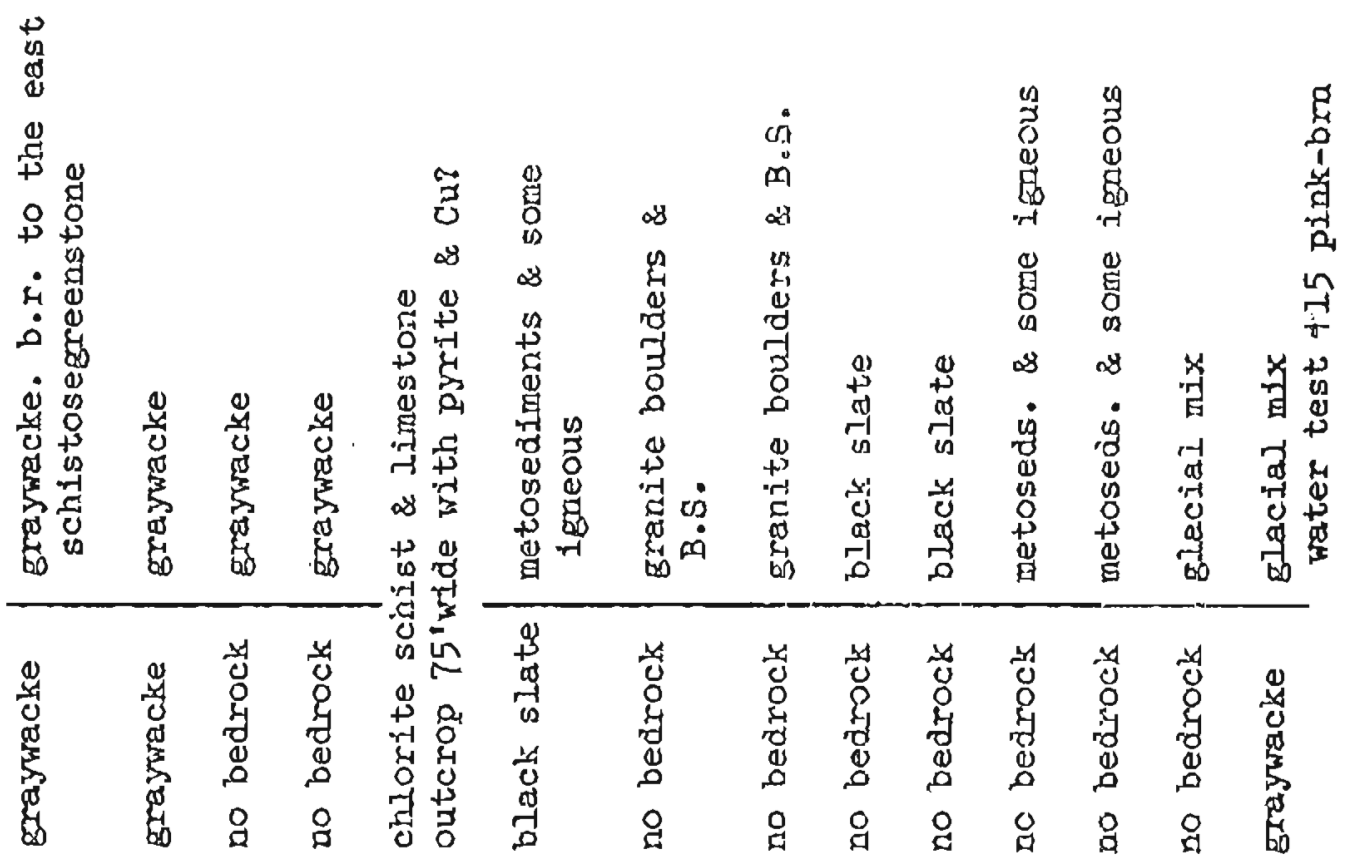

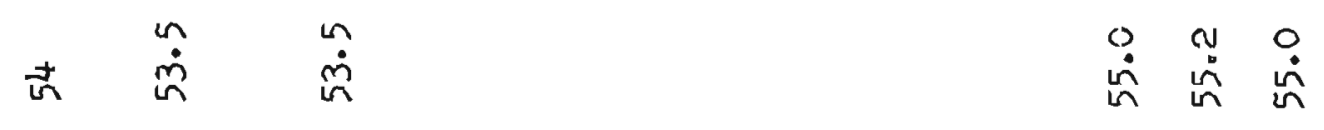

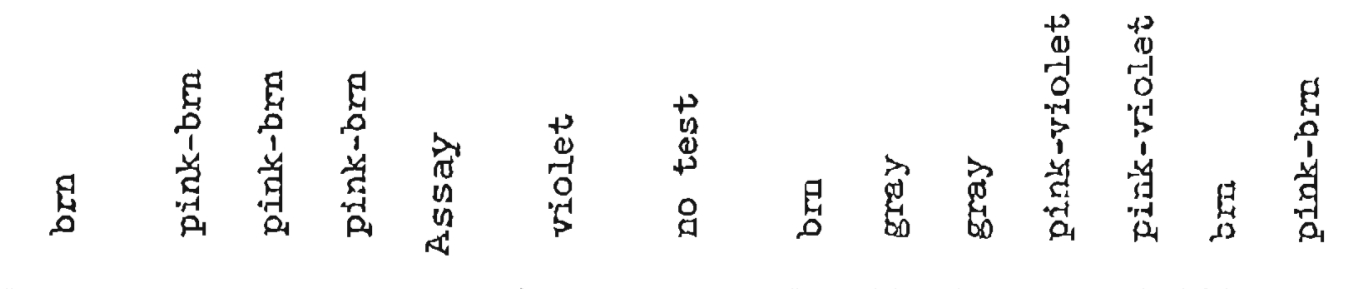

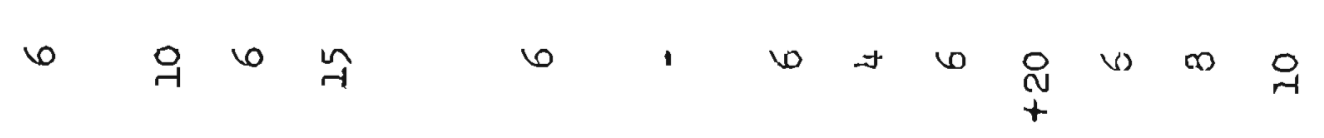

\begin{tabular}{|c|c|c|c|c|c|c|c|c|c|c|c|c|c|}
\hline$N$ & $m$ & $m$ & $N$ & 0 & os & $m$ & $m$ & $m$ & $m$ & $m$ & $\mathrm{~N}$ & $\Rightarrow$ & $m$ \\
\hline$m$ & $\begin{array}{l}0 \\
-1 \\
-7\end{array}$ & In & $m$ & 0 & $\stackrel{n}{n}$ & $\stackrel{\infty}{\infty}$ & n & 8 & 只 & 6 & $\stackrel{9}{=}$ & Nu. & 胥 \\
\hline in & 어 & $n$ & - & 0 & in & in & in & 욤 & n & in & 0 & In & in \\
\hline$\tilde{H}$ & 尺 & m & $\stackrel{\bigcirc}{O}$ & 0 & in & in & $\stackrel{0}{1}$ & in & $\stackrel{n}{c}$ & $\stackrel{9}{m}$ & m & $\stackrel{u}{a}$ & on \\
\hline
\end{tabular}

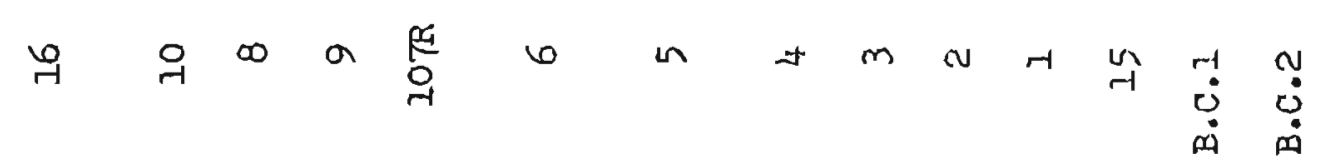

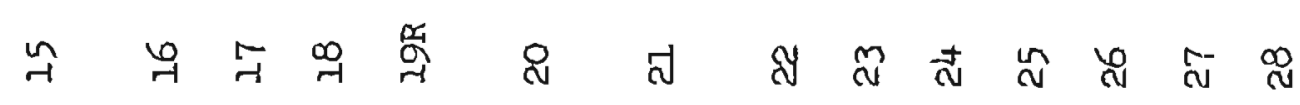




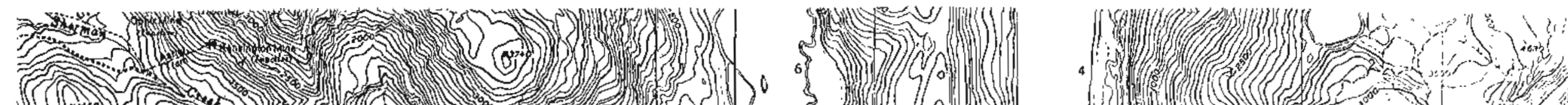

$\sqrt{(m)}=3$

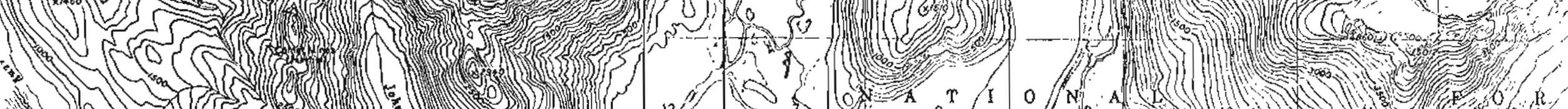
16) W 11 . (1) (1)

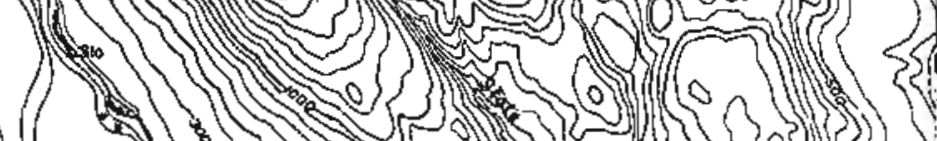
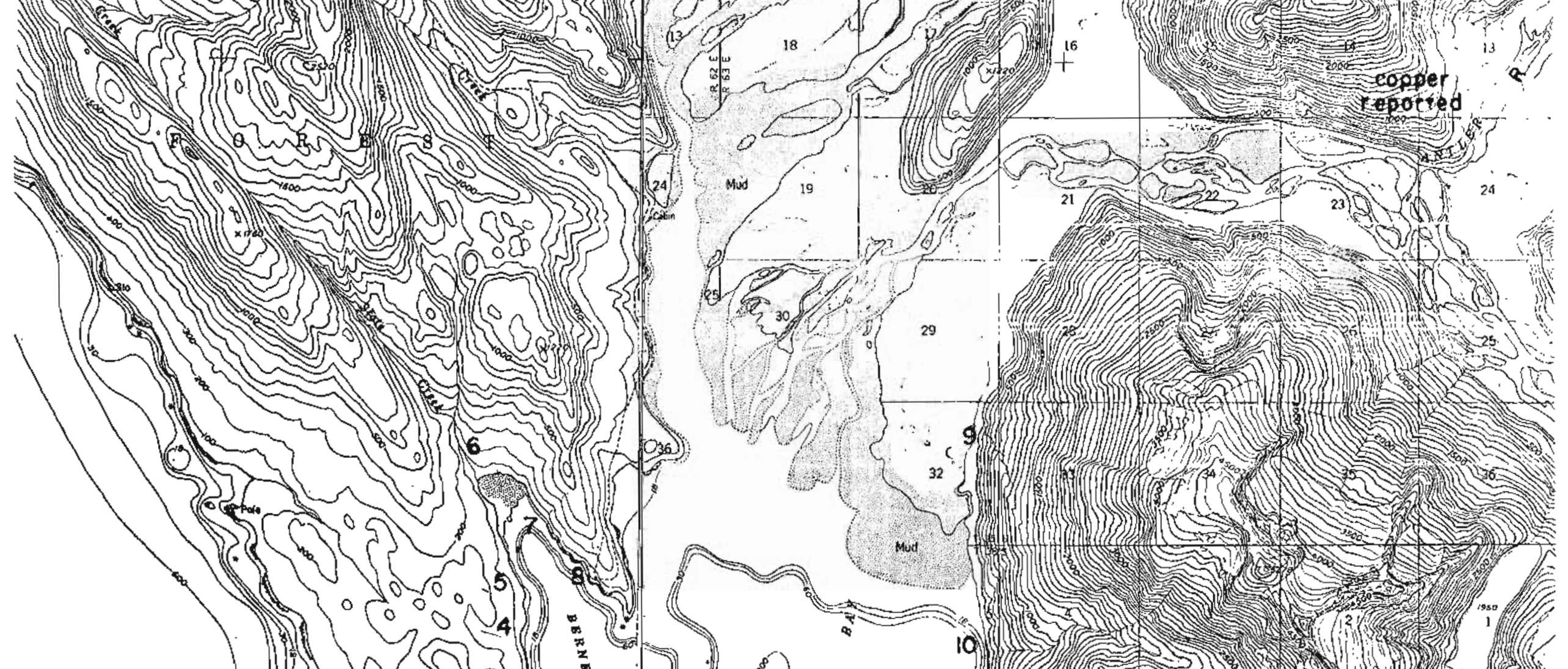

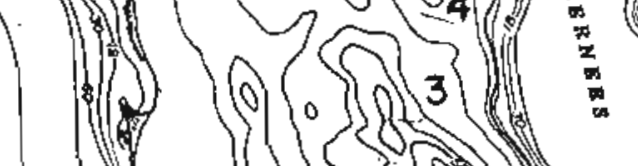

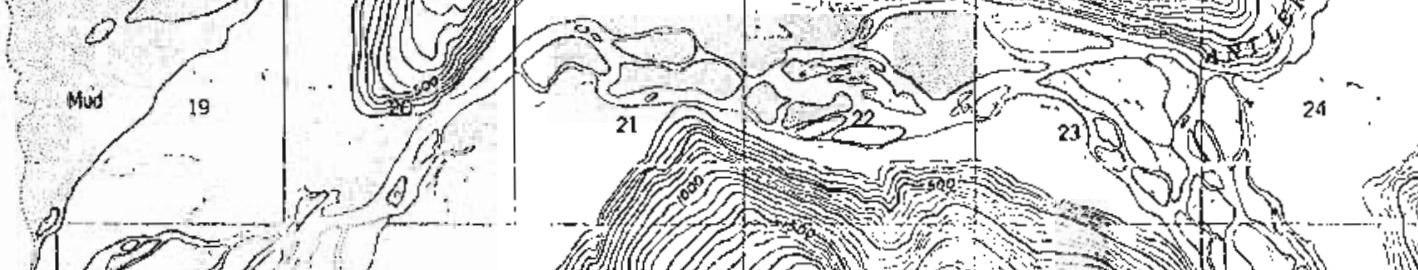
(1) auariz diorite 10
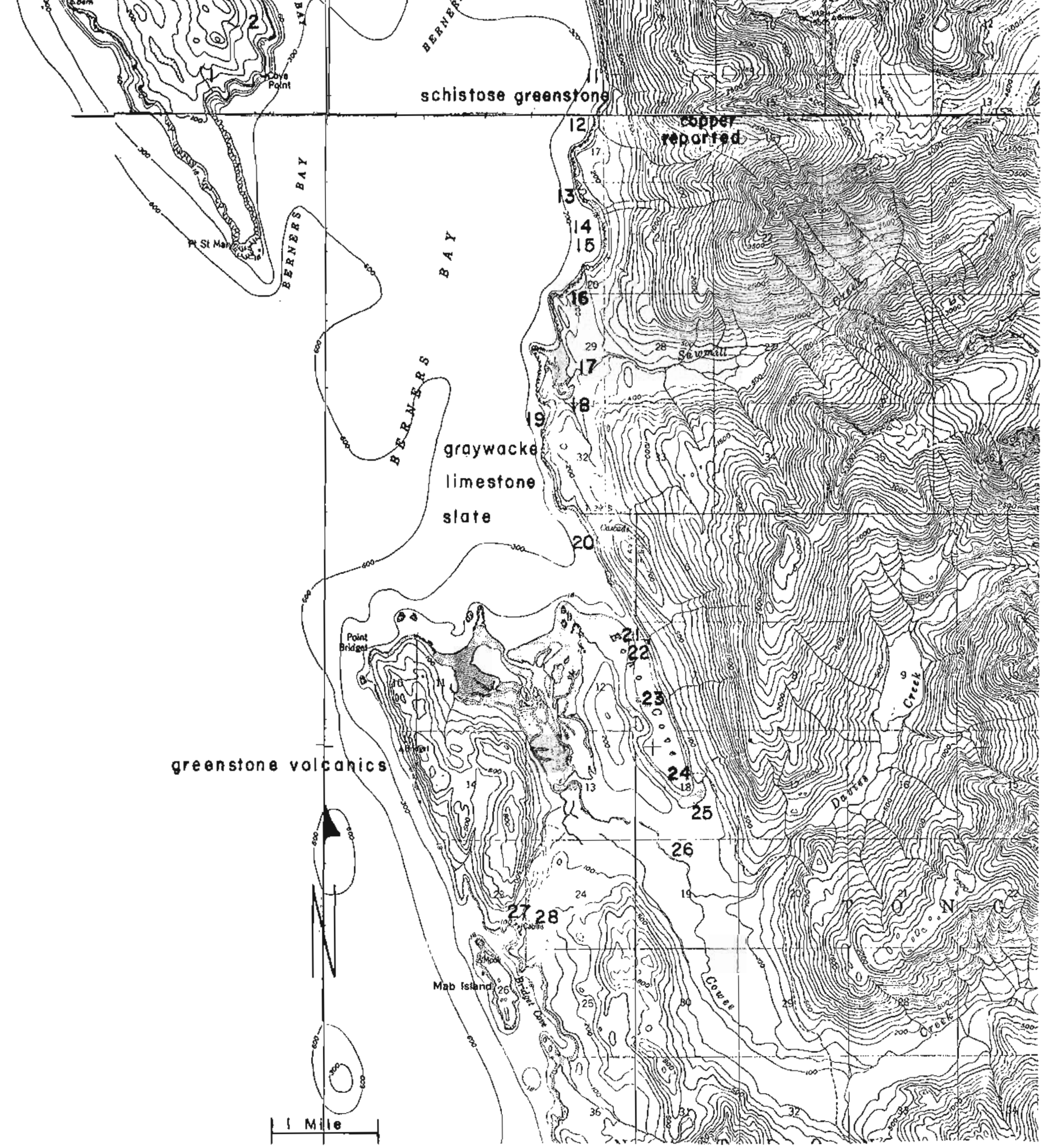
Six stream sediment samples were taken in the vicinity of the Taku River, thirty miles northeast of Juneau.

Several lead, zinc, copper, silver and gold prospects occur a few miles east of the border on the Canadian side.

Early U.S. Geological survey maps show this particular area as being part of the Coast Range batholith but detailed geologic mapping has not been done. The Canadian Department of Mines and Resources, Geological Survey Memoir 248 indicates that bedrock at the border in the vicinity of the sittakanay River and Wright Glacier 1s Paleozoic schist, quartzite, argilitte, and slate with minor intrusions. The intrusive in this area is quartz monzonite. The eastern limit of the Coast Range batholith is probably near the western part of the accompanying map.

Conslderably more work must be done before the mineral potentłal of this geologically favorable area can be determined. The rather high molybdenum content of samples 3 and 4 , in an area where metasediments are believed to be intruded by quartz monzonite, is interesting. 


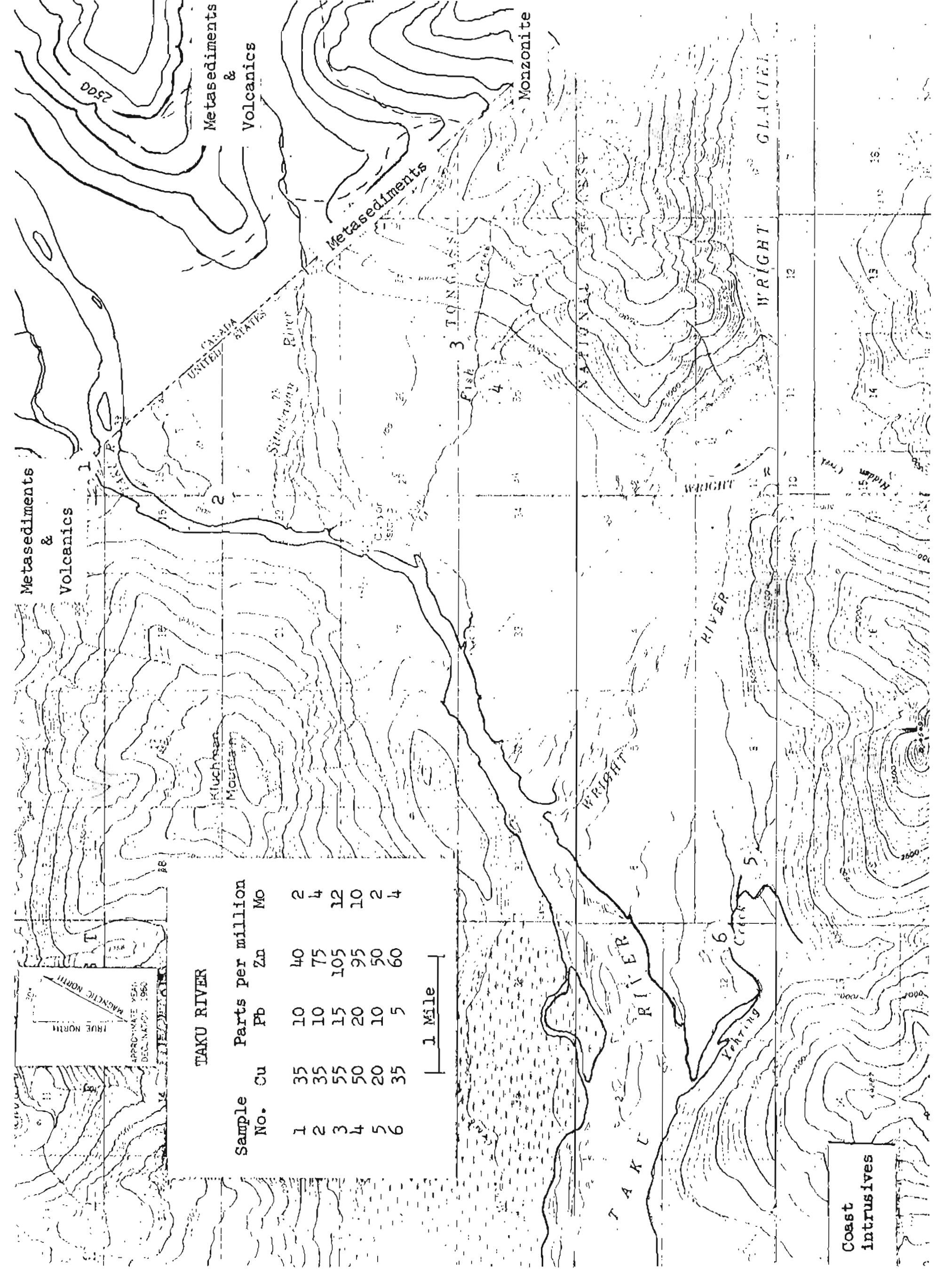


The Mansfield Peninsula is the northernmost part of fidmiralty Island and is approximately 20 miles west of Juneau. Gold was first discovered at Funter Eay in 3887 ; several small mines were active in the area for several years afterwards. Gold was discovered at Hawk Inlet in 1919 and there was some production from a large quartz vein.

More recently, activity has centered on the copper nickel deposit of the Fimiralty Mlaska Gold Mining Corporation at Eunter Bey. This deposit was drilled and tunneled under DNEA Loan provisions from 1951 to 1956. It has been mapped by the U.G. Geological survey and sampled by the U.S. Eureau of Mines. Pssays indicated values of $0.5-1.0 \%$ copper and similar values of nickel.

\section{Geology}

The Mansfield Peninsula has been described in part in several J.S. Geological survey publications. The most comprehensive of these are Bulletins 287, "The Juneau Gold Belt"; 714, "Mineral Resources of Alaska, 1919 and 1924"; 897-D, "Nickel Content of an Alaskan Basic Rock"; 936-0. "Nickel-Copper Deposit at Iunter Bay, Admiralty Island, Alaska"; 1155, "Contributions to Economic Seology of Alaska"; and 1181-R "Reconnaissance Geology of Admiralty Island, Alaska". U.s. Bureau of Mines publication RI 3950 contains sample information on the copper-nickel deposit. The copper-nickel deposit is described (Barker, Bulletin 1155) as being a gabbro pipe underlain by black graphitic phyllite with interlayered quartz-sericite-biotice schist and green schist. The Peninsula is predominantly Devonian schists with interbeds of marble. The schist varies from calcareous to graphitic, which is frequently pyritizea. Volcanic rocks, argiliite, chert, slate, and graywacke occur on the east shore, while a foliated quarta diorite pluion forms the west coast of the peninsulz.

Geocliemical Investigation

A tokal of 27 stream sediment samples were taken from streams draining into Funter Bay, Flawk Inlet, and along the east shore of Mansfiela veninsula. The streams sampled headed generally in the vicinity of Mt. Robert Barron. Inalyses of these samples indicate that streams draining the part of funter Bay in which the existing coppernickel deposit is located contain from 20 to $55 \mathrm{ppm}$ copper, from 75 to 135 ppm zinc, and from 45 to $70 \mathrm{ppm}$ nickel, none of which are considered to be anomalous. 
surprisingly, the only nickel anomalies were found south of Funter Bay in Hawk Inlet at map locations 9 to 13, where no nickel mineralization has been reported. This group of samples is also highly anomalous in $z$ inc and probably in silver. Samples at sites 11 and 12 contained 3.0 and 2.5 ppm silvex respectively.

\section{Prospecting}

Sample 12, which was taken from a small stream, is very high in zinc and nickel and carries lead in anomalous quantity. The topography suggests that sample site 12 lies on a southwesterly trending geologic structure (cross fold or shear zone) that could contain the source of the anomalies found in samples 10 and 11 .

The steep stream at site 12 should be followed up the hill, with careful attention paid to the possibility of float in the stream bed. soil samples should be taken northerly along the hill, and soll and gravel should be panned to detect the presence of sulphides or gold.

The headwaters of the streams sampled at sites 10 and 11 cut the hypothetical southweaterly geologic structure and should be followed by sampling of stream gediments and soils, and by panning. 


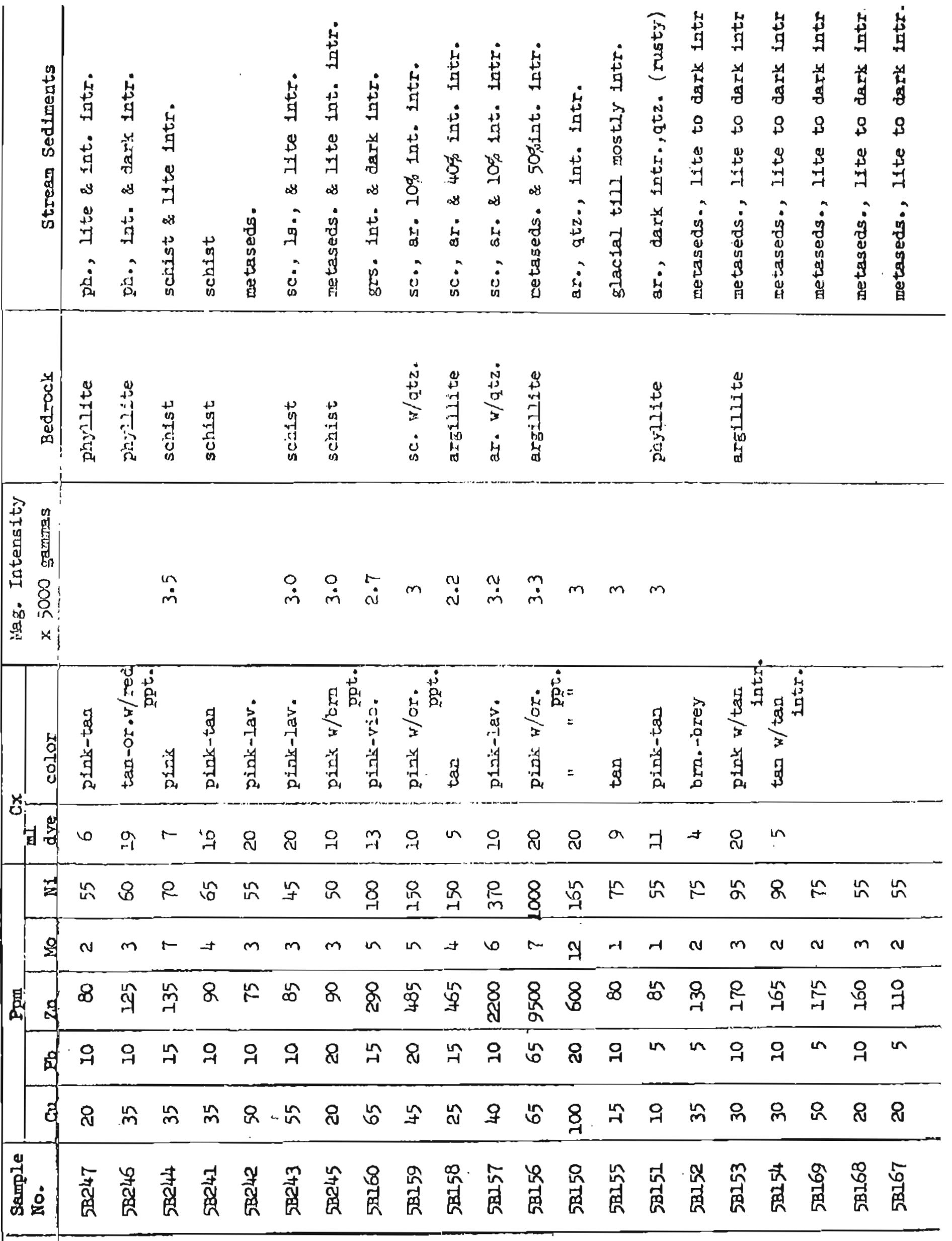

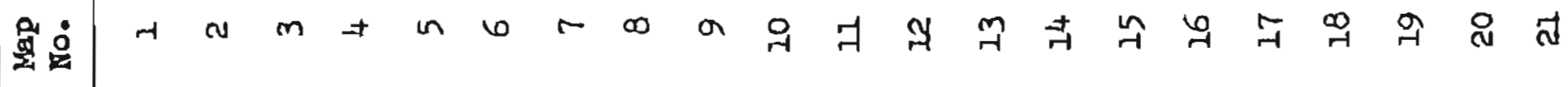




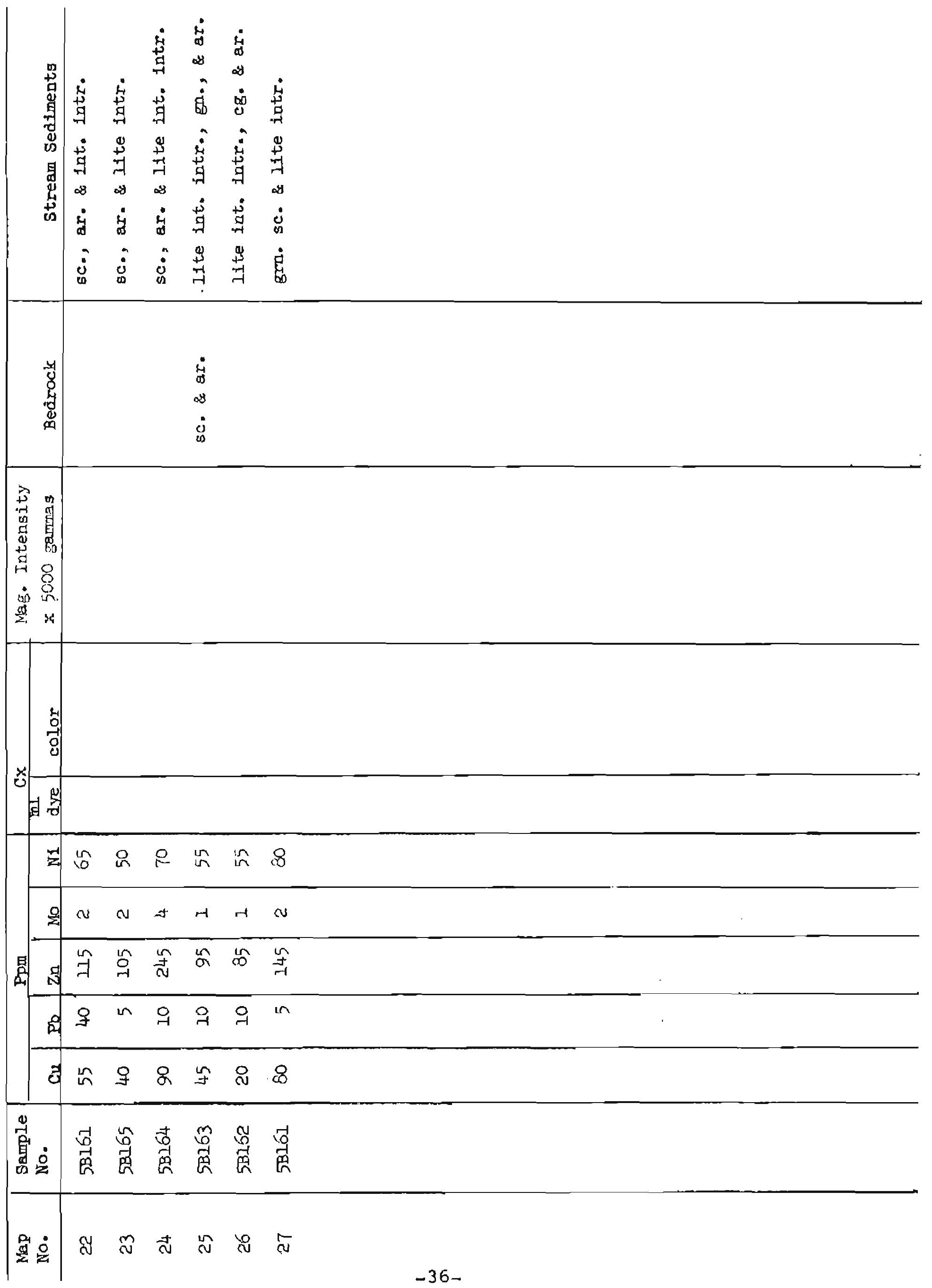




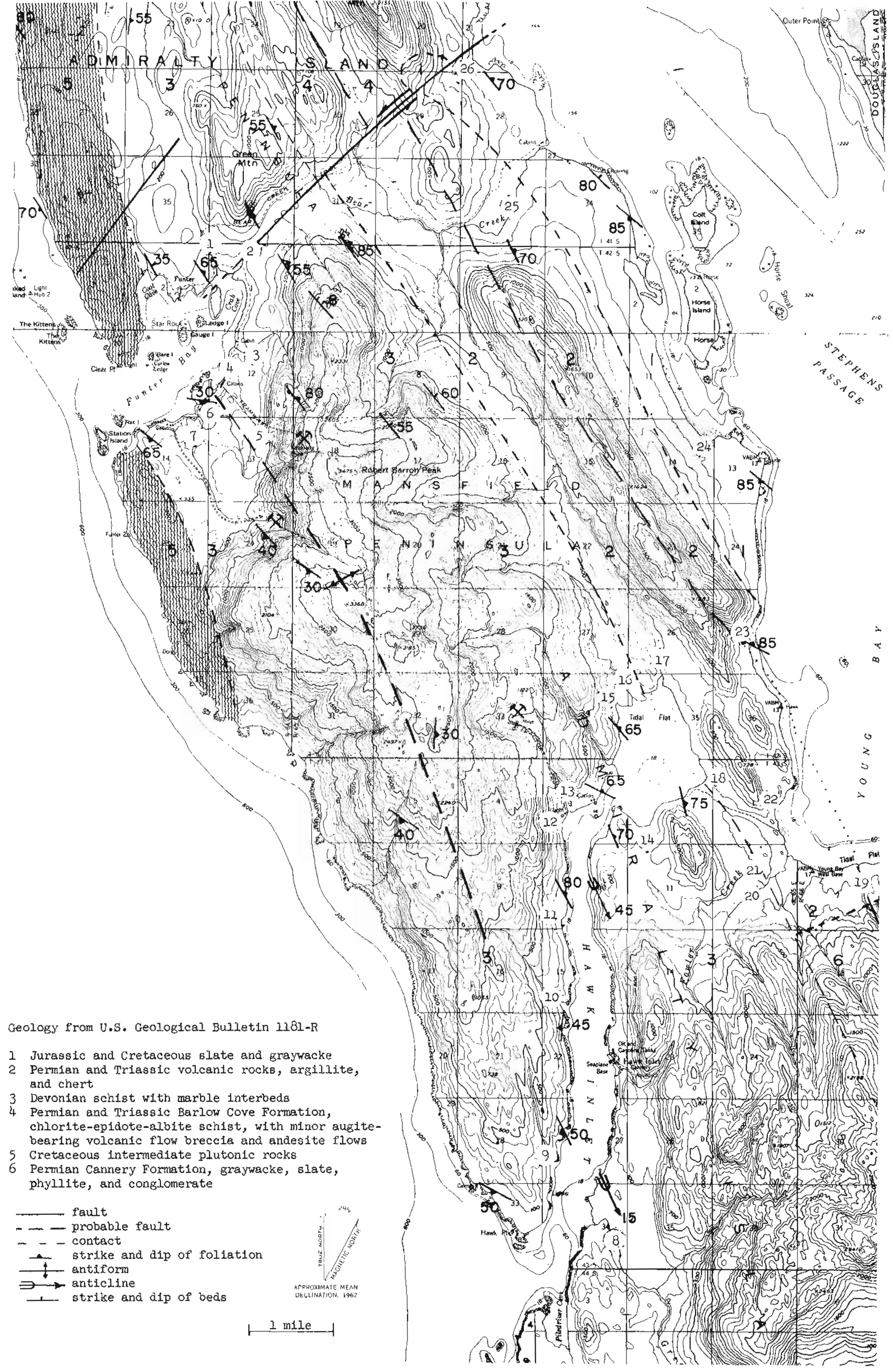


Tenakee Inlet, on the east side of Chichagof Island 50 mileg southwest of Juneau, is about 40 miles long. At the town of Tenakee, a hot spring has been in use since the late $1800^{\prime} \mathrm{s}$. Early U.S. Geological survey bulletins mention two nickel prospects east of the town. Norite is reported on the west side of the Inlet near its head. The norite is mentioned as being similar to that found on the west coast of Chichagof Island where it is known to contain copper and nickel. These reports led to the present investigation.

Geology

The accompanying copy of a portion of U.S. Geological Survey Map I-388 shows that Tenakee Inlet is an area where Devonian argillite, graywacke, and limestone have been intruded by a wide variety of igneous rocks. The age of the intrusives varies and for the most part is unknown. The prospects east of the town consist of mineralized dikes of mafic rocks near a granodiorite intrusive. The norite body reported in the old bulletins is shown on the west side near the head of the Inlet. Petrographic analyses of samples taken in and adjacent to the norite indicate the norite has in places been metamorphosed to a hornblend gneiss and contains less than $0.1 \%$ copper and zinc. Sample 5B205 contained 2 to 10 percent pyrrhotite but no nickel.

\section{Geochemical Investigation}

Sixty-six stream sediment samples were taken. Nine of these were from the watershed containing the prospects east of the village and thirteen from the watershed containing the norite body. Analyses did not show anomalous amounts of coppex, zinc, or nickel.

A single high lead analysis was reported from sample site 22 at the head of the Inlet. A re-assay of this sample revealed that it not only contained high lead but also high silver ( $3 \mathrm{ppm}$ ). The analysis also showed much iron and either bismuth or thallium.

The stream is 8 to 20 feet wide, and about lith miles long and heads on a steep mountain slope. It apparently heads along the contact between Devonian marble and hornfels where these sediments form a roof pendant in a diorite and tonalite intrusion.

The target area could be narrowed by geochemical sampling up the stream from its confluence with the main river. 
Samples 55 to 58 in Crab Bay indicate, in cold extractable tests, the presence of metals other than those tested for in the laboratory.

The rock and stream sediment samples taken in the vicinity of the norite body did not suggest the presence of appreciable amounts of nickel or copper. 


\begin{tabular}{|c|c|c|c|c|c|c|c|c|c|c|c|c|c|c|c|c|c|c|c|c|c|}
\hline 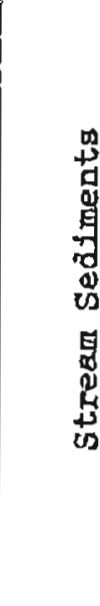 & 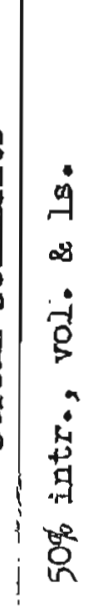 & di & 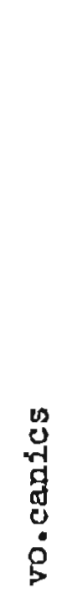 & 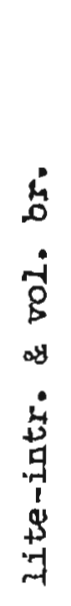 & 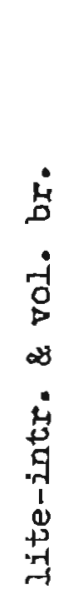 & 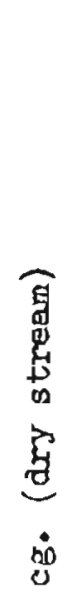 & 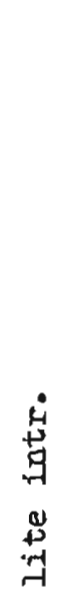 & 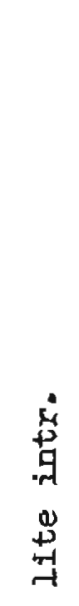 & 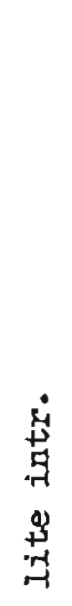 & 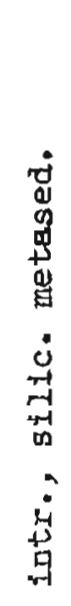 & 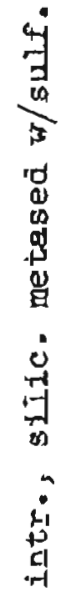 & 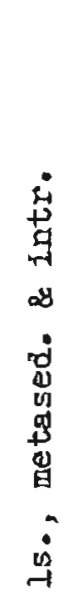 & 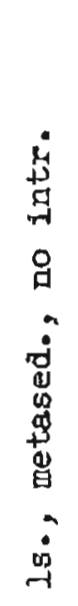 & 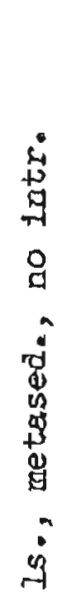 & 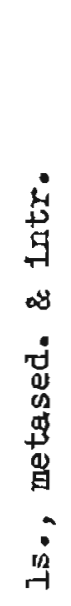 & 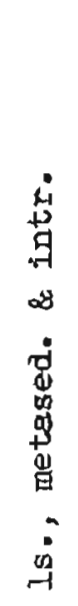 & 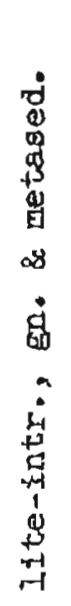 & 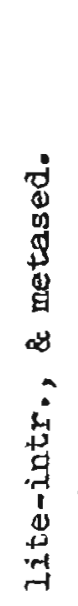 & 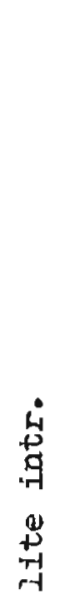 & 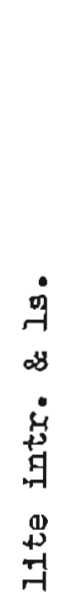 & 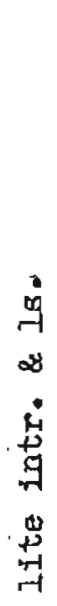 \\
\hline 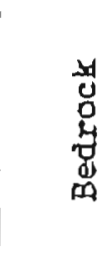 & 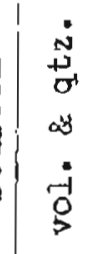 & & $\stackrel{d j}{g}$ & & & & 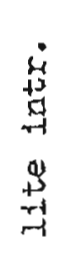 & 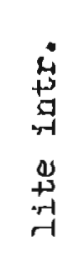 & & & & 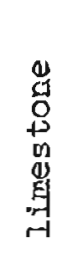 & & & & & 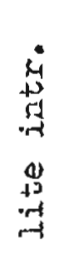 & 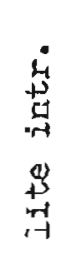 & 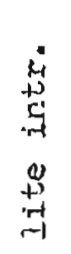 & & 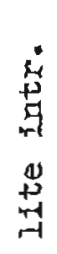 \\
\hline 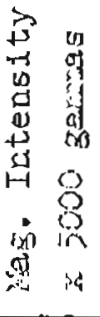 & & $m$ & & & & & & & & & & & & & & & & & & & \\
\hline $\begin{array}{l}. \\
0 \\
0-1 \\
0 \\
0\end{array}$ & 莡 & $\stackrel{\substack{a \\
a j}}{a j}$ & ii & $\stackrel{9}{\$}$ & 9 & & 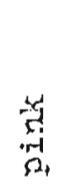 & & iy & & & $\underset{g}{5}$ & 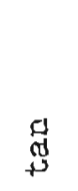 & of & & 马ึ & $\underset{7}{9}$ & & 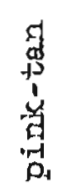 & & \\
\hline 直 & $N$ & $\sim 1$ & $\infty O$ & $\Rightarrow$ & $H$ & & in & & $m$ & & & $r$ & $H$ & $r-1$ & & $r-1$ & -1 & & $m$ & & \\
\hline$z$ & 9 & in & 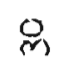 & $\stackrel{n}{r}$ & $\ddot{6}$ & in & in & 9 & in & 8 & $\ln$ & 8 & in & 8 & $\hat{0}$ & in & in & 织 & 昌 & 9 & เి \\
\hline$\frac{0}{2}$ & $\sim$ & \pm & \pm & 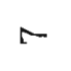 & in & in & 10 & 6 & in & \o & $m$ & $\neq$ & in & 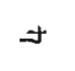 & in & in & un & $\infty$ & $m$ & + & $\infty$ \\
\hline 罟 & 8 & $\stackrel{n}{\infty}$ & 윰 & $\stackrel{8}{8}$ & ్ㅗㄱ & 8 & 8 & in & \& & $\stackrel{n}{n}$ & 8 & $\stackrel{L}{\alpha}$ & 吊 & $R$ & $q$ & 8 & $\stackrel{\leftrightarrow}{\infty}$ & 88 & 8 & 음 & 8 \\
\hline מ. & $\stackrel{\circ}{\circ}$ & in & in & 尺 & $\tilde{r}$ & $\stackrel{0}{\rightarrow}$ & in & 우 & $\stackrel{\text { fr }}{r}$ & 足 & in & 8 & 아 & $\stackrel{\circ}{\circ}$ & $\stackrel{n}{n}$ & $\stackrel{-}{\circ}$ & $\stackrel{\circ}{\circ}$ & $\underset{-1}{n}$ & $\stackrel{n}{n-1}$ & $\stackrel{9}{\circ}$ & $\stackrel{\circ}{\rightarrow}$ \\
\hline है & $\tilde{r}$ & હે & un & $\stackrel{m}{m}$ & 8 & 吕 & $\stackrel{n}{-1}$ & 암 & $\stackrel{\leftrightarrow}{N}$ & $\stackrel{m}{m}$ & $\stackrel{\mathrm{m}}{ }$ & $\stackrel{\text { In }}{m}$ & 9 & 9 & 옥 & 只 & m & $\stackrel{\operatorname{Ln}}{c}$ & $\stackrel{\circ}{\mathrm{N}}$ & $\hat{c}$ & 옥 \\
\hline 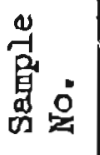 & $\begin{array}{l}\stackrel{m}{\vec{r}} \\
\stackrel{\leftrightarrow}{n}\end{array}$ & 点 & $\frac{\stackrel{N}{r}}{q R}$ & $\begin{array}{l}\vec{E} \\
\stackrel{\vec{A}}{\mathrm{C}}\end{array}$ & 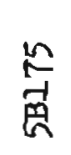 & 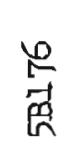 & E & 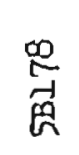 & 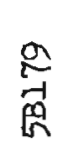 & $\begin{array}{l}8 \\
-1 \\
\stackrel{n}{R}\end{array}$ & $\begin{array}{l}\text { 古 } \\
\text { 足 }\end{array}$ & $\begin{array}{l}\underset{N}{\infty} \\
-1 \\
\mathbb{R}\end{array}$ & 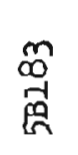 & $\begin{array}{l}\text { む゙ } \\
\text { 蛋 }\end{array}$ & 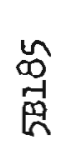 & 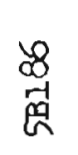 & 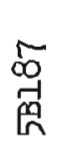 & $\begin{array}{l}98 \\
\text { 足 } \\
\text { 品 }\end{array}$ & $\begin{array}{l}8 \\
8 \\
I_{1}\end{array}$ & $\begin{array}{l}\stackrel{8}{\Omega} \\
\text { 㽍 }\end{array}$ & $\begin{array}{l}\vec{\sigma} \\
\vec{\sigma} \\
\overrightarrow{R^{2}}\end{array}$ \\
\hline$\stackrel{\mathrm{g}^{\prime}}{\mathrm{O}}$ & $H$ & o & $m$ & \pm & in & 0 & $N$ & $\begin{array}{c}\infty \\
-30\end{array}$ & $a$ & 욱 & 7 & $y$ & $m$ & $\vec{\sim}$ & $\stackrel{n}{\sim}$ & $\stackrel{\leftrightarrow}{r}$ & 5 & $\stackrel{\infty}{\infty}$ & $\stackrel{\vec{r}}{ }$ & 尺े & - \\
\hline
\end{tabular}




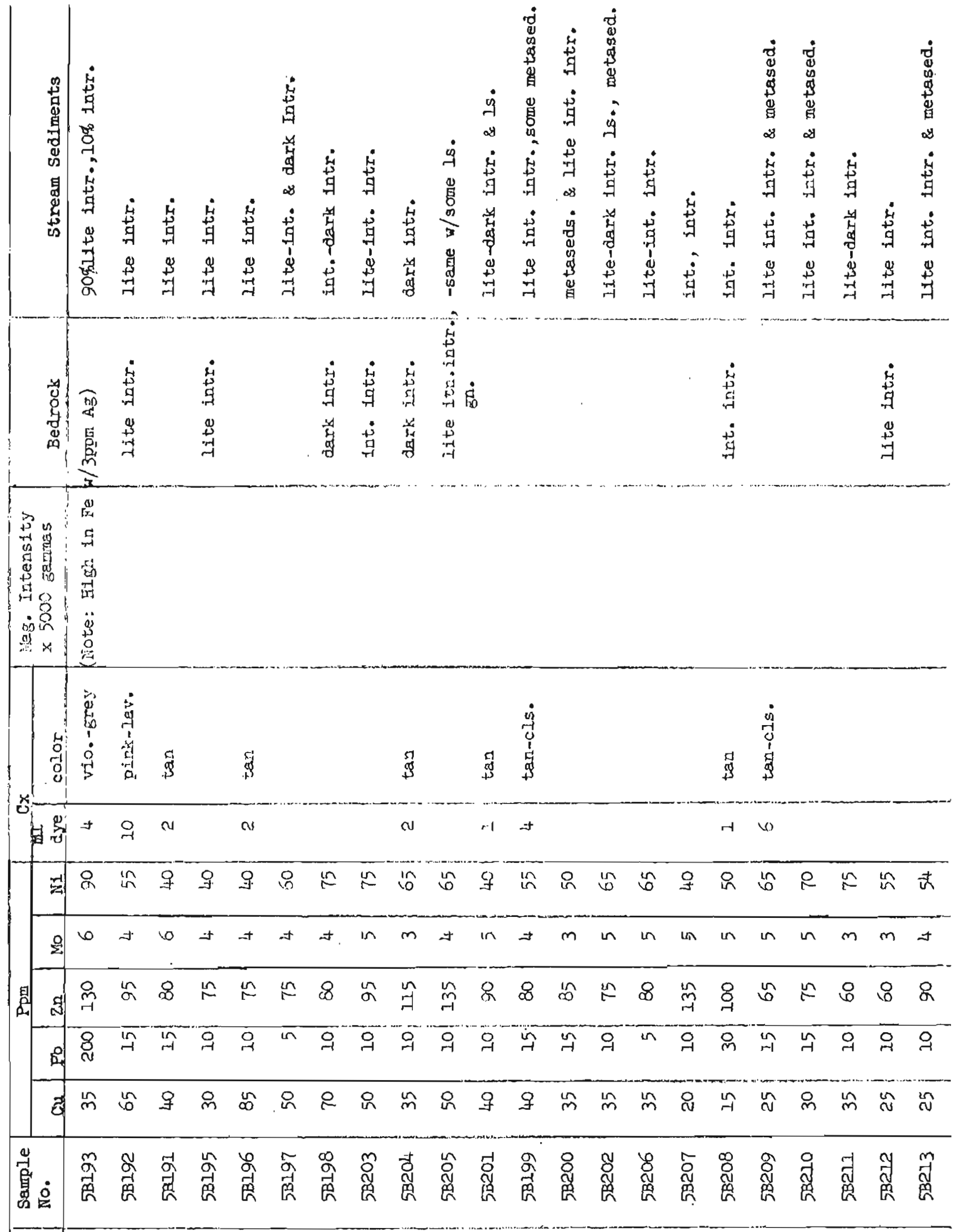

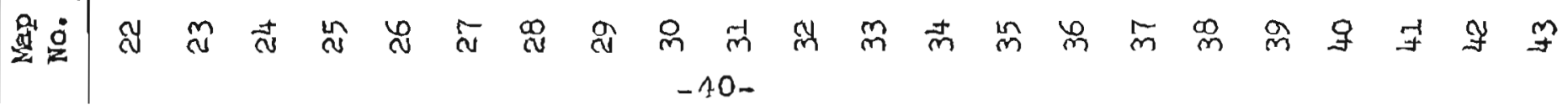




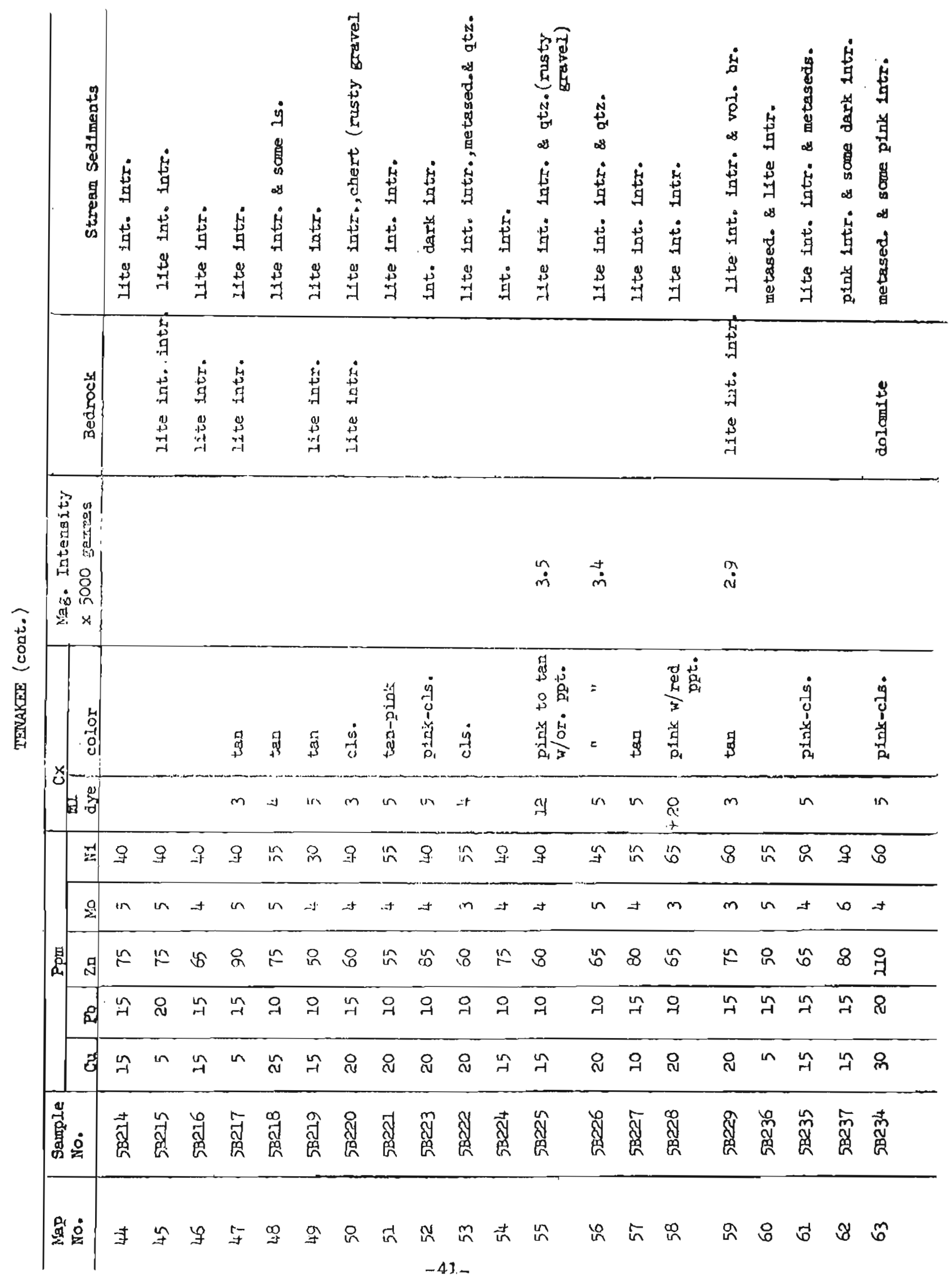




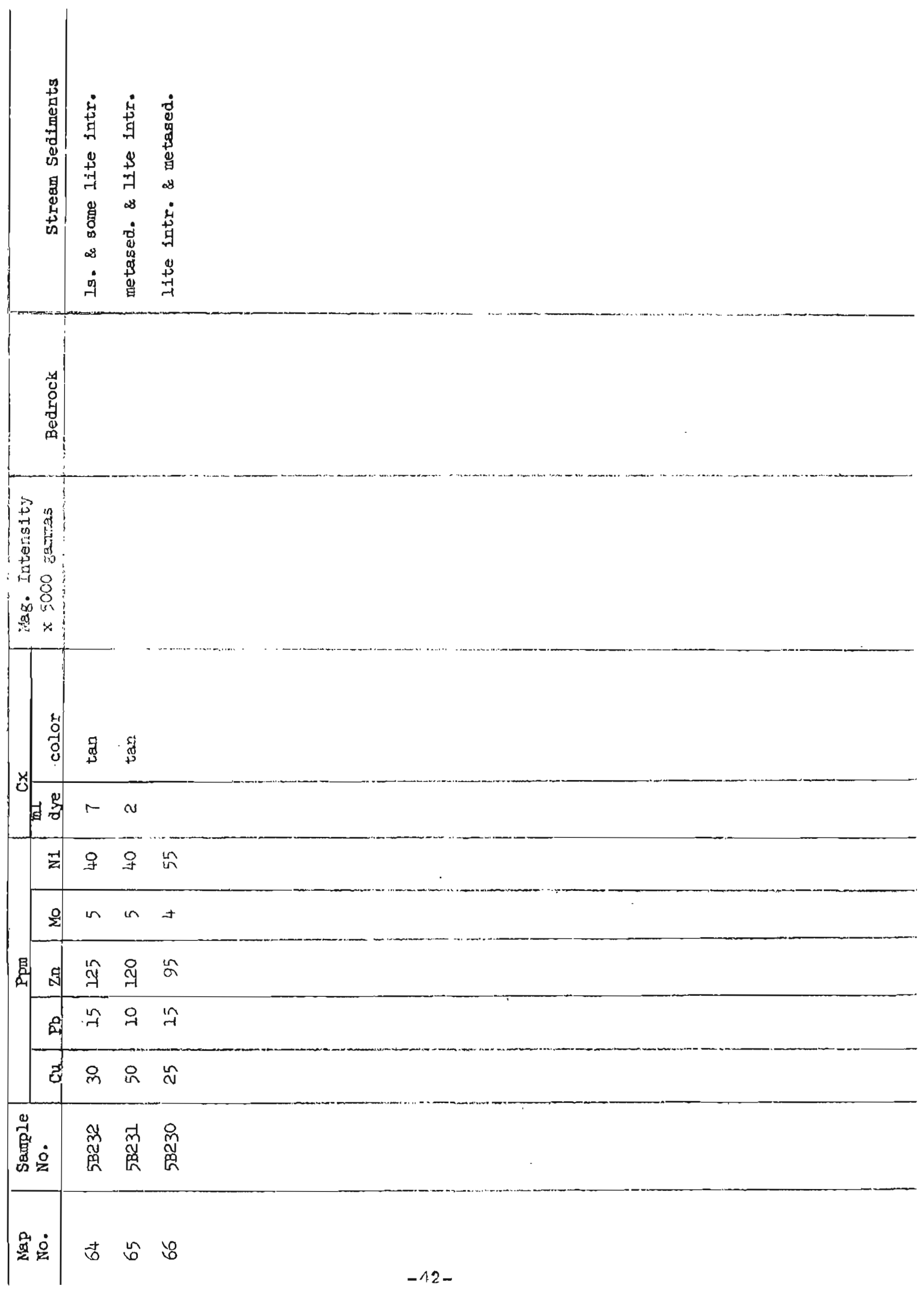


Kelp Bay is on the northeast portion of Baranof Island, 75 miles southwest of Juneau. There are no reported prospects in the area. This investigation was made because of the interesting geology mapped by the U.S. Geological Survey and published in Map I-111, "Reconnaissance Geologic Map of Baranof and Kruzof Islands, Alaska"; Map I-388, "Reconnaissance Geologic Map of Chichagof Island and Northwestern Baranof Island, Alaska"; and Bulletin 1141-0, "Reconnaissance Geology of Northern Baranof Islend. AJaska".

It was noted on Map I-388 that several samples of bedrock taken in the vicinity of Kelp Bay indicated the presence of sulphides on the southeast shore of The Basin, the southwest shore of Catherine Island, and near Cosmos Cove. An intrusive granodiorite is shown at Catherine Island and south of Kasnyku Bay. Sedimentary, volcanic, and intrusive rocks are metamorphosed and highly silicified. Intense shearing has occurred along the fault between Baranof and Catherine Isiands.

\section{Geochemical Investigation}

A total of 49 stream sediment samples were taken during the course of this investigation. Samples 46 to 48 , taken along a four-mile distance on the northeastern shore of Poxtage Arm and Kelp Bay, are anomalous in nickel. The rocks dxained by the streams sampled are amphibolite, hornblende gneiss, gabbro, tonalite, and diorite. Unfortunately. most of the streams in this area were dry at the time of examination. This resulted in an insufficient number of samples taken.

Since a nickel anomaly exists, and the known rock types may be favorable for the occurrence of nickel ore bodies, the area merits further attention. In particular. the better developed drainare system that flows easterly ano northeasterly from the intrusive mass on catherine Island snould be tested. 


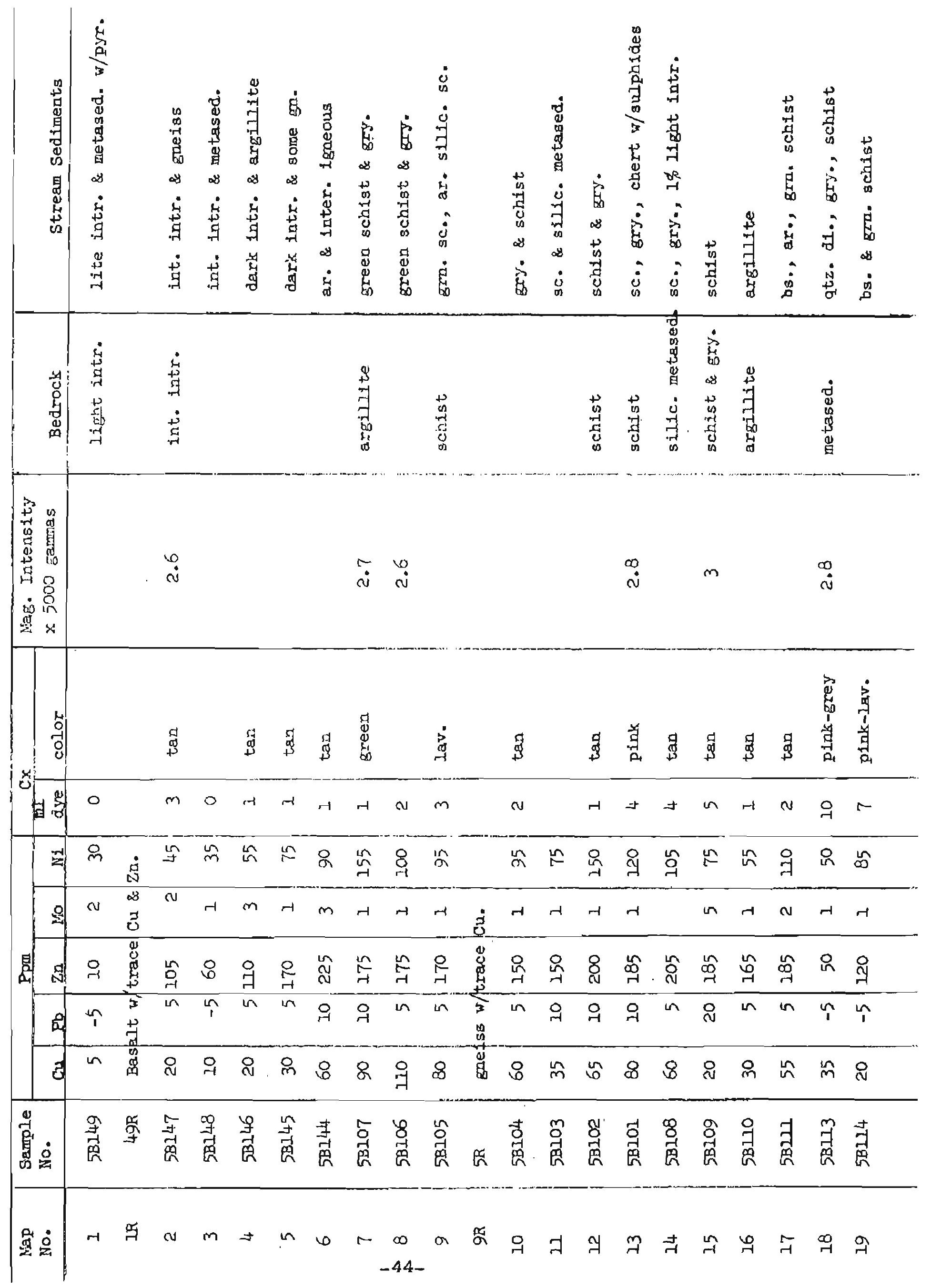




\begin{tabular}{|c|c|c|c|c|c|c|c|c|c|c|c|c|}
\hline \multirow{2}{*}{\multicolumn{2}{|c|}{$\begin{array}{l}\text { Mep } \\
\text { No. }\end{array}$}} & \multirow{2}{*}{$\begin{array}{l}\text { Semple } \\
\text { No. }\end{array}$} & \multicolumn{5}{|c|}{ Ppтा } & \multicolumn{2}{|c|}{$\mathrm{Cx}$} & \multirow{2}{*}{$\begin{array}{l}\text { Mag. Intensity } \\
\times 5000 \text { sannas } \\
\end{array}$} & \multirow[b]{2}{*}{ Becrock } & \multirow[b]{2}{*}{ Strean Sediments } \\
\hline & & & Sh. & Plo & 虹 & Mo & $\mathrm{N1}$ & dye & color & & & \\
\hline & 20 & $5 \mathrm{~B} 115$ & 35 & .5 & 105 & $I$ & 65 & 13 & Dink-lav. & & & gry*, b.s.., ar. \& lite intru. \\
\hline & 22 & $5 B 119$ & 120 & 10 & 200 & 1 & 95 & 4 & $\tan$ & & argillite & argillite \\
\hline & $22 \mathrm{R}$ & $19 R$ & gne & is $\mathrm{w} /$ & trace & $\mathrm{Cu}$. & & & & & & \\
\hline & 24 & $5 \mathrm{~B} 316$ & 50 & 10 & 200 & 1 & 90 & 7 & $\tan$ & & chert & argillite \& chert \\
\hline & 25 & 58112 & 90 & 5 & 165 & 1 & 115 & 4 & pinctan & 3 & & grs., ar. \& gry. \\
\hline & 26 & 58126 & 40 & 10 & 200 & 1 & 70 & 2 & $\tan$ & 3 & schist & green sebtst \\
\hline & 27 & $5 \mathrm{~B} 124$ & 65 & 10 & 190 & 2 & 50 & 3 & pale $\tan$ & & argillite & argillite \\
\hline is & 28 & 58125 & 45 & 5 & 170 & 1 & 90 & 5 & Lav. & & argillite & argillite \\
\hline & 29 & $5 \mathrm{~B} 223$ & 25 & 20 & 245 & 1 & 75 & 10 & pink-tan & 2.6 & sh. \& se. & shale \& schist \\
\hline & 30 & $5 \mathrm{~B} 122$ & 35 & 5 & 190 & $\lambda$ & 65 & 14 & pink-tan & 2.8 & ar. $w / q t z$. & argilitte, greenstone \\
\hline & 31 & $5 B 121$ & 50 & 10 & 200 & 1 & 75 & 2 & pink & 2.6 & gry. & gry. \& argillite \\
\hline & 32 & $5 B 120$ & 60 & 5 & 170 & 1 & 120 & 4 & pink-lav. & & & grs. \& sone jasper, gry. \\
\hline & 33 & 58329 & 49 & 5 & 165 & 1 & 95 & 4 & $\tan$ & & . & sc. \& qtz. a. v/sulptides \\
\hline & 34 & $5 B 128$ & 25 & 5 & i65 & 1 & 95 & 3 & $\tan$ & & schist & schist \& gry. \\
\hline & 35 & $5 B 127$ & 55 & 5 & 190 & 1 & 75 & 2 & $\tan$ & & poyllite & ar., grs. sc., purpie sc. \\
\hline & 36 & 58139 & 30 & 10 & 240 & 2 & 100 & 0 & & & gro. schist & schist, argillite \\
\hline & 37 & $5 B 138$ & 25 & 5 & 275 & 2 & 90 & 2 & tan & & & gra/ scjost \& some jasper \\
\hline & 38 & $5 \mathrm{~B} 135$ & 30 & 5 & 160 & 5 & 115 & 10 & pink-tan & & & schist, ar., gry. \\
\hline & 39 & $5 \mathrm{Bl} 36$ & 30 & 5 & 160 & 3 & 135 & 3 & $\tan$ & & & schist \& metased. \\
\hline
\end{tabular}




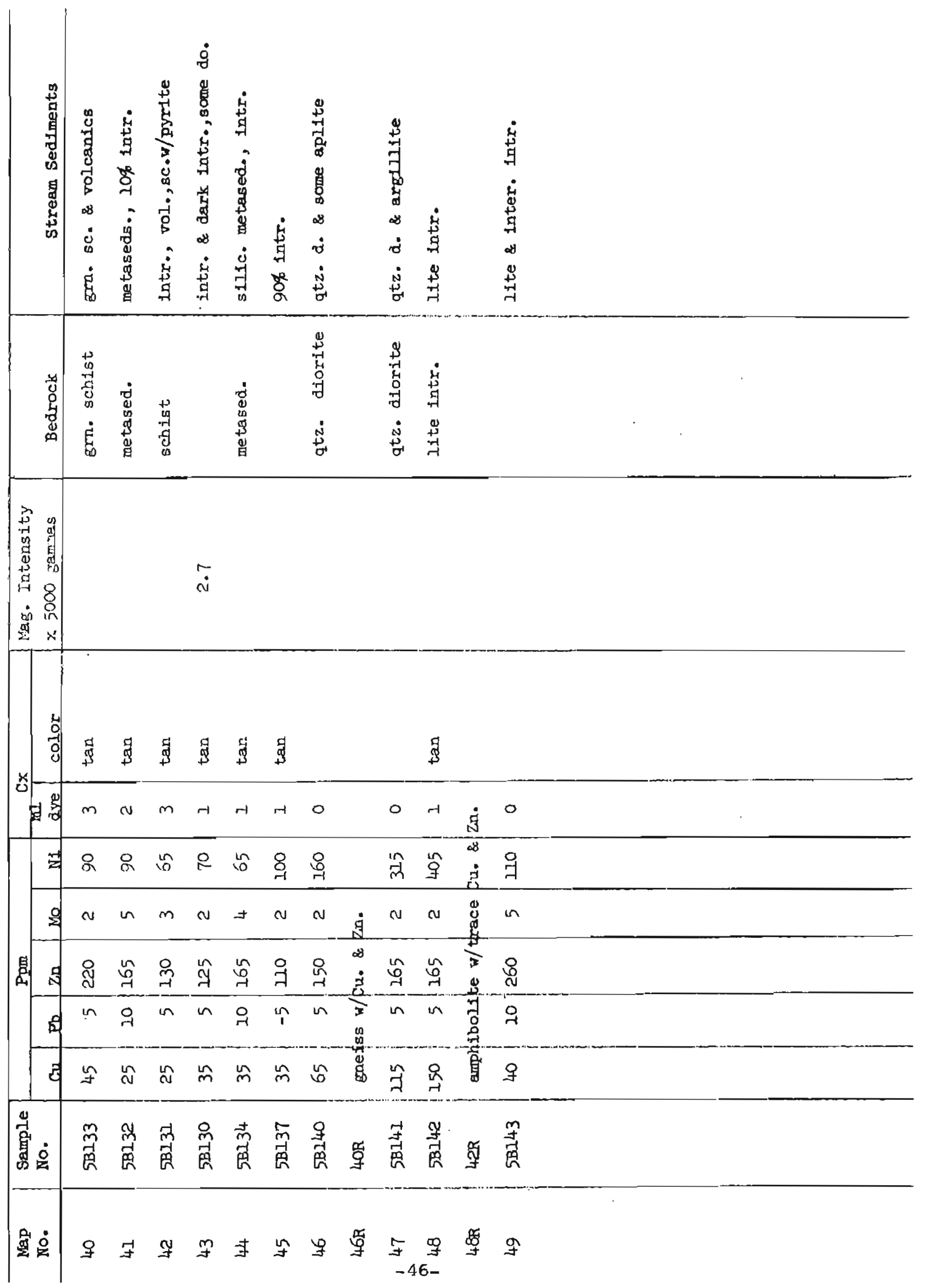


During 1964 and 1965, stream sediment samples were collected from most of the reasonably accessible streams which flow into Pybus Bay and Gambier Bay. A total of 157 samples have been analyzed for copper, lead, zinc and molybdcnum. The analyses point to four areas in which prospecting is warranted.

\section{Previous Work}

In 1904 the U.S. Geolcgical Survey reported on the Brown copper prospect on Cave Mountain (south of location 143 on the accompanying map) and on Gambier Mountain (north of location 146). Mention of these prospects is made in U.S.G.S. Bulletins 259 and 287 . Prospectors have reported copper at a few other locations especially in the area bounded by map locations 150 and 155 .

\section{Geology}

U.S. Geological Survey Bulletin 1178, stratigraphy and Petrography of the Pybus-Gambier Area by Robert A. Loney (1964) covers the geology of the area, the general features of which are shown on the accompanying map.

Geochemical work has drawn particular attention to the Hood Bay formation (shown as No. 7 on the accompanying map) and the Hyd formation (shown as No. 8 for the sedimentary section and No. 11 for the volcanic section).

The Hood Bay formation, which Ioney considers to be Devonian in age, consists of radiolarian chert and siliceous argillite with local limestone. calcareous argilizte, and fine-grained graywacke. Firely divided carbonaceous material and pyrite are common. Ioney believes that ancient volcanics were the source of the sediments, which were deposited in a restricted basin. No large intrusive masses are known to exist but dikes of intermediate composition have been found. There are a few basic lava flows.

The Hyd formation consists of a basal chert breccia with a dolomite or limestone matrix, a limestone member, and an argillite member. Basic volcanic flows are interfingered with the sediments and are, at places, the dominant rocks in the formation. Loney assigns the Hyd formation to the Triassic system.

\section{Geochemical Results}

Seven stream sediment samples (map locations 12 to 18 ) were taken from streams which drain an area apparently underlain entirely by rocks of the Food formation. These seven samples average 136 ppm copper, 19 ppm 
lead, $289 \mathrm{ppm}$ zinc, and $12 \mathrm{ppm}$ molybdenum. Contiguous streams from map location 13 to 16 average $162 \mathrm{ppm}$ copper, $20 \mathrm{ppm}$ lead, 302 ppm zinc, and $13 \mathrm{ppm}$ molybdenum. Apparently the Hood formation, or parts of it, have an anomalously high content of copper, zinc, and possibly molybdenum.

In Gambier Bay, map locations 107 and 111 average 52 ppm copper, 65 ppm lead, 321 ppm zinc, and 1 ppm molybdenum. The streams at these locations drain the Hyd formation below its contact with the Hood formation. which is folded sharply. The area also lies just south of the projected position of the Gambier Bay fault. zinc anö lead are present in anomalous quantities.

Where the Hyd formation is exposed on the north shore of Gambier Bay, the streams at map locations 150 to 154 average 117 pprn copper. 67 ppm lead, $783 \mathrm{ppm}$ zinc, and $13 \mathrm{ppm}$ molybdenum. Within the area covered there has been some prospecting for copper and nickel, but the stream sediments indicate that lead, zinc, and possibly molybdenum should be sought, as well as copper, which is present in anomalous quantity only at location 154. A specimen of dolomite breccia at location 152 carried only $10 \mathrm{ppm}$ in copper with quartz, pyrite, and fuchsite, a chrome-nickel mica. The specimen assayed $0.10 \%$ nickel and a trace of gold.

At map locations 94 to 97 the stream sediments average 55 ppm copper, 10 ppm lead, 298 ppm zinc, and le ppm molybdenum (sample 94 carried 28 ppm molybdenum). These streams drain an area underlain by schists and phyllites of the Gambier Bay formation. which, at the sample locality, contained considerably more mica than was observed elsewhere.

\section{Prospecting}

The Hood Bay formation of carbonaceous chext and argillite, in the northwestern part of Pybus Bay, appears to carry anomalous amounts of copper, zinc and possibly molybdenum. These metals may be widely distributed in the rocks, but concentsation in one or more favorable beds or structures is possible.

At map location 16 a small stream with anomalous copper flows over carbonaceous argillite. This stream appears to have its origin along an east-west fault that offsets a 30 foot wide andesite dike. Near the fault, the argillite is badly sheared and carries considerable pyrive. The chert is recrystallized. It is suggested that the stream be followed from location 16 southwesterly for a half mile or less by taking stream sediment samples for goochemical tests in the field, with laboratory tests at a later date, and that chip samples of bedrock be taken frequently for laboratory analysis. Bedrock should be examined carefully for the presence 
of finely divided sulphides, and assays should be made of samples that appear to contain sulfides or that show copper stains. It is possible that field testing of water for heavy metals may be a useful and rapid mathod of tracing the anomaly to its source.

At location 17 a large stream, about two miles long drains a basin underlain by rocks of the Hood formation. At its mourh this stream has a copper content of 130 ppm and a zinc content of 300 ppm. These quantities seem to be fairly high in relation to the size of the stream, indicating that investigation of this stream and its tributaries is warranted.

At locationg 13 and 14 , the stream sediments have anomalous amounts of copper, zinc, and nolybdenum. The streams are fairly short and should be followed.

In the southwestern portion of Gambier Bay, map locations 107 to 111 are on small, steep streams that cross the liyd formation, which, at this place, consists almost entirely of limestone with some andesite intrusions (possibly flows). The streams have anomalous contents of lead and zinc.

The contact between the Hyd formation and the Gambier Bay formation apparently lies a short distance south of the shoreline but at an elevation between 300 feet and 600 feet. It is folded, probably faulted, and may be adjacent to the basal breccia member of the Hyd. The setting may be favorable for the existence of lead and zinc replacement bodies.

Since the hillside is very steep. the best access is up the stream along the fault at location 111. This should be followed to the contact between the limestone (or breccia) and the schist. This contact should then be followed easterly and southeasterly for about one-half mile.

The Hyd formation is well exposed on the noxth shore of Gamier Bay at locations 150 to 154. Copper and nickel prospects have been found in this area but little work has been done on them. Since geochemical tests show only one copper anomaly (at location 154) and all are high in lead. and zinc, it seems that lead-zinc orebodies are more likely to be found. It should be noted that the cold extractable test of sample 154 gave a precipitate that often indicates the presence of silver.

The best access is up the nose of the ridge from location 154 . The stream at this place lies in a long northwesterly trending cepression that probably marks the contact between the sedimentary and volcanic members of the Hyd formation. Apparently the contact is faulted and diorite in the creek may be derived from one or more small intrusions. 
The molybdenum and zinc anomaly at map location 94 to 97 on the west shore of snug Cove in Gambier Bay may or may not have importance. Sample 94, which carried $28 \mathrm{ppm}$ of molybdenum, was taken from a stream that drains from a probable northeasterly trending fault zone in soft, micaceous schists. There are no known intrusive masses nearby, but at locatjon 95 acidic igneous rocks and quartz are present in the stream bed. The stream at location 94 may be followed westerly for 500 to 600 seet to a point where the stream lies in the assumed fault. If there is evidence of acidic intrugives (such as granite), considerable quartz ox silicified schist, the search for molybdenum should be continued by stream sediment and soil analyses. Similarly, the stream from location 95 should be followed westerly.

On the ridge between the north and south arms of Gambier Bay, samples 131 an 133 show anomalous copper, apparently derived from a falrly narrow band of dolomite breccia that extends westerly from the beach at location 133 for two or three miles along the northern face of the ridge. The old Brown copper prospect was on this band and chalcopyrite may be found at the beach. Exposures are rare but the bed can be followed by intermittent patches of rusty soil. A lack of important copper anomalies from 135 to 143 discourages a belief that the breccia bed contains a large copper orebody. 


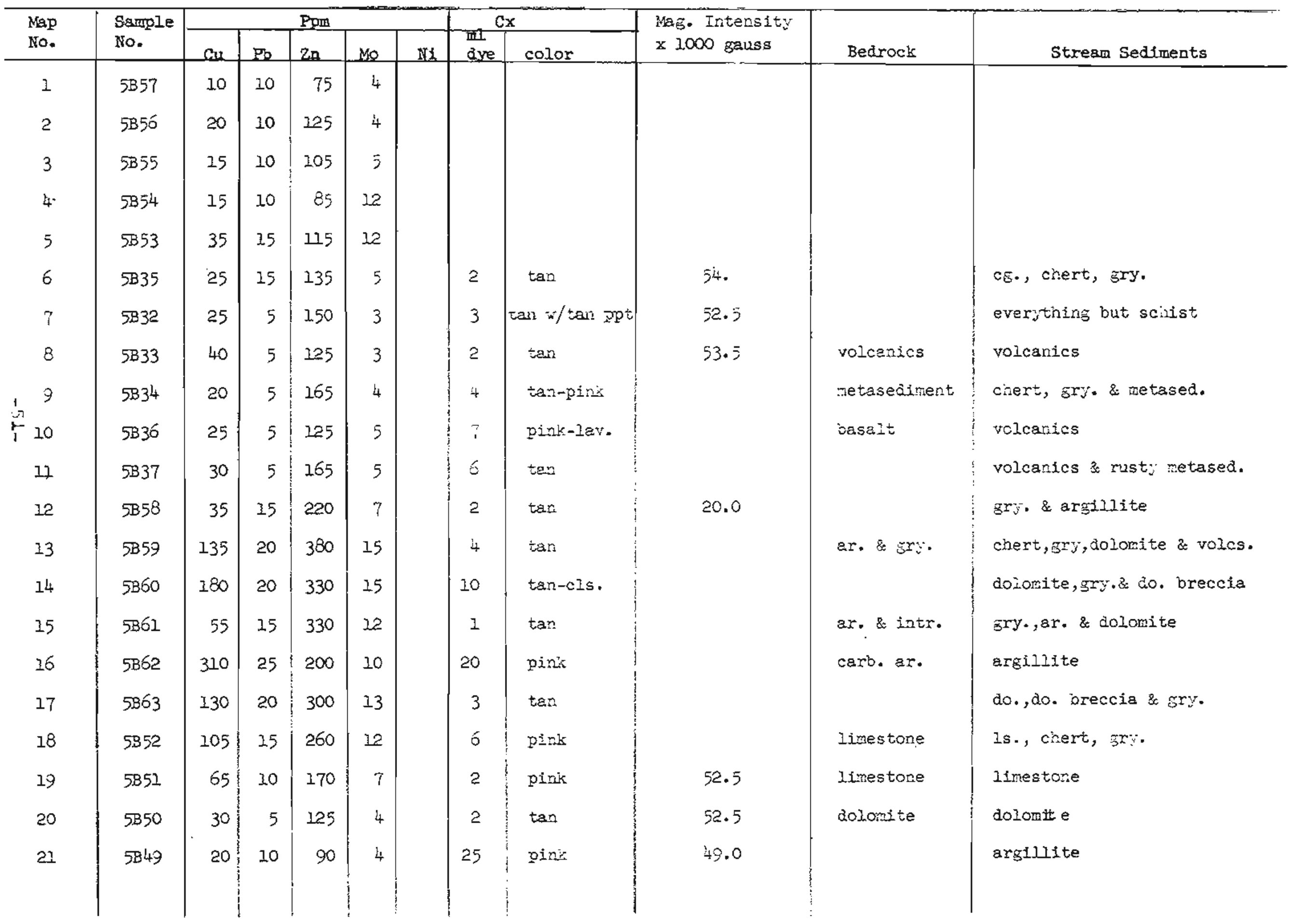




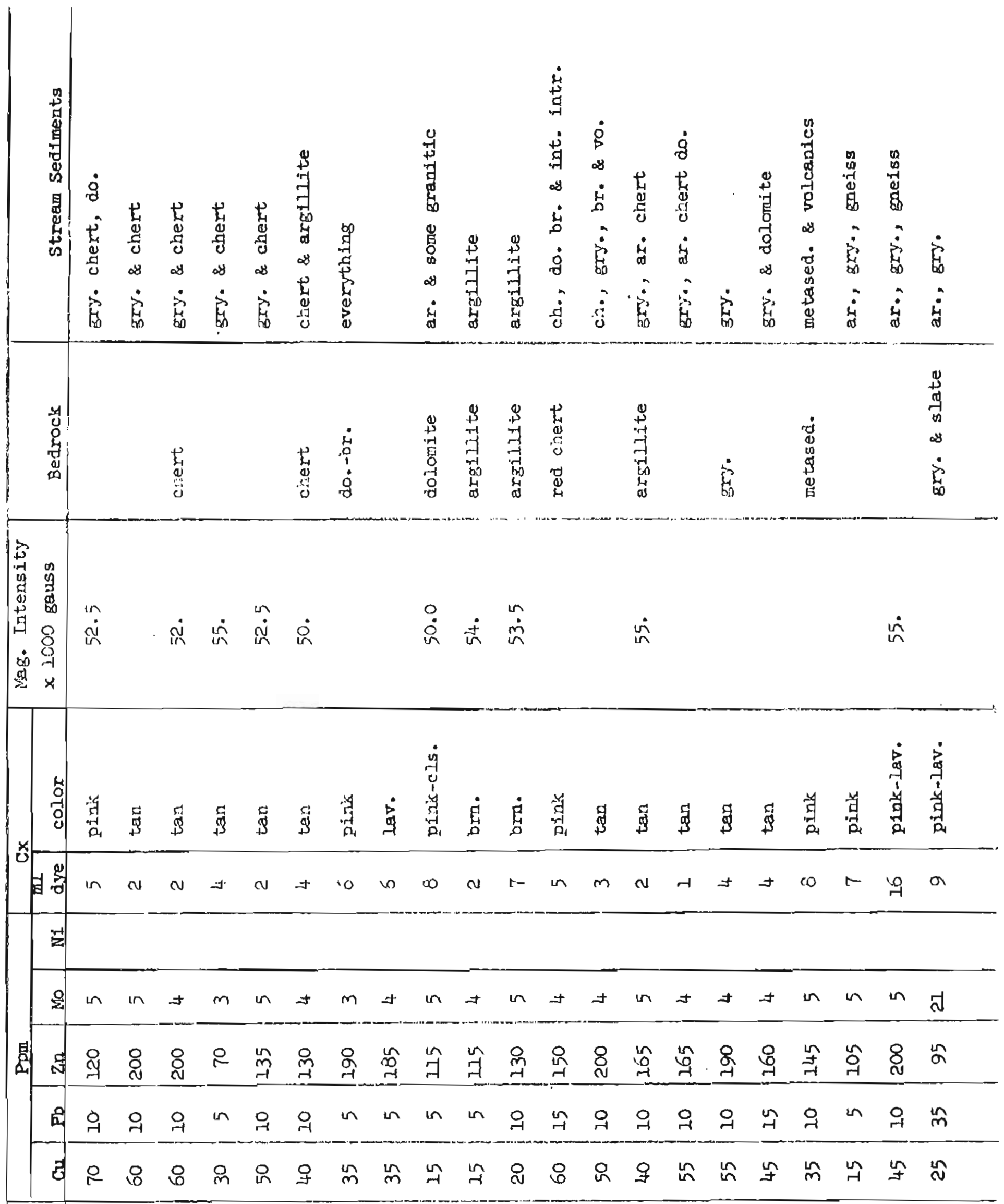

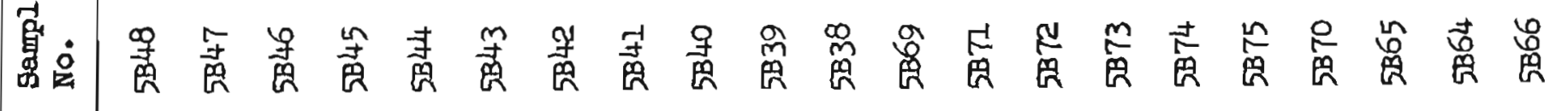

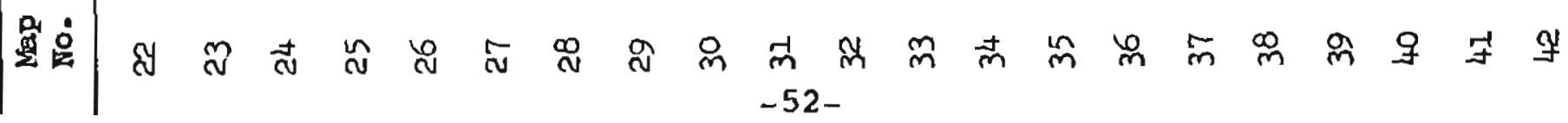




\begin{tabular}{|c|c|c|c|c|c|c|c|c|c|c|c|c|c|c|c|c|c|c|c|c|c|c|}
\hline & 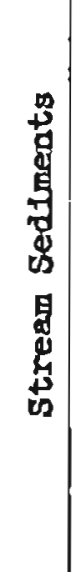 & 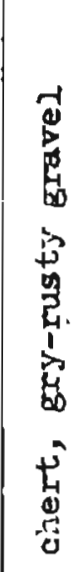 & 安 & 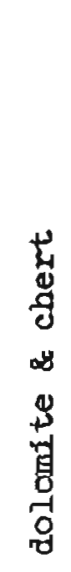 & $\begin{array}{l}\dot{8} \\
\dot{J} \\
\dot{j} \\
\dot{j} \\
\dot{d} \\
\dot{0}\end{array}$ & 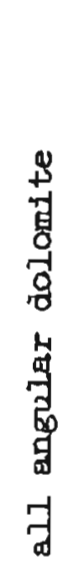 & 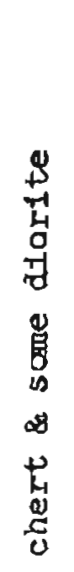 & 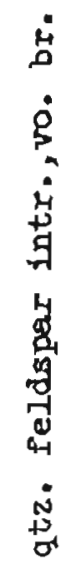 & 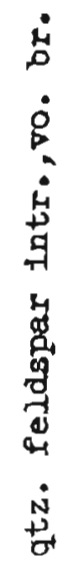 & 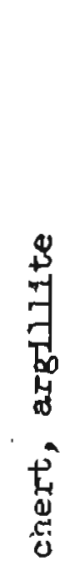 & 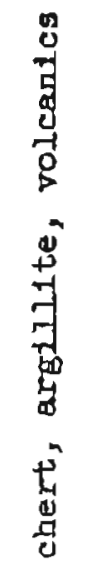 & 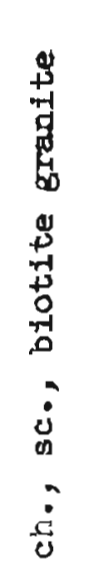 & 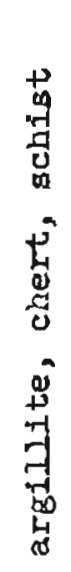 & 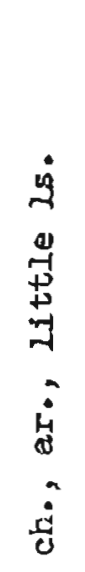 & 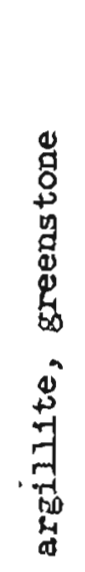 & 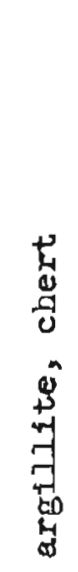 & 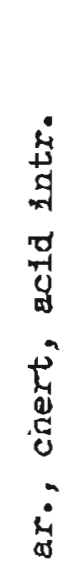 & 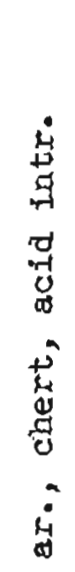 & 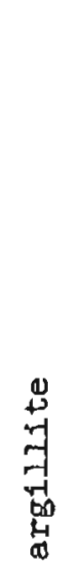 & 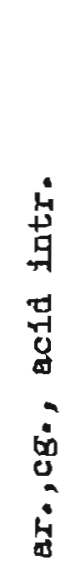 & 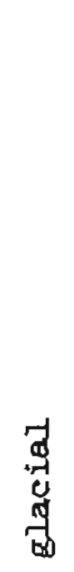 & 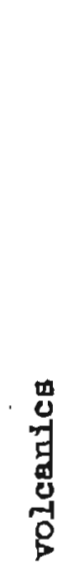 \\
\hline & 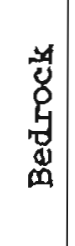 & & & 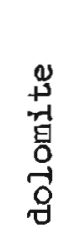 & & 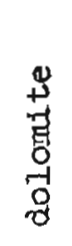 & & 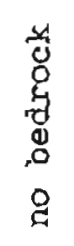 & 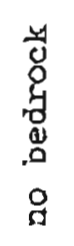 & 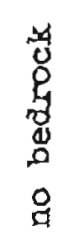 & 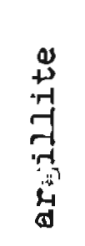 & 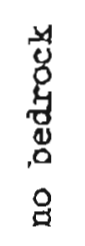 & $\begin{array}{l}0 \\
+3 \\
+7 \\
7 \\
7 \\
7 \\
80 \\
4 \\
0\end{array}$ & 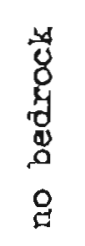 & 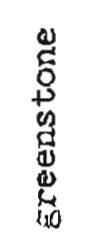 & 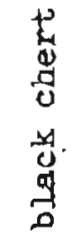 & 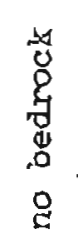 & $\begin{array}{l}y \\
0 \\
0 \\
y \\
0 \\
0 \\
0 \\
0\end{array}$ & 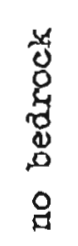 & 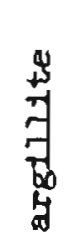 & 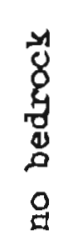 & 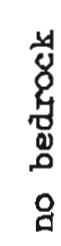 \\
\hline 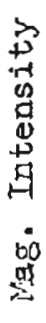 & $\begin{array}{l}\text { s } \\
\text { o } \\
\text { i } \\
8 \\
8 \\
8 \\
-1 \\
x\end{array}$ & & & & in & 它 & & & 崩 & $\begin{array}{l}\text { : } \\
\text { ज }\end{array}$ & & $\stackrel{0}{\dot{m}}$ & $\begin{array}{l}m \\
\text { in }\end{array}$ & $\underset{\dot{f}}{+}$ & $\begin{array}{l}\stackrel{v}{4} \\
\stackrel{f}{n}\end{array}$ & $\begin{array}{l}\infty \\
\dot{*} \\
\text { in }\end{array}$ & $\begin{array}{l}\infty \\
\dot{f} \\
\text { 足 }\end{array}$ & $\underset{\tilde{H}}{\tilde{H}}$ & 足 & $\underset{\dot{d}}{m}$ & & \\
\hline & $\begin{array}{l}0 \\
0 \\
0 \\
0 \\
0\end{array}$ & 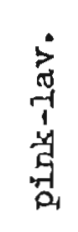 & 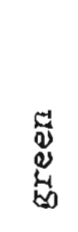 & 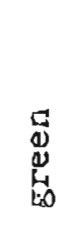 & $\begin{array}{l}\text { g } \\
y \\
0 \\
y \\
b\end{array}$ & 5 & $\begin{array}{l}\mathbb{Z} \\
\mathbb{d} \\
0 \\
4 \\
\text { bo }\end{array}$ & $\dot{\not ্}_{0}$ & 哥 & $\stackrel{9}{\$ 3}$ & & $\dot{B}$ & 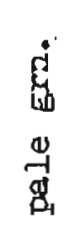 & 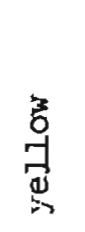 & 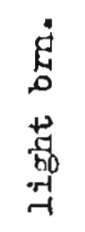 & & 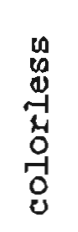 & 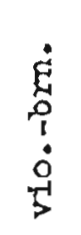 & & & & 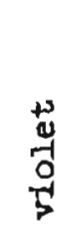 \\
\hline & 泡学 & $\infty$ & -1 & -1 & $r$ & in & -1 & $r$ & $\alpha$ & $m$ & 0 & in & $\alpha$ & $m$ & $\sim$ & 0 & $\rightarrow$ & in & 0 & 0 & 0 & + \\
\hline \multirow{4}{*}{ 圆 } & $\stackrel{0}{2}$ & n & in & $m$ & $\Rightarrow$ & co & $r$ & 0 & -1 & 0 & 0 & -1 & $d$ & 0 & $r$ & v & 0 & cu & 0 & 0 & 0 & $N$ \\
\hline & 只 & $\underset{7}{8}$ & $\stackrel{n}{n}$ & $\underset{\sim}{\mathbb{J}}$ & $\underset{-1}{8}$ & in & 곡 & $\underset{-1}{8}$ & $\stackrel{\operatorname{Ln}}{\alpha}$ & $\stackrel{\stackrel{m}{m}}{\rightarrow}$ & cy & 趿 & 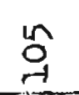 & $\begin{array}{l}\text { sn } \\
\text { on }\end{array}$ & ๕̂y & 号 & in & 9 & 요 & 8 & in & 욱 \\
\hline & 영 & $\dot{0}$ & $\stackrel{\circ}{-1}$ & 옥 & 욱 & 욱 & in & $\stackrel{\mathscr{n}}{\sim}$ & \& & \& & $\stackrel{\circ}{\rightarrow}$ & $\stackrel{n}{\mathrm{~N}}$ & 엄 & $\stackrel{n}{N}$ & 8 & nd & $\stackrel{u}{a}$ & cn & O & 象 & 욱 & 욱 \\
\hline & 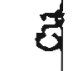 & 9 & 9 & $\stackrel{n}{m}$ & 을 & 8 & $\stackrel{n}{n}$ & $\tilde{a}$ & $\stackrel{\mathfrak{s}}{\mathrm{s}}$ & 음 & $\mathfrak{N}$ & $\stackrel{m}{ }$ & $\stackrel{i n}{m}$ & m & 而 & $\stackrel{\text { nf }}{\exists}$ & $\stackrel{n}{n}$ & $n$ & in & $\stackrel{n}{a}$ & 욱 & $\ddot{n}$ \\
\hline
\end{tabular}

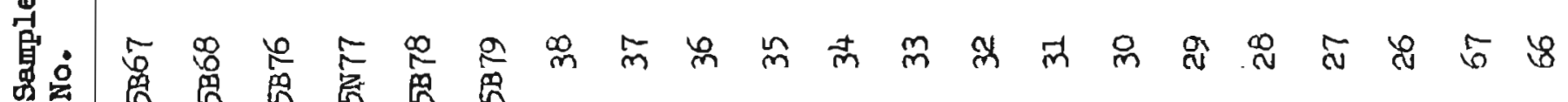

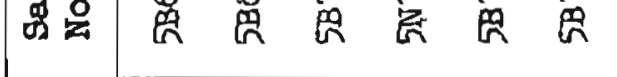

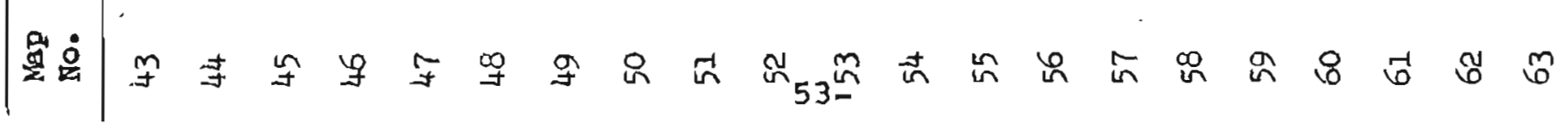




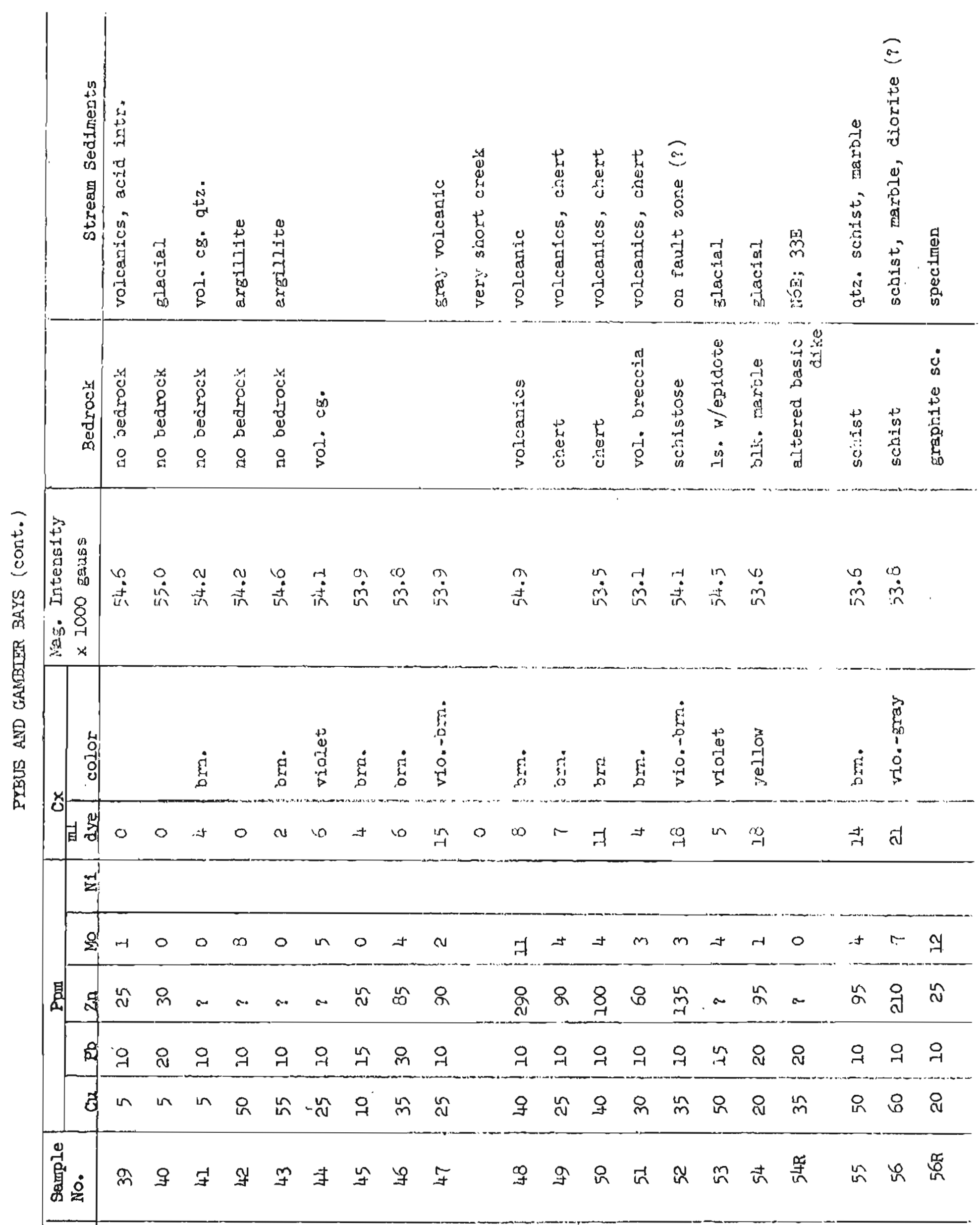

露 $\begin{aligned} & 0 \\ & 0\end{aligned}$ 


\begin{tabular}{|l|l|l}
$\mid$ \\
\hline
\end{tabular}




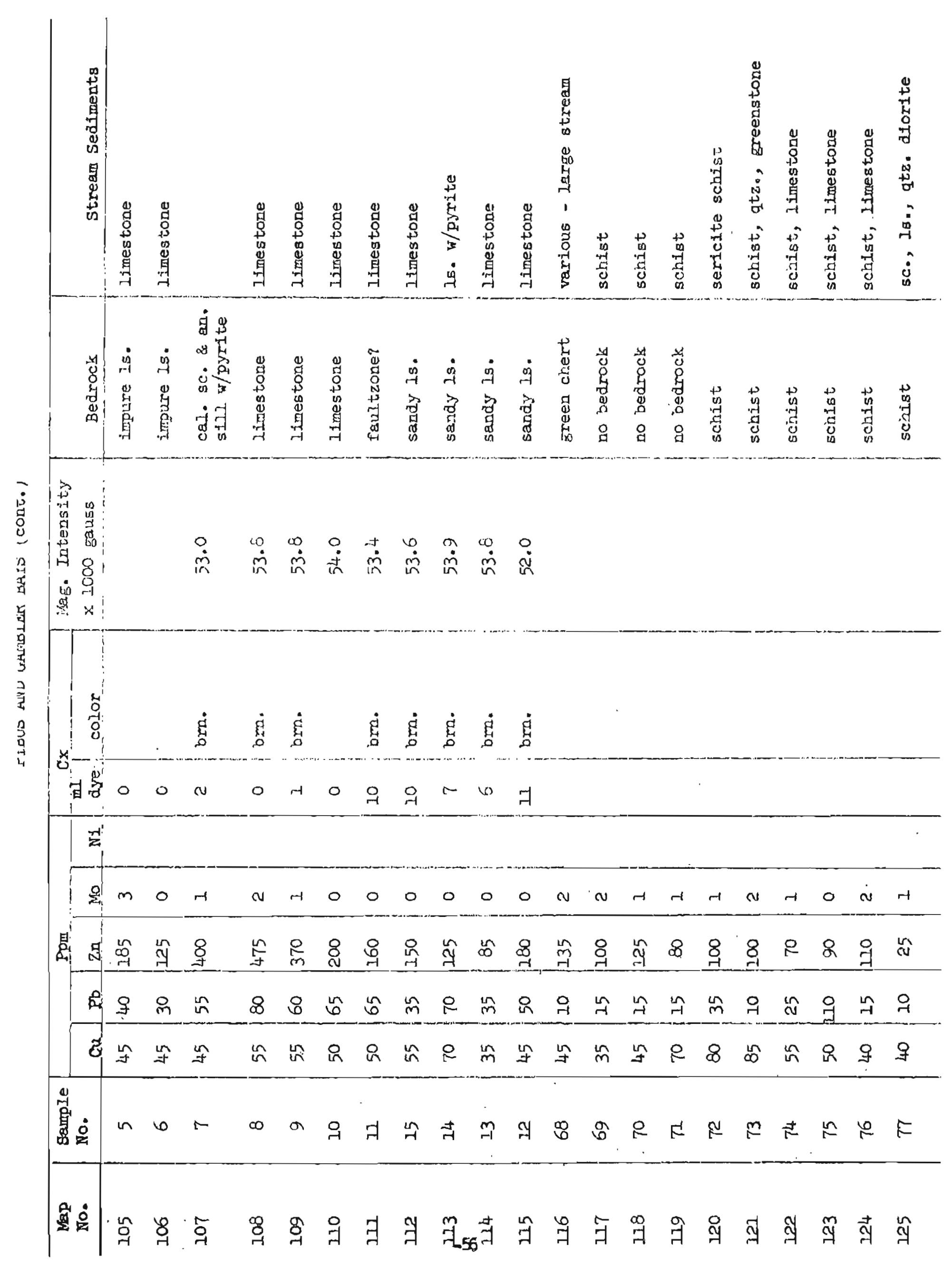




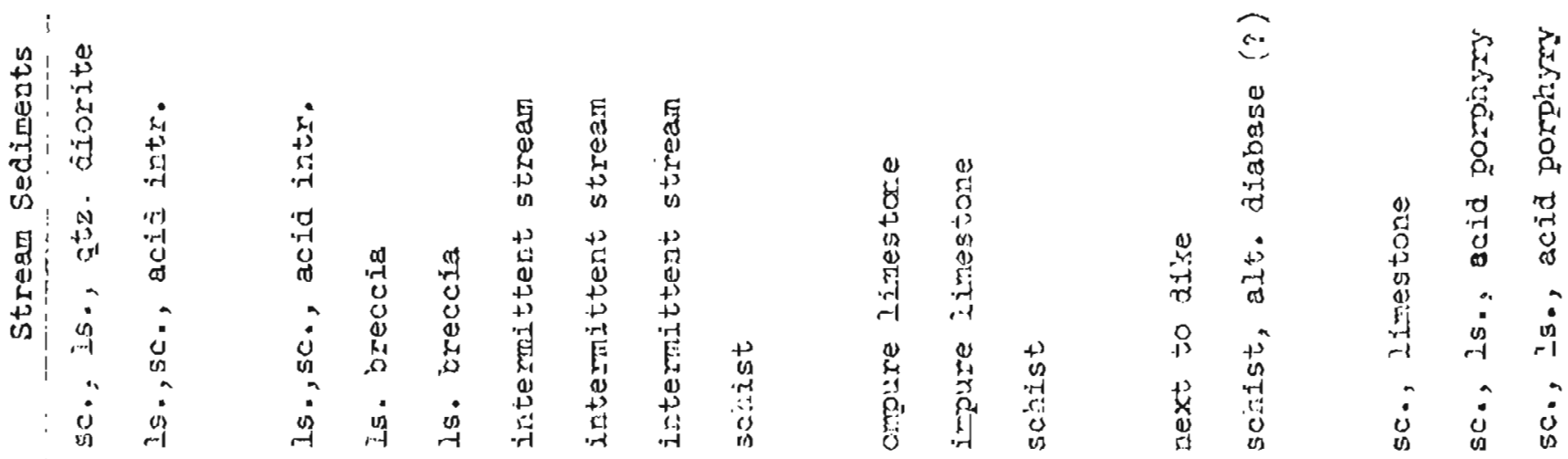

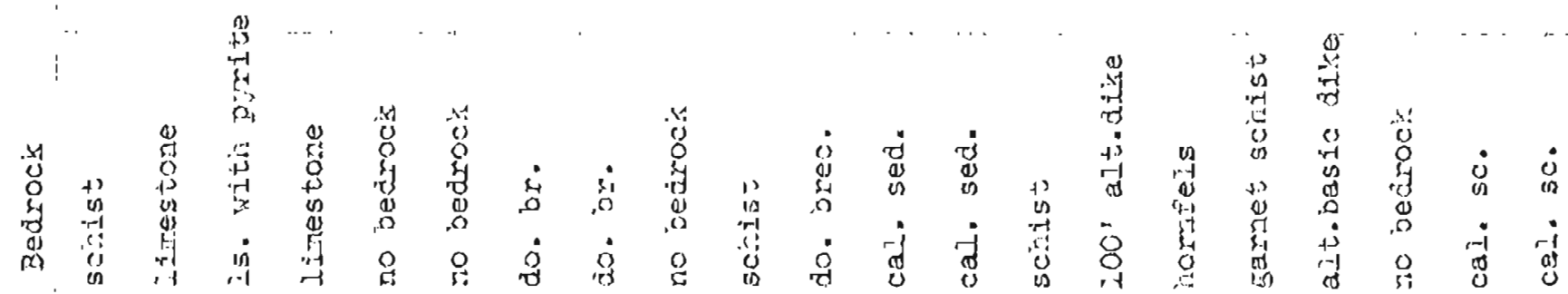

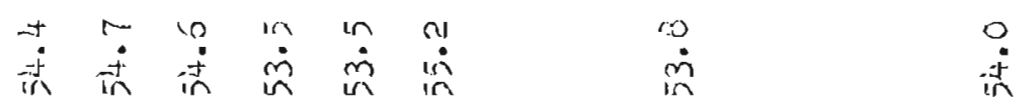

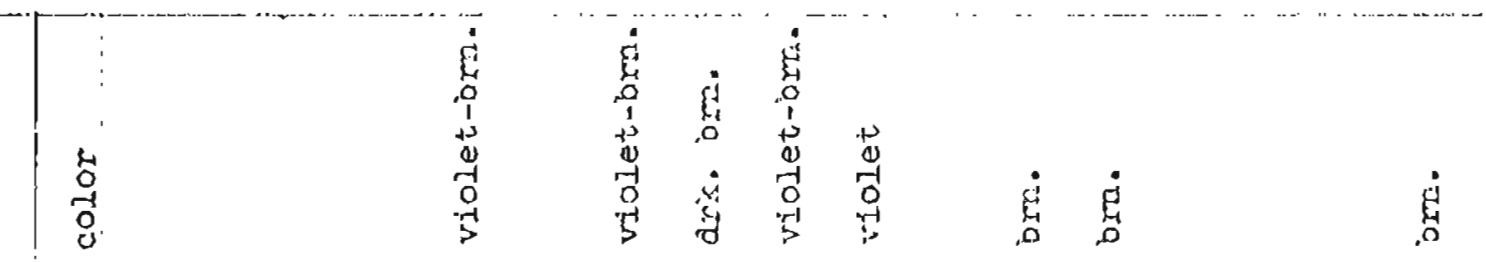

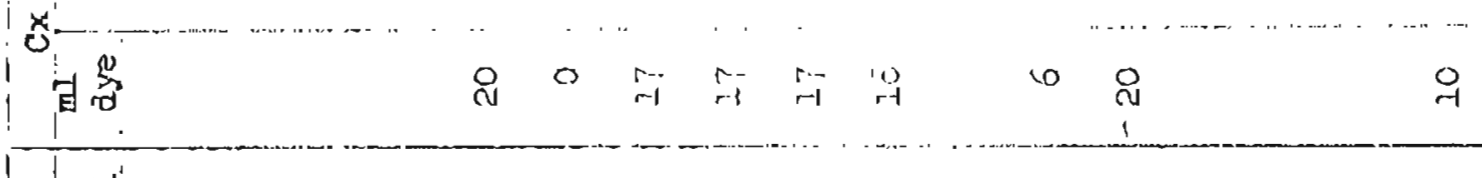

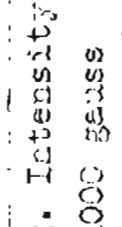

20.

as is

int

1 i

息

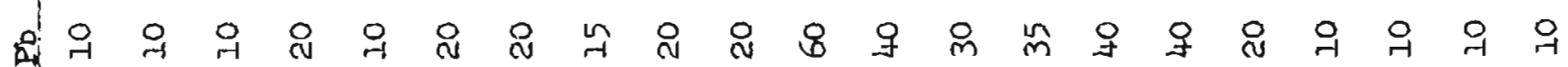

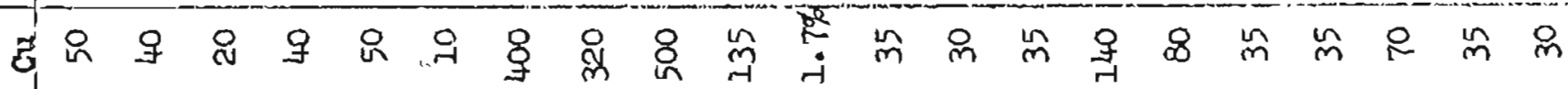

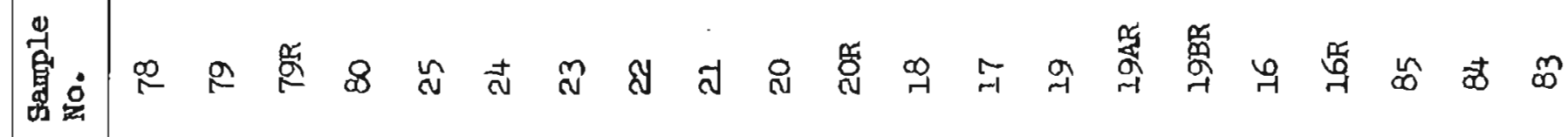

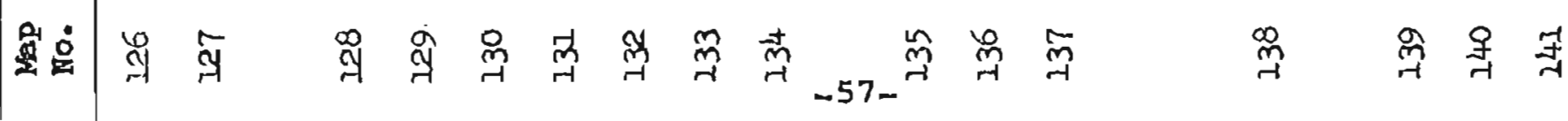




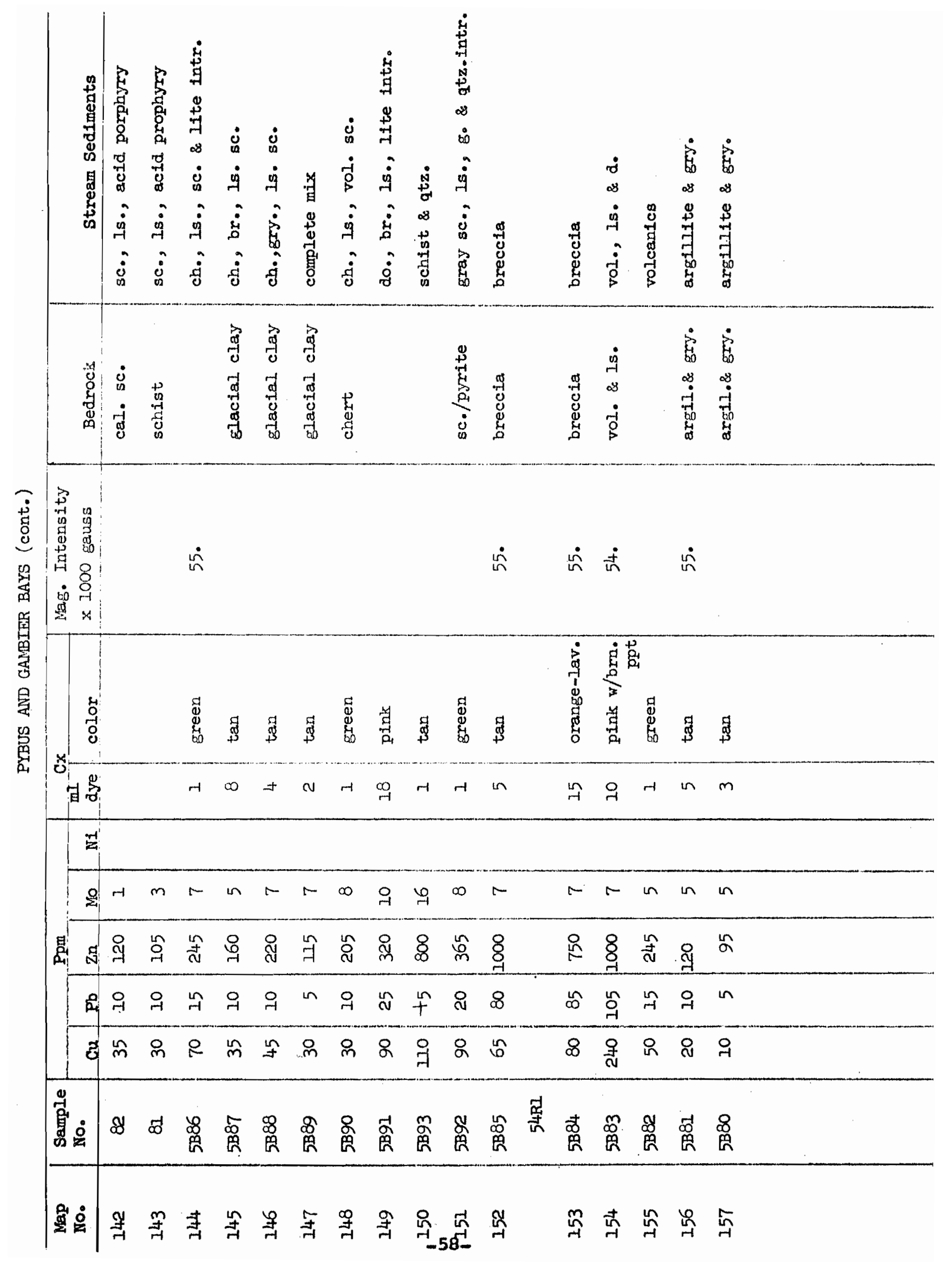




\section{STIKINE RIVER}

Eleven stream sediment samples were taken on June 18 and 19, 1964 between the Canadian border and the mouth of the stikine River, northeast of Wrangell. The area covered includes part of the Coast Range batholith and the bordering metamorphic rocks on its west side.

There are no known prospects in this area although the garnetiferous schist near Garnet ledge has been investigated as a possible source of industrial garnets.

None of the stream sediment samples showed what 15 considered an anomalously high metal content. 


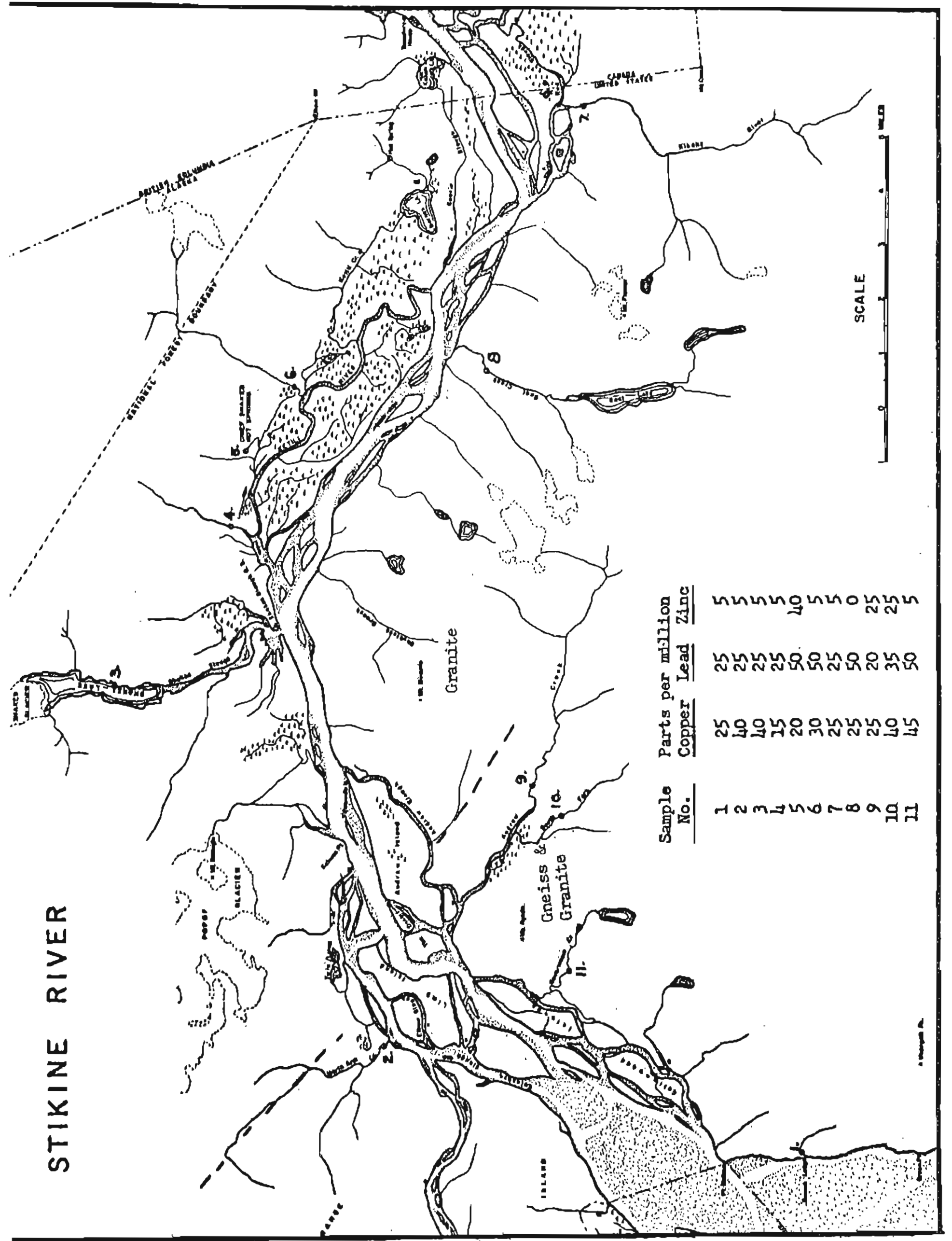


RATZ HARBOR - COFEMAN COVE

Ratz Harbor and Coffman Cove are located on the east side of Prince of Wales Island. Ratz Harbor is approximately 50 miles northwest of Ketchikan, and Coffman Cove is north of Ratz Harbor.

Keil and Peterman Corporation have constructed about thirty miles of logging road in the area for the Ketchikan Pulp Company. The logging road in that area has expoged bedrock in many places at Ratz Harbor, but in only a few places at Coffman Cove. Snow above the 500 foot level limited the sampling program at Ratz Harbor. Field work there was done in 1964 and at Coffman Cove in 1965.

\section{Geology}

The geology of Prince of Wales Island, and in particular the Kasaan Peninsula, has been described in the following U.S. Geological Survey Bulletins: Bulletin 347, "The Ketchikan and Wrangell Mining Districts, Alaska"; Bulletin 800, "Geology and Mineral Deposits of Southeastern Alaska"; Bulletin 1058-H, "Geology of Part of the Craig C-2 Quadrangle and Adjoining Areas, Prince of Wales Island, Southeast Alaska"; Bulletin 1090. "Iron and Copper Deposits of Kasaan Peninsula. Prince of Wales Island, Southeastern Alaska"; and Bulletin 1108-B, "Geology of the Craig Quadrangle, Alaska:".

Bulletin 1108-B shows the inland area of Ratz Harbor to be diorite, while the points on either side of the Harbor entrance are mapped as graywacke, slate, and andesitic volcanic rocks. The area to the west of the diorite is mapped as undifferentiated intrusive rocks, determined by photo interpretation. The undifferentiated intrusive rocks may include complexes of the metamorphic rocks. The diorite was found to continue northward to Coffman cove. The graywacke, andesites, and volcanics border the intrusives along the east shore.

Mineralization in the area is predominantly pyrite. However, magnetite was found in a gabbro between Lictle Ratz and Ratz Harbors, and in andesite north of Luck Lake which is south of Coffman Cove. A sample of granodiorite east of Big lake assayed 0.03 percent copper.

Magnetometer readings taken at sample points were uniformly between 10,000 and 15,000 gammas except for the reading taken beIow the outlet of Luck Lake, where a reading of 5,000 gammas was noted, and near site 21 where 11,000 gammas was noted. These may reflect the boundary of the intrusive. 


\section{Mineral Deposits}

The only reported deposit in the area is the old McCullough prospect which is at an altitude of about 100' and about a mille west of Gold and Gallion Lagoon, a salt chuck connecting Barnes and sweetwater Lakes. This prospect is described in U.S. Geological survey Bulletins 642-B and 963-A. A report by J.C. Rhoehm, former Territorial Mining Engineer of the Territorial Department of Mines is available for copy from the Division of Mines and Minerals Office, Box 1391. Juneau, Alaska, 99801.

The deposit is a quartz-breccia vein containing pyrite and chalcopyrite. The vein is approximately vertical and has been explored by a shaft 61 feet deep and by several open cuts. The vein is about 10 feet wide, and outcrops over a distance of 350 feet.

Samples taken by Roehm and the Survey indicate 0.7 to 3.3 percent copper. The property at the time this report was witten was unclaimed.

\section{Geochemical Investigation}

Twenty-two stream sediment samples were taken adjacent to logging roads at Coffman Cove in the vicinity of Luck Lake and at the head of Sweetwater Lake. At Ratz Harber, 35 field tests wese made, ten of which were bagged for laboratory analysis.

In the coffman Cove area, there are copper anomalies at map locations 4, 11, and 14. The most interesting of these is sarnple 14 (190 ppm of copper), which is included in a mile-long portion of a dioritic intrusion that carries higher than average amounts of copper from map location 13 to map location 14. The somewhat higher than average amounts of zinc and molybdenum at map location 22 are worth mention because the sample was taken from a 50 foot wide strean that draing a large area on the western margin of an intrusive mass.

In Ratz Harbor, sample 4 is anomalous in copper and possibly in zinc, since $180 \mathrm{ppm}$ of zinc is rather high for a stream that drains an area underlain by igneous rocks. The stream at map location 4 drains a fairly large area. 


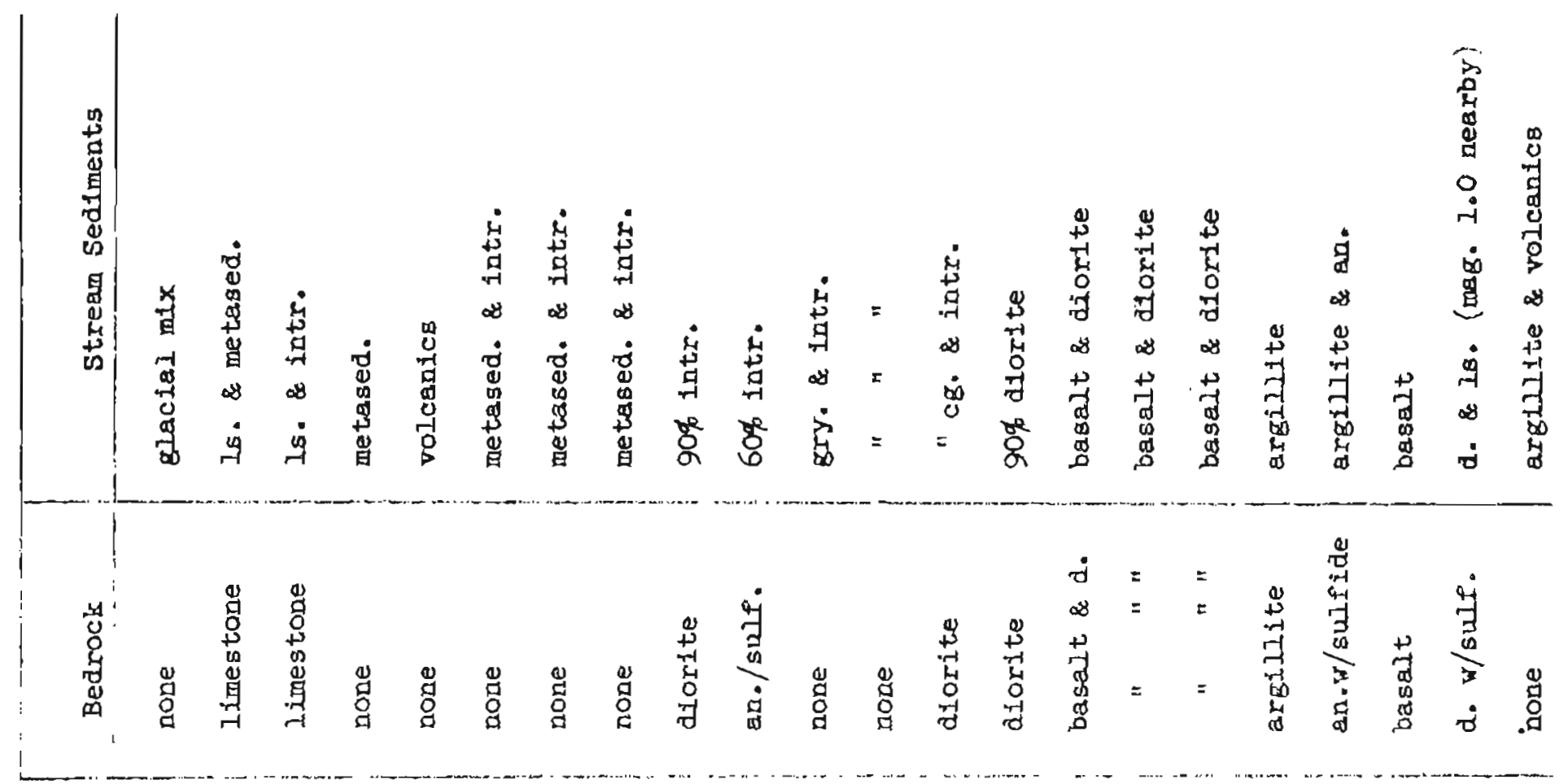

点

照些

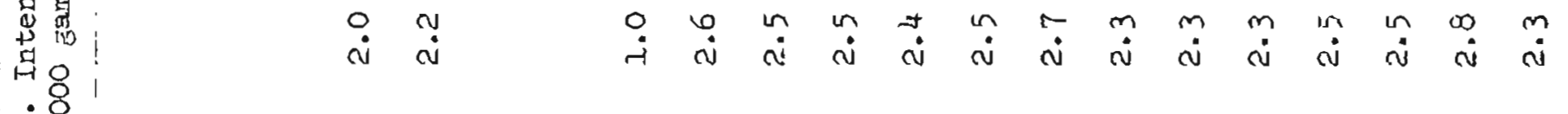

ㅁㅇㅇ

要 $x$

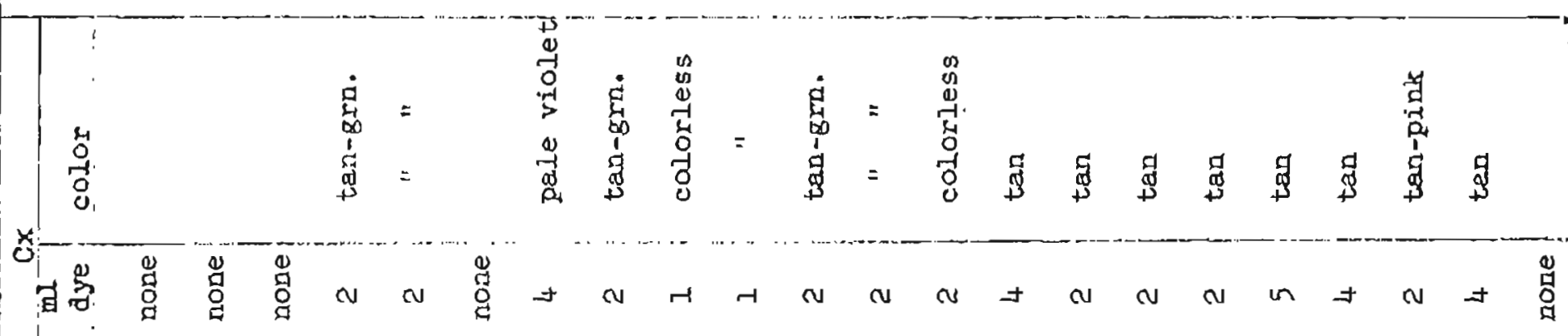

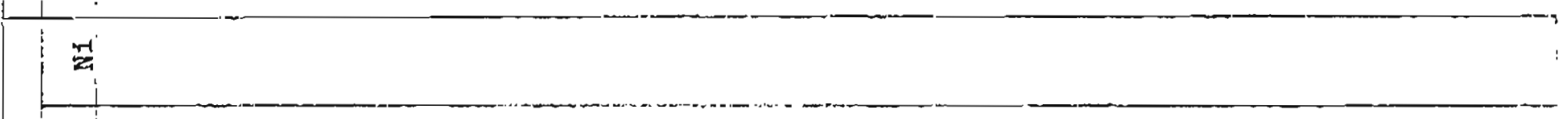

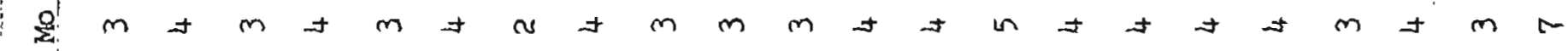

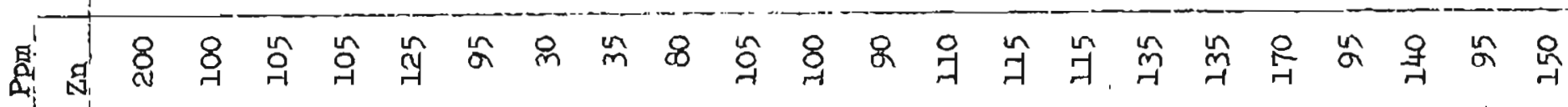

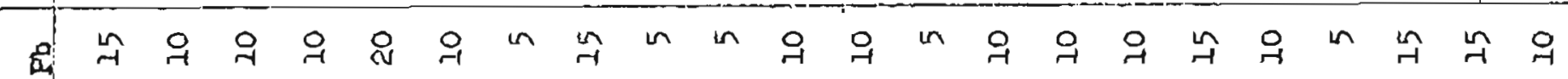

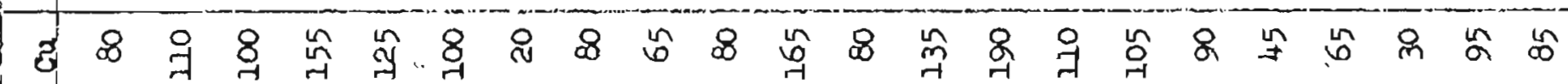

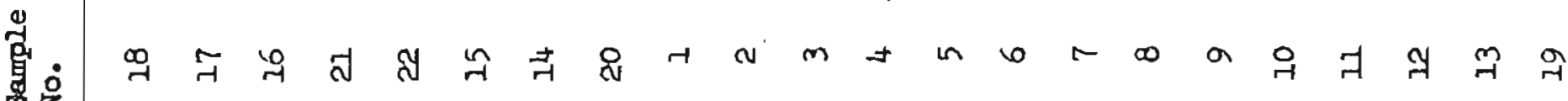
品总

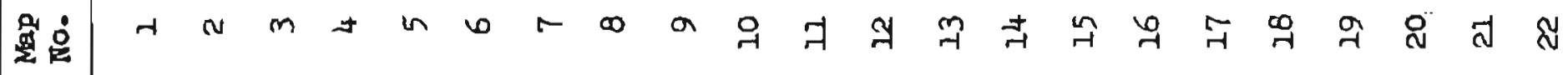
$-63-$ 


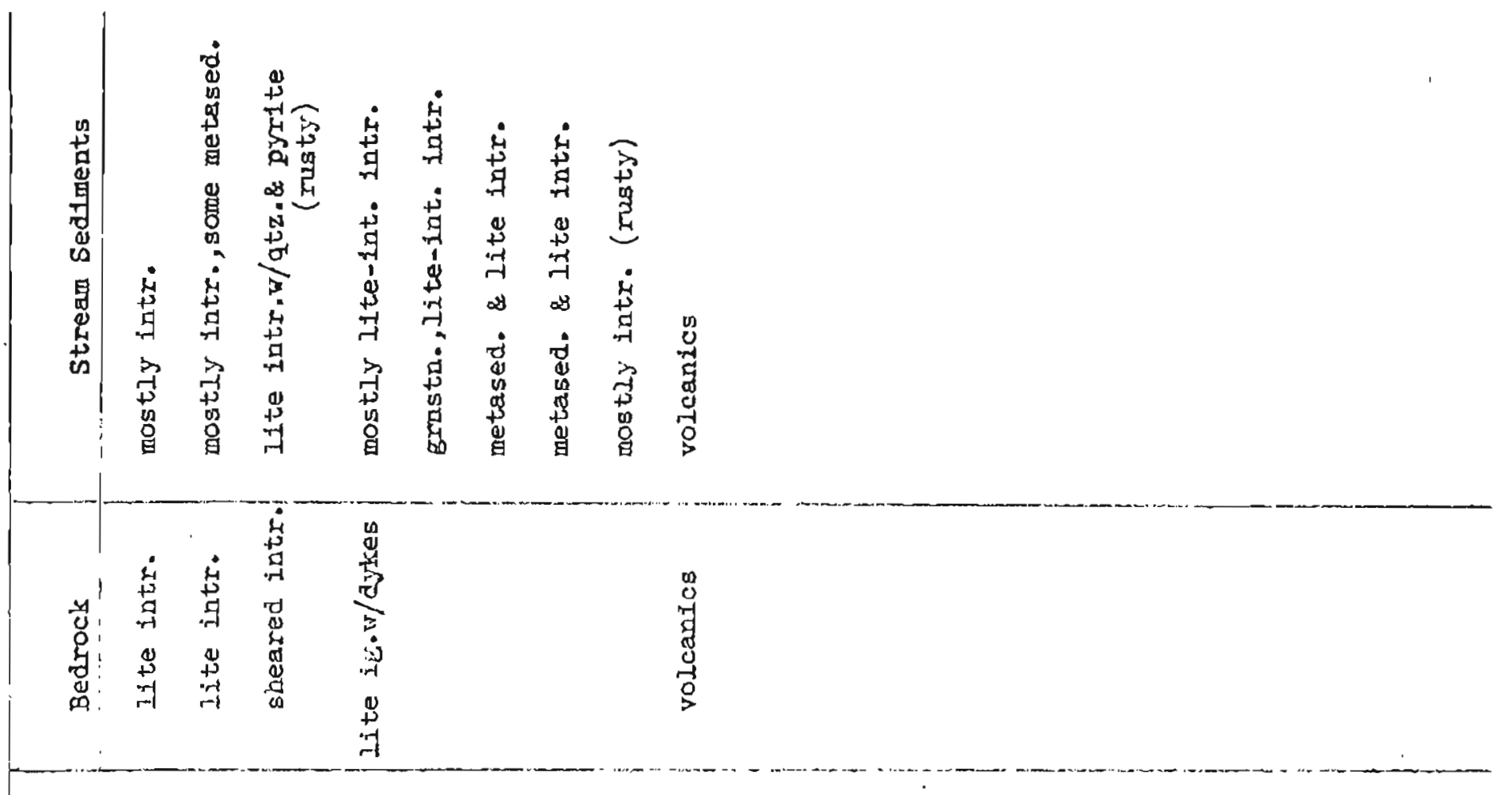$$
\text { . }
$$

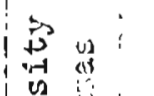

点

品

की

a

T

$\mid \begin{gathered}1 \\ 0 \\ 0 \\ 0 \\ 0\end{gathered}$

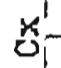

需学

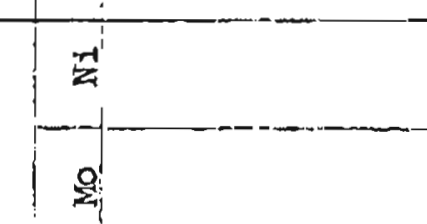

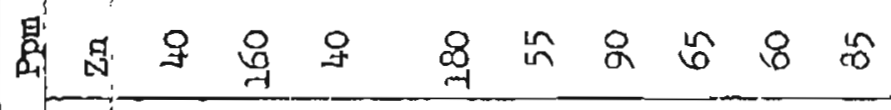

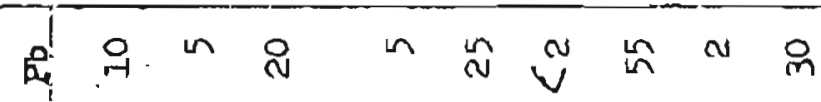

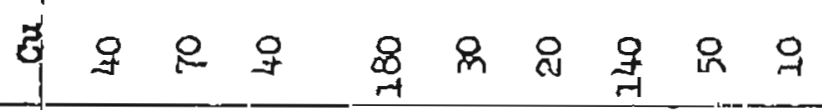

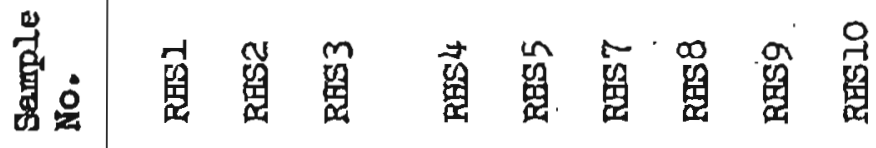

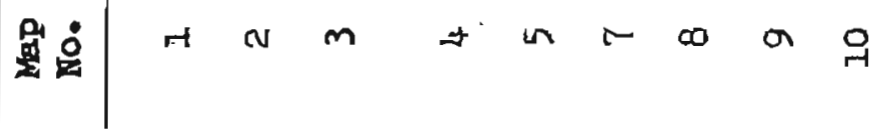




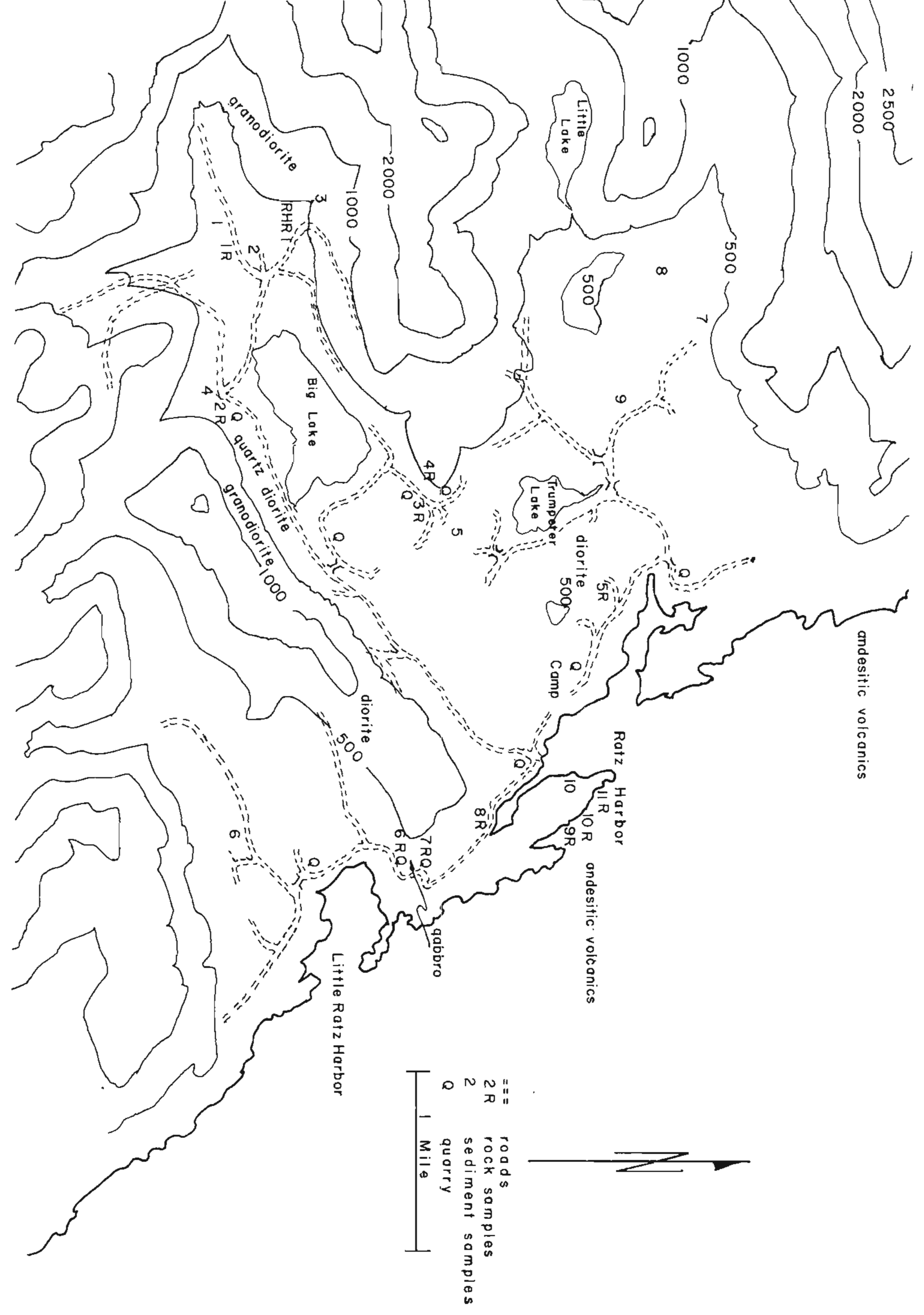




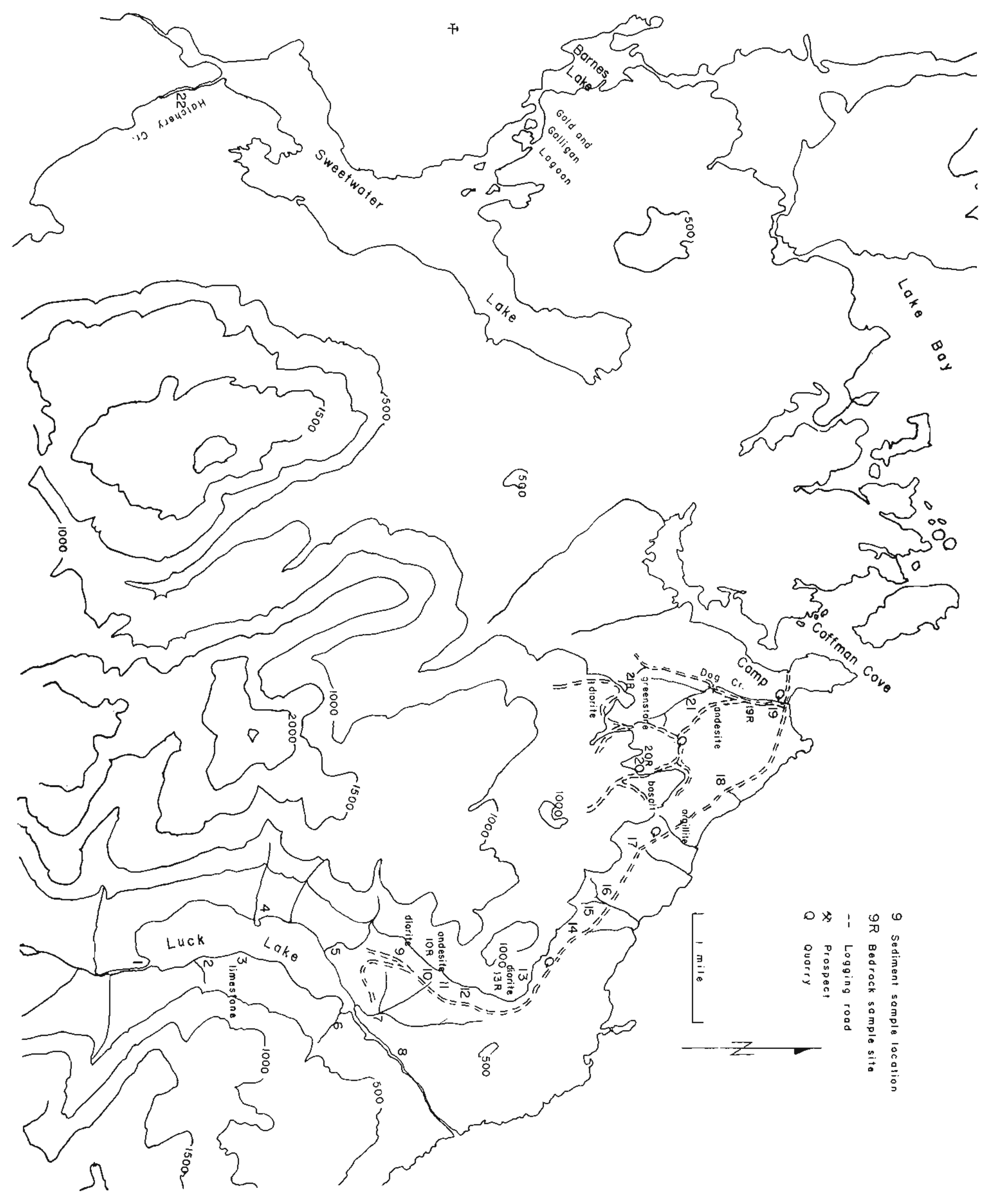


KINA COVE

Kina Cove is located approximately 5 miles ENE of Hollis. There are about six miles of logging roads south of the head of the bay. The area was logged about four years ago and has since grown to brush and young trees. system.

No reported prospects or mines exist in the vicinity of the road

\section{Geology}

The geology of Kina Cove is indicated by U.S. Geological survey Bulletin 1108-B to have been compiled from Bulletin 800 and "by photogeologic methods only". Bulletin 800, Plate $I$, shows the geology as consisting of Devonian sediments and lavas.

Bulletin 1058, "Geology of Part of the Craig C-2 Quadrangle and Adjoining Areas, Prince of Wales Island, Southeastern Alaska, Plate 33". shows part of Kina Cove as Silurian volcanic graywacke, conglomeratic volcanic graywacke, tuff, agglomerate, limy-matrix conglomerate, and lava flows too small to show on the map. This bulletin also shows the creek flowing through a unit of slate, slaty argillite, and minor fine conglomerate and graywacke, also of silurian age.

The field work confirmed that the slaty argillite includes graywacke and limestone near the beach and extends to the south end of the lake where it becomes quite schistose and contains a higher percentage of sulphides. The slaty argillite on the hill to the west of the lake shows evidence of crumbling and appears to be more graphitic than similar slaty arglilite near the mouth of Kina Creek.

\section{Geochemical Investigation}

Nine stream sediment samples were taken along the logging roads. These showed that the high zinc content in the Hollis area to the west peraistg into kina Cove. The high copper-zinc anomaly found at map location $4 \mathrm{is}$ interesting as is the molybdenum anomaly at map location 8 , which is apparently near an area with an unusually large amount of quartz. 
KIVA COVE

July 1964

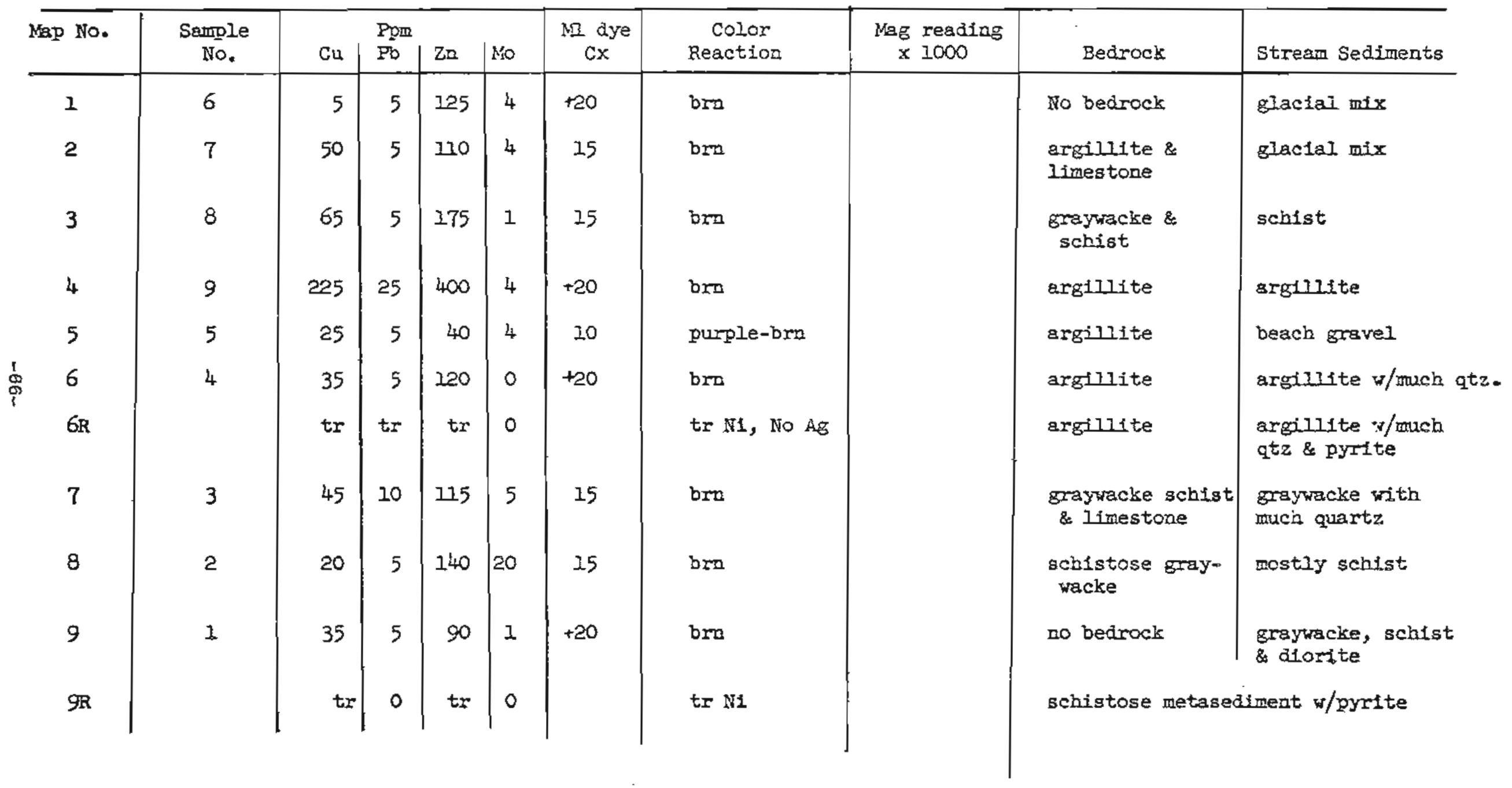


the
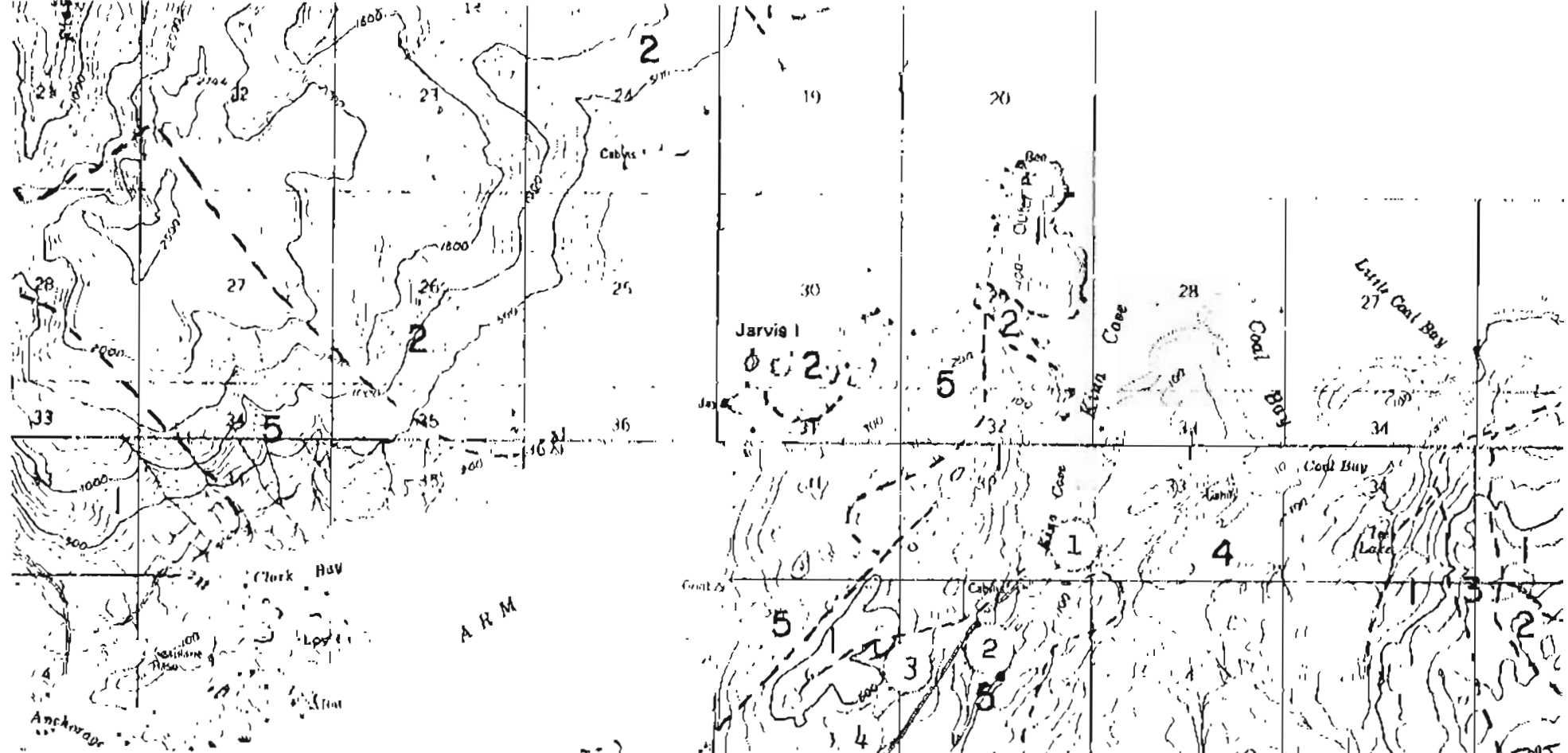

IIN

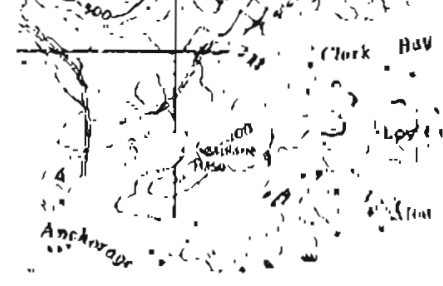

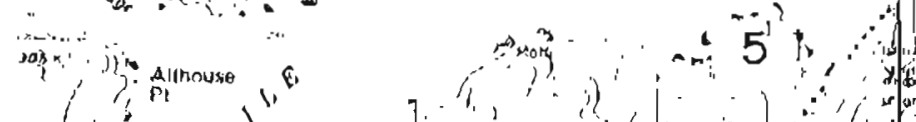
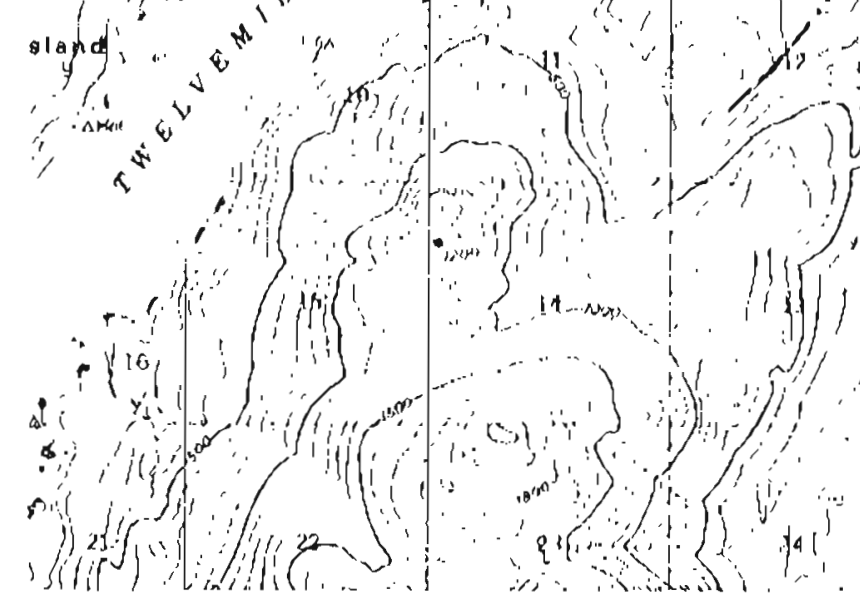

Geology from U.S.G.S. Bulletin 1058

1. Ordoviclan and Siluvian graywacke, tuff, conglomerate, and lavas

2. Cretaceous quartz diorite

3. Ordovician and S1lurian chert, argillite, and graywacke

4. Unconsolidated glaclal deposits

5. Ordoviclan and Silurian, blate, argililte, conglomerate and graywacke
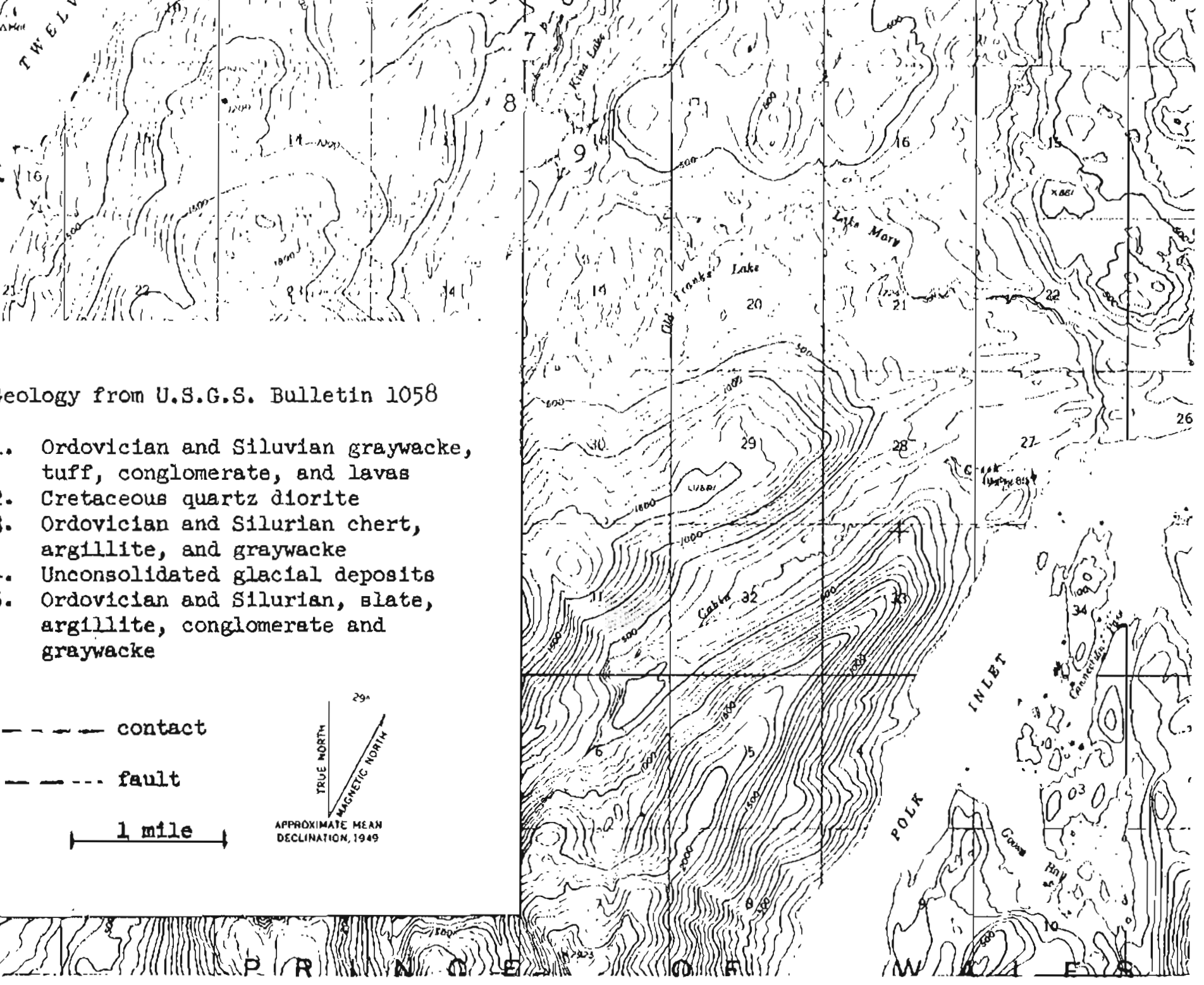


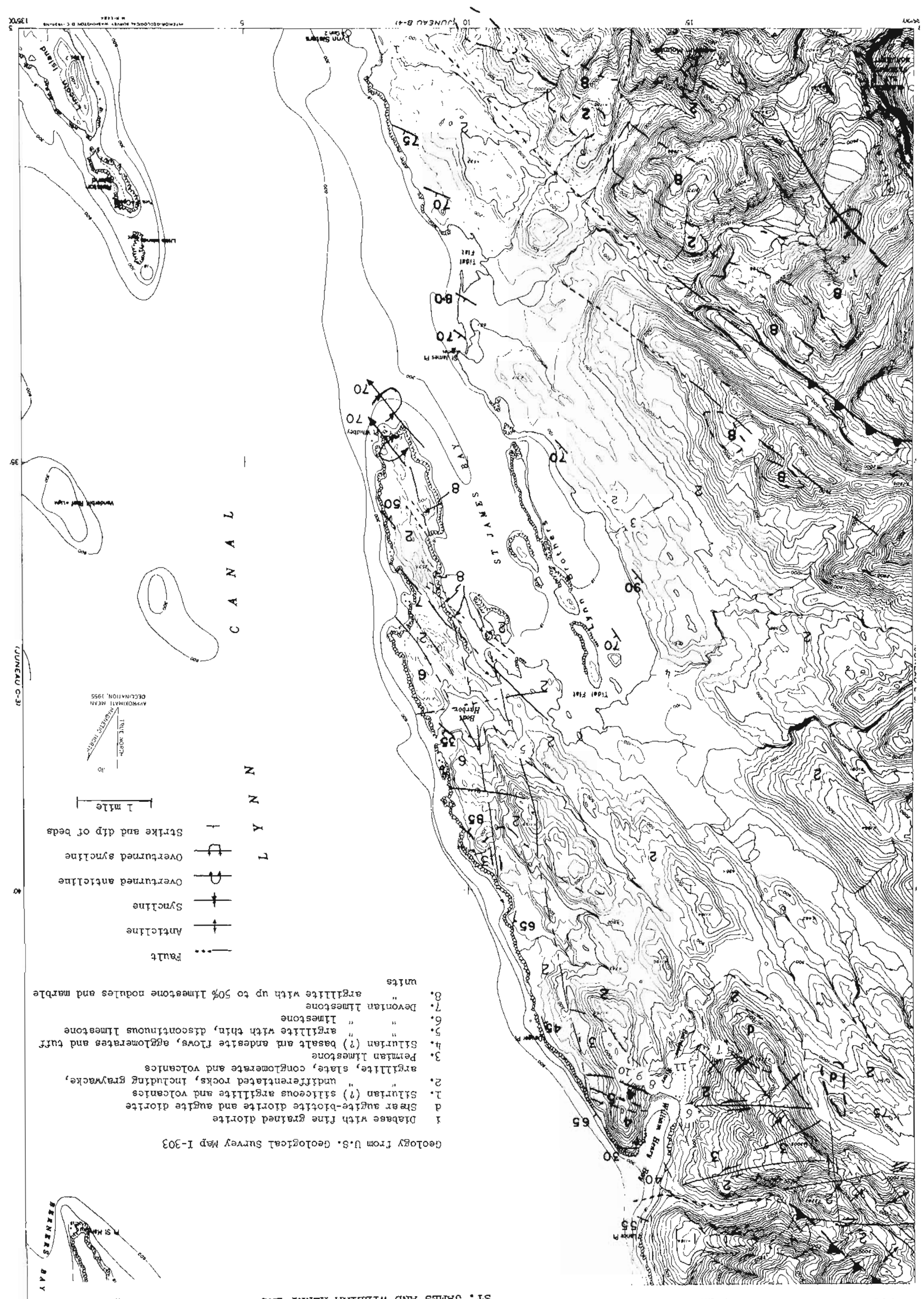

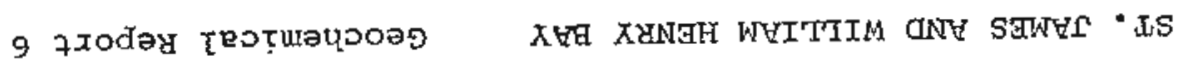

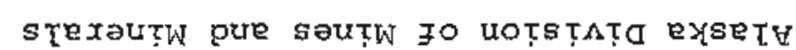

